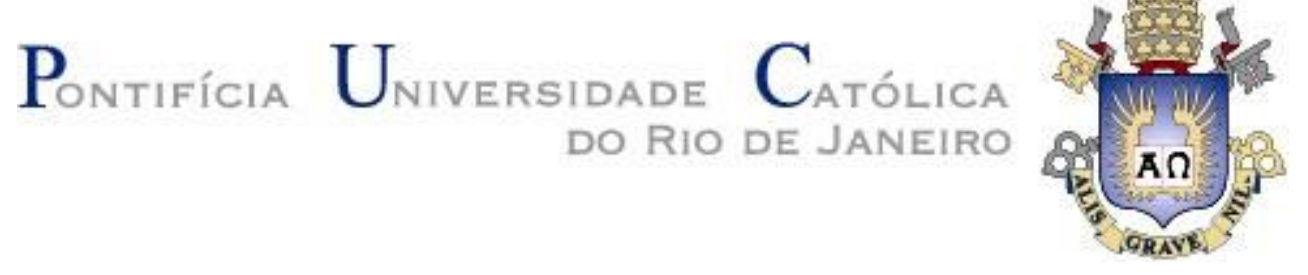

Ana Júlia Guinle de Mello

\title{
CONSIDERAÇÕES SOBRE O ESTATUTO DO CORPO NA ESTRUTURA CLÍNICA DA HISTERIA
}

\begin{abstract}
Dissertação de Mestrado
Dissertação apresentada como requisito parcial para obtenção do grau de Mestre pelo Programa de Pós-Graduação em Psicologia (Psicologia Clínica) do Departamento de Psicologia da PUC-Rio.
\end{abstract}

Orientadora: Prof ${ }^{a}$. Dr . Maria Isabel de Andrade Fortes 


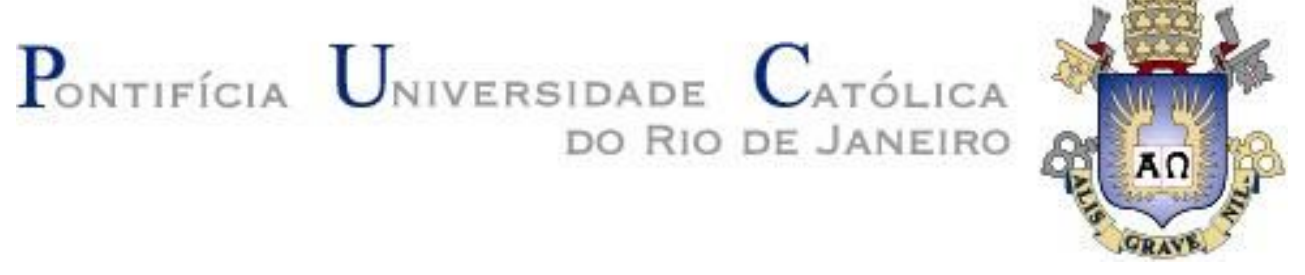

Ana Júlia Guinle de Mello

\section{CONSIDERAÇÕES SOBRE O ESTATUTO DO CORPO NA ESTRUTURA CLÍNICA DA HISTERIA}

Dissertação apresentada como requisito parcial para obtenção do grau de Mestre pelo Programa de Pós-Graduação em Psicologia (Psicologia Clínica) da PUC-Rio. Aprovada pela Comissão Examinadora abaixo.

Prof ${ }^{a}$. Drª. Maria Isabel de Andrade Fortes Orientadora Departamento de Psicologia - PUC-Rio

Prof. Dr. Marcus André Vieira Departamento de Psicologia - PUC-Rio

Prof. Dr. Edson Guimarães Saggese Universidade Federal do Rio de Janeiro

Rio de Janeiro, 29 de julho de 2021. 
Todos os direitos reservados. É proibida a reprodução total ou parcial do trabalho sem autorização da universidade, da autora e da orientadora.

\section{Ana Júlia Guinle de Mello}

Mestranda do Programa de Pós-Graduação em Psicologia Clínica, PUC-Rio.

Ficha Catalográfica

Mello, Ana Júlia Guinle de

Considerações sobre o estatuto do corpo na estrutura clínica da histeria / Ana Júlia Guinle de Mello ; orientadora: Maria Isabel de Andrade Fortes. 2021.

125 f. ; $30 \mathrm{~cm}$

Dissertação (mestrado)-Pontifícia Universidade Católica do Rio de Janeiro, Departamento de Psicologia, 2021.

Inclui bibliografia

1. Psicologia - Teses. 2. Histeria. 3. Sexualidade. 4. Imagem corporal. 5. Identificação. 6. Feminilidade. I. Fortes, Maria Isabel de Andrade. II. Pontifícia Universidade Católica do Rio de Janeiro. Departamento de Psicologia. III. Título. 


\section{Agradecimentos}

À Maria Isabel Fortes, por todos os ensinamentos durante o mestrado, pelas trocas, orientações e colocações tão substanciais para a construção da pesquisa e da escrita da dissertação. O estágio em docência também foi um marco durante essa trajetória, de aprendizados que levo comigo.

Ao Edson Saggese, por ser uma referência tão importante desde a pós do IPUB. A pesquisa do Proadolescer e os conhecimentos adquiridos nas orientações e nas supervisões foram imprescindíveis no meu percurso clínico e teórico.

Ao Marcus André, por todo o aprendizado, desde uma eletiva na graduação até a banca de qualificação do mestrado, na qual suas contribuições foram fundamentais e possibilitaram uma base importante para a escrita da dissertação.

À Renata Monteiro, pela escuta sensível e essencial durante essa trajetória. Por ter acompanhado minhas inquietações e reflexões suscitadas pela pesquisa. As leituras teóricas e a análise proporcionaram importantes caminhos internos.

À minha família, Daniela, Fábio, Luiz, Gê, Isa e Carol, por serem a minha base, meu chão e fonte de tanto amor. À Laurinha, que chegou para mudar a vida de todos nós, seu tamaninho sempre foi inversamente proporcional ao tamanho do amor que sentimos por você.

À Bel, pela certeza da nossa amizade, e isso é grande demais. Obrigada por todo apoio ao longo dessa trajetória, por fazer parte da minha vida em tantos âmbitos, verdadeira irmã que a vida me deu.

À Jú e à Jó, dividimos o mesmo nome e dividimos tudo o mais, obrigada pela amizade de tantos anos, pelas trocas e todo companheirismo. Vocês foram fundamentais nesse percurso, tanto pelas escutas sensíveis, pelas reflexões profundas quanto pelos encontros e momentos de descontração. 
À Ana Lu, que no momento mais difícil da escrita me fez pensar que seria possível continuar, aquelas trocas foram essenciais. Obrigada pela amizade tão verdadeira e por tudo que vivemos juntas.

À Luiza, pela amizade que se tornou tão fundamental, pelas trocas diárias, reflexões e tantas risadas. Pela potência que as nossas trocas proporcionam, são verdadeiramente transformadoras.

À Pilar, Ju, Paula e Olivia, pelas amizades tão fundamentais, pelas trocas, pelo apoio e pelas palavras de afeto e acolhimento sempre valiosas. À Ana Elisa, pela importância da nossa amizade em tantos momentos da minha vida.

Aos amigos do mestrado, Marina e Márcio, que se tornaram verdadeiros amigos para a vida. Sem vocês e a Bel, não sei como teria feito esse percurso acadêmico. À Beta, Rebeca e Mariana pelas trocas tão importantes.

Ao Leandro e ao nosso amor maior, obrigada por transformar minha vida e virar tudo de cabeça para baixo, pela intensidade, pelo carinho, pela poesia, pela confiança. Você mudou tudo.

À PUC-Rio, pelos auxílios concedidos, que viabilizaram a concretização desta pesquisa.

O presente trabalho foi realizado com apoio da Coordenação de Aperfeiçoamento de Pessoal de Nível Superior-Brasil (CAPES) - Código de Financiamento 001. 


\section{Resumo}

Mello, Ana Júlia Guinle de; Fortes, Maria Isabel de Andrade. Considerações sobre o estatuto do corpo na estrutura clínica da histeria. Rio de Janeiro, 2021. 125p. Dissertação de Mestrado Programa de Pós-Graduação em Psicologia Clínica, Pontifícia Universidade Católica do Rio de Janeiro.

A dissertação pretende refletir sobre a estrutura clínica da histeria, privilegiando o lugar que o corpo possui na formação da neurose histérica. Partese do pressuposto de que o corpo possui lugar privilegiado para a psicanálise, tendo sido através do encontro com as histéricas e de seu sofrimento inscrito no corpo por meio de ataques histéricos, sintomas conversivos e paralisias, que Freud pôde, na contramão do saber médico, construir a psicanálise. O eixo teórico desenvolvido no presente trabalho privilegia as contribuições de Freud e Lacan, baseando-se principalmente nos conceitos de sexualidade, imagem corporal, identificação e feminilidade, a fim de pensar o estatuto do corpo para a histeria. A reflexão sobre esses elementos permitiu verificar a problemática do corpo na origem psicossexual da neurose histérica e como local de formação de sintomas.

\section{Palavras-chave}

Histeria; sexualidade; imagem corporal; identificação; feminilidade. 


\section{Abstract}

Mello, Ana Júlia Guinle de; Fortes, Maria Isabel de Andrade (Advisor). Considerations on the status of the body in the clinical structure of hysteria. Rio de Janeiro, 2021. 125p. Dissertação de Mestrado - Programa de Pós-Graduação em Psicologia Clínica, Pontifícia Universidade Católica do Rio de Janeiro.

The dissertation intends to reflect on the clinical structure of hysteria, privileging the place that the body has in the formation of hysterical neurosis. It starts from the assumption that the body has a privileged place for psychoanalysis, having been through the encounter with hysterics and their suffering inscribed in the body through hysterical attacks, conversion symptoms and paralysis, that Freud was able, contrary to medical knowledge, to create psychoanalysis. The theoretical axis developed in this work privileges the contributions of Freud and Lacan, based mainly on the concepts of sexuality, body image, identification and femininity in order to think about the status of the body for hysteria. Reflection on these elements allowed us to verify the problem of the body in the psychosexual origin of hysterical neurosis and as a place of symptom formation.

\section{Keywords}

Hysteria; sexuality; body image; identification; femininity. 


\section{Sumário}

1 Introdução

p. 11

2 Histeria e sexualidade na teoria psicanalítica

p. 15

2.1 Primeiros marcos da etiologia da histeria: da lembrança do trauma à ab-reação

2.2 As relações simbólicas na histeria: o sintoma como símbolo mnêmico p. 19

2.3 Conversão somática e disponibilidade do corpo na histeria p. 23

2.4 O sexual traumático p. 25

2.5 Desenvolvimentos da teoria do trauma: o papel da sexualidade p. 28

2.6 Fantasias histéricas e bissexualidade p. 33

2.7 O sonho de injeção de Irma: o encontro com algo de inominável

3 Histeria, sexualidade infantil e imagem corporal p. 45

3.1 Sexualidade infantil e corpo erógeno p. 45

$3.2 \mathrm{O}$ conceito de pulsão em Freud e Lacan p. 53

3.3 O caso Dora p. 58

3.3.1 O caso Dora e a prevalência da oralidade p. 60

3.3.2 Uma pergunta acerca da feminilidade p. 63

3.3.3 A identificação no caso Dora p. 66

3.3.4 Os sonhos no caso Dora p. 69

3.4 A constituição da imagem do corpo p. 73

3.5 Imagem corporal e histeria p. 77

4 Corpo histérico, feminilidade e a questão fálica p. 80

4.1 O complexo de Édipo nos textos iniciais de Freud p. 80 4.2 A feminilidade em Freud p. 86

4.2.1 Tornar-se mulher em Freud p. 87 
4.2.2 Desdobramentos do feminino em Freud: a proposta de investigar como a mulher vem a ser ............................................ 95

4.3 A devastação e a questão histérica ......................................... p. 99

4.4 Histeria e relação com o corpo a partir do debate sobre o falo

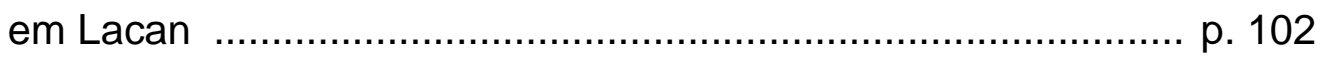

4.4.1 O corpo histérico e a questão fálica ..................................... p. 109

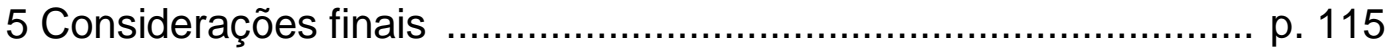

6 Referências ……................................................................ p. 117 
Ain't got no home, ain't got no shoes Ain't got no money, ain't got no class Ain't got no skirts, ain't got no sweaters Ain't got no perfume, ain't got no love Ain't got no faith

Ain't got no culture Ain't got no mother, ain't got no father Ain't got no brother, ain't got no children Ain't got no aunts, ain't got no uncles Ain't got no love, ain't got no mind

Then what have I got Why am I alive anyway? Yeah, hell What have I got Nobody can take away

I got my hair, got my head Got my brains, got my ears Got my eyes, got my nose

Got my mouth I got my I got myself

I got my arms, got my hands Got my fingers, got my legs

Got my feet, got my toes

Got my liver Got my blood.

Nina Simone (1968) 


\section{Introdução}

A estrutura clínica histérica refere-se a um quadro clássico da psicanálise, no qual se encontra o lugar do corpo como privilegiado. Apesar de a histeria ser conhecida por meio de sua teatralidade sintomática -os ataques histéricos, a conversão somática e as paralisias -, na qual o corpo configura-se como território para manifestação do sofrimento, o corpo surge também como origem psicossexual para o adoecimento histérico. Em outras palavras, o entrelaçamento do corpo com a histeria se dá de diferentes formas, extrapolando a perspectiva da expressão sintomática corporal.

Nesse sentido, o presente trabalho busca investigar, partindo dos Estudos sobre a histeria (Breuer \& Freud, 1893-1895/1996), como este entrelaçamento entre a neurose histérica e a problemática corporal vão sendo teorizadas por Freud, a partir da construção de conceitos fundamentais da psicanálise, tais como as definições do trauma, a noção de sexualidade perverso-polimorfa, o narcisismo e a imagem corporal, o complexo de Édipo e a sexualidade feminina. Além disso, as contribuições e avanços teóricos de Jacques Lacan serão fundamentais para a compreensão deste quadro clínico, bem como do papel da corporeidade na etiologia da neurose.

Há, ao longo da obra de Freud, diferentes definições do quadro clínico histérico, assim como pontos de apoio distintos para um diagnóstico diferencial. Em um primeiro momento, tendo a sintomatologia histérica maior relevo nos textos freudianos, Freud aponta o caráter de transposição de um afeto psíquico para o somático como o que caracterizaria a histeria. Em um segundo momento, o autor aponta o afeto de repulsa como o traço determinante para a detecção de uma neurose histérica. Além disso, outros fatores também são referidos pelo autor como importantes traços da histeria, como, por exemplo, a presença de um discurso do sujeito repleto de lacunas e não linear.

Estes elementos descritos, tais quais a transposição do psíquico para o somático, a repulsa e a lacuna são exemplares de diferentes pontos de partida utilizados por Freud para maior compreensão deste quadro clínico. No primeiro 
capítulo, estes pontos serão desenvolvidos mais profundamente, sendo justamente palco das discussões realizadas por Freud nos seus primeiros escritos.

O primeiro capítulo, portanto, terá como enfoque as questões trazidas por Freud acerca da histeria nos textos pré-psicanalíticos, escritos antes de 1900. Estas formulações iniciais trazem aspectos verdadeiramente ricos e singulares acerca da histeria, tendo algumas destas preciosas discussões iniciais perdido espaço para outras ao longo da obra do autor.

Assim, a capacidade de transposição do afeto psíquico em somático aponta para os sintomas corporais da histeria. Sobre estes, Freud vai formular a determinação simbólica e sexual do sintoma histérico. Com relação à primeira, Freud aponta a concepção do sintoma histérico como um símbolo mnêmico, trazendo a importância da relação da linguagem com o corpo histérico. Freud se refere a como a histeria possui o caráter de restaurar o significado originário das palavras, que se expressa nos sintomas, assim como aponta para a possibilidade de desfazer a dor do sintoma histérico a partir da fala nos atendimentos com as pacientes. Com relação ao fator sexual do sintoma, Freud afirma que este consiste em uma substituição da satisfação autoerótica praticada no passado. Além disso, sublinha a natureza do sintoma como realização de uma fantasia inconsciente.

Os traços de repulsa e de lacuna apontam para o que será desenvolvido no trabalho como uma perspectiva freudiana de investigação que privilegia a ausência de representação como origem da histeria. Esta perspectiva é apresentada pelo autor no Rascunho $K$ (1950[1896]/1996b), no qual indica uma "lacuna psíquica" no bojo da etiologia da histeria. O sonho da injeção de Irma (1900/19961) será abordado a fim de marcar o encontro de Freud com este inominável, como pontua Lacan. Estas noções, contudo, não serão retomadas ao longo da obra de Freud, tendo outras ganhado maior relevo.

Observaremos, assim, a presença de dois eixos nos primeiros escritos de Freud e ao longo de sua obra: um que aborda o conflito entre representações incompatíveis e outro que traz um enfoque ao que tem a ver com a excitação, à intensidade e ao excedente, à presença ou ausência de nexos de significação aos quais esta possa se ligar - o traumático (Alonso \& Fuks, 2012).

No segundo capítulo, trataremos dos conceitos de sexualidade perversopolimorfa e de narcisismo e constituição da imagem corporal, a fim de correlacioná-los com a neurose histérica. Além disso, abordaremos o caso Dora 
(Freud, 1905[1901]/2016) focando especialmente em dois pontos: a prevalência da oralidade em seus sintomas e a problemática da identificação.

A noção de sexualidade infantil nos auxiliará na compreensão da histeria, uma vez que aponta para um corpo erógeno, de desejo e representado pelas pulsões sexuais. Apontaremos como Lacan (1964/2008a) afirma que, nestes pontos de zonas erógenas, pode ocorrer uma queda da sexualização, que se apresentam nos fenômenos histéricos de desgosto; além disso, como Freud (1905/1996m) afirma que a histeria possui um contraditório enigma, pois se constitui por uma exacerbada necessidade sexual, ao mesmo tempo em que há intensa rejeição da sexualidade.

A oralidade no caso Dora contribuirá para a reflexão acerca de como a oralidade pode aparecer nos sintomas corporais -, tais como dispneia, afonia e tosse nervosa -, e também se apresentar como zona erógena privilegiada desde a infância, na qual Dora vive uma cena com o irmão que constituiu a matriz imaginária em que vieram a se depositar as situações que desenvolveu na vida (Lacan, 1951/1998b). Além disso, este caso é característico de como a histeria se constitui através de uma pergunta sobre "o que é uma mulher?", tendo esta questão envolvido Dora em uma trama identificatória, na qual uma figura feminina, a Sra. K., se apresentou como um mistério para Dora a respeito de sua própria feminilidade e de sua feminilidade corporal.

Assim, apontaremos o que aparece como uma falha no processo identificatório na histeria, que traz repercussões à constituição de sua imagem corporal. A falha identificatória da histeria diz respeito à falta de apoio encontrada no pai para uma identificação feminina, assim, à falha à nível da identificação simbólica fornecida pelo pai, corresponde uma falha à nível da imagem corporal e um correspondente despedaçamento anatômico enquanto fantasmático, que se revela nos sintomas corporais da histérica.

Por fim, com o objetivo de desenvolver a questão corporal da histeria, tornar-se-á necessário abordar o tema da feminilidade. No terceiro capítulo, abordaremos o complexo de Édipo em Freud e em Lacan. Destacaremos as concepções freudianas de pré-Édipo feminino e a compreensão da ligação ao pai como um fenômeno secundário em relação à ligação primordial da menina com a mãe. A problemática da identificação com o pai ganhará relevo, uma vez que há uma impossibilidade do pai de transmitir um significante que lhe forneça uma 
referência identificatória. Diante disso, trataremos da saída que a histérica encontra, segundo a qual ela, ao se deparar com a ausência de um suporte fálico, faliciza seu corpo, faz-se "toda fálica”, tornando seu corpo identificado ao falo.

Buscamos, com esta pesquisa, contribuir para o conhecimento teórico e clínico da psicanálise, uma vez que a estrutura clínica da histeria permanece atual, apesar de não possuir os mesmos sintomas característicos do período em que Freud teorizou sobre este tema e construiu a psicanálise. Nasio (1991) aponta como o sofrimento da histeria atualmente aparece sob faces mais discretas e menos espetaculares do que as do final do século XIX e início do século XX. Freud (1923/2011b) faz alusão às mudanças nas roupagens dos sintomas neuróticos, afirmando que as neuroses de tempos passados assumiam determinadas roupagens, ao passo que, naquele contexto, "nossa pouca psicológica época atual", disfarçavam-se de enfermidades orgânicas.

Nesse sentido, o presente trabalho teve como ponto de partida a clínica, e um encontro com problemáticas relacionadas ao corpo, que tomaram a cena de múltiplos atendimentos. Diante disso, um estudo sobre a relação do sujeito com o corpo tornou-se substancial e, com isso, estudar a estrutura clínica da histeria surgiu como um caminho fundamental para uma maior compreensão do lugar do corpo como origem e expressão do sofrimento psiconeurótico. 


\section{2 Histeria e sexualidade na teoria psicanalítica}

No presente capítulo, abordaremos os primeiros escritos de Freud acerca da histeria, baseando-nos principalmente no desenvolvimento inicial da teoria do trauma, na determinação simbólica e sexual dos sintomas corporais e na articulação entre a noção de lacuna psíquica referida por Freud no Rascunho $K$ (1950[1896]/1996b) e nas contribuições presentes no relato do sonho da injeção de Irma (1900/19961). Neste capítulo enfatizaremos a presença de duas perspectivas teóricas utilizadas por Freud para a investigação do fenômeno histérico: uma que privilegia o conflito entre representações irreconciliáveis e outra que aborda a excitação, o excedente que aponta para o caráter traumático das vivências.

Vislumbrar-se-á também os desdobramentos que o papel do sexual ganha ao longo destes primeiros escritos de Freud. Inicialmente, o sexual tem um lugar que podemos caracterizar como ambíguo, sendo referido como algo excessivo, provocado por um fator externo, que se coloca como um corpo estranho no psiquismo (Freud, 1893/1996a), ao passo que, em 1895, têm-se, enfim, a correlação entre o trauma e o caráter sexual de uma experiência (Breuer \& Freud, 1893-1895/1996). Além disso, outros desdobramentos sobre o sexual serão abordados, como, por exemplo, no caso do relato do sonho da injeção de Irma (1900/19961), no qual se pode observar uma primeira apreensão inovadora a respeito do sexual, qual seja, a noção do sexual como uma função de suspensão de sentido (Teixeira, 2010). Veremos como estas contribuições servirão para uma maior compreensão do estatuto do corpo na histeria.

\section{1 \\ Primeiros marcos da etiologia da histeria: da lembrança do trauma à ab-reação}

Estudos sobre a histeria (Breuer \& Freud, 1893-1895/1996) é considerado um livro emblemático do período pré-psicanalítico, no qual se pode rastrear os primeiros passos para a elaboração dos pilares da psicanálise. Nele, Freud, em conjunto com Breuer, buscam elucidar os mecanismos psíquicos por trás dos 
sintomas histéricos, assim como estabelecer a sua etiologia, formulando os germes das primeiras teorizações a respeito da neurose histérica, que a eles se apresentava na clínica do final do século XIX.

A teoria inicial sustentada por trás do método catártico é considerada prépsicanalítica, uma vez que o marco do advento da psicanálise é tido como o surgimento da hipótese do inconsciente. As elaborações teóricas neste primeiro momento admitiam ideias inconscientes que se expressavam no sintoma, contudo, estas ideias eram consideradas presentes apenas em casos patológicos (Rudge, 2009).

$\mathrm{Na}$ “Comunicação preliminar”, Breuer e Freud (1893-1895/1996) apresentam a etiologia da histeria a partir da noção de trauma. Expõem a hipótese de que a causa precipitante da histeria está relacionada a um evento traumático ocorrido na história de vida do paciente. Os autores são bastante categóricos ao afirmarem a exterioridade do trauma, ou seja, que "fatos externos determinam a patologia da histeria" (p. 39). Posteriormente, essa teoria inicial do trauma com base em um evento na realidade material sofrerá mudanças nas elaborações teóricas de Freud, dando lugar ao conceito de fantasia.

Mas, no contexto deste manuscrito realizado pelos dois autores, o trauma era concebido com base em um "fato de infância" (p. 40) e, posteriormente, um "trauma desencadeador" (p. 40) provoca o aparecimento da doença. Os autores destacam a desproporção de anos de duração entre os sintomas histéricos e o evento traumático. Os sintomas histéricos são descritos da seguinte forma: ataque histérico, nevralgia, anestesia, contraturas, paralisias, convulsões, perturbações de ordem dos tiques, vômitos crônicos e anorexia, perturbações da visão, dentre outros.

Neste ensaio, os autores apontam dois fatores desencadeantes da doença: o "trauma psíquico" e o que aponta para uma "relação simbólica". Neste último, o fato desencadeante pode ser encontrado no relato clínico do paciente de forma explícita. Assim, a conexão causal consiste em uma "relação 'simbólica' entre a causa precipitante e o fenômeno patológico" (p. 41); tal tipo de relação encontrase também nos sonhos. São casos de, por exemplo, sintomas de vômitos após um sentimento de repulsa moral.

O "trauma psíquico", por sua vez, ocorre com mais frequência e decorre de experiências que podem evocar afetos aflitivos, tais como susto, angústia, 
vergonha ou dor física. A suscetibilidade da pessoa afetada é fundamental para o evento se tornar traumático.

Percebe-se que, nesse momento, há uma separação entre as concepções de trauma psíquico e de "relação simbólica", o que será retomado mais a frente, conciliando a teoria do trauma e a questão da simbolização presente no sintoma histérico.

Seguindo as teorizações sobre o trauma psíquico, os autores compreendem que este não atua como um mero agente provocador na liberação do sintoma, pelo contrário, o trauma psíquico, mais precisamente a lembrança do trauma, atua como um "corpo estranho", funcionando como um agente que continua em ação no psiquismo após sua entrada.

Rudge (2009) enfatiza a importância de assinalar que o trauma psíquico não designava apenas uma experiência, mas o momento em que uma ideia se torna patogênica, ou seja, o momento em que houve a cisão psíquica com a consequente instauração de um corpo estranho no psiquismo.

Pollo (2016) pontua que esta compreensão da causalidade histérica como um "corpo estranho" atuando insistentemente no interior do indivíduo aponta para a necessidade da construção de um conceito limítrofe que remetesse, ao mesmo tempo, ao dentro e ao fora, ao corpo e ao estranho, necessidade esta que também se imporá posteriormente na construção do conceito de pulsão, conceito que desenvolveremos adiante.

Com efeito, neste período entre 1893 e 1895, o que se descobre é que o trauma se apresenta sob a forma de uma "lembrança do trauma" e continua a atuar durante anos, não apenas como uma corrente de elos causais intermediários, mas como uma causa diretamente liberadora, ocasionando os sintomas histéricos. Esta compreensão é sintetizada na célebre frase segundo a qual "a histérica sofre de reminiscências" (p. 43).

Aqui, podemos perceber a importância dada à lembrança do trauma, à representação do evento traumático, que, apesar da distância temporal do evento ao momento atual, continua ativa no psiquismo através de uma corrente de elos causais. Essa concepção permitirá a construção do método de tratamento baseado na rememoração do evento traumático, método este baseado na fala, a talking cure. 
Segue-se no texto a hipótese de por que a lembrança continua atuando no psiquismo: isto ocorre graças ao afeto que permanece vinculado a ela. Os autores observam que, quando não há uma reação à altura do evento, capaz de suscitar um afeto, a lembrança preserva sua tonalidade afetiva do início. Nas palavras dos autores: “essas lembranças correspondem a traumas que não foram suficientemente ab-reagidos" (Breuer \& Freud, 1893-1895/1996, p. 45).

A partir disso, percebe-se a importância, não só de trazer uma lembrança patogênica à consciência, mas também da ab-reação do afeto estrangulado, ou seja, de um afeto que foi contido devido à falta de reação do sujeito diante de um evento traumático.

Gostaríamos de adiantar que, ao longo das primeiras formulações de Freud, é possível perceber a descrição de dois eixos para uma compreensão do mecanismo da histeria: um que trata de um conflito entre representações e outro que se refere àquilo que tem a ver com a excitação, à intensidade, com o excedente e com a presença ou ausência de nexos de significação aos quais esta possa se ligar - o traumático (Alonso \& Fuks, 2012). Trata-se aqui de duas perspectivas que se desdobrarão no que Freud nomeou de concepção dinâmica e concepção econômica.

Assim, em 1894, no artigo Neuropsicoses de defesa, Freud dá prosseguimento às suas formulações, trazendo um enfoque à noção de conflito entre representações incompatíveis. $\mathrm{O}$ autor afirma que a histeria surge a partir de uma "ocorrência de incompatibilidade em sua vida representativa" (p. 55). Tratase de uma experiência, representação ou sentimento que suscita um afeto aflitivo ao Eu, que ocasiona o conflito psíquico.

Nesse manuscrito, Freud postula a noção de defesa, distanciando-se de Breuer e Janet ao discordar de suas teorias, de "estados hipnoides" e de divisão da consciência, respectivamente. Assim, segundo o autor, o processo de defesa se dá através da transformação efetuada pelo Eu da representação poderosa em uma representação fraca, destituindo-lhe do afeto, isto é, da soma de excitação, que carrega.

Segundo o psicanalista vienense, a soma de afeto desvinculada da representação apresenta uma particularidade na histeria, distinguindo-se dos processos que ocorrem na fobia e na obsessão. Desse modo, na histeria ocorre o que Freud denominou de conversão, isto é, o afastamento da representação e do 
afeto e a "transformação de sua soma de excitação em alguma coisa somática" (p. 56). O autor descreve o mecanismo da conversão como um fenômeno que opera sob a linha da inervação motora ou sensorial ligada à experiência traumática.

Assim, a neurose histérica possibilita que o ego se liberte da contradição, contudo, ao preço de se sobrecarregar com um símbolo mnêmico que se instala na consciência. O traço mnêmico da ideia recalcada não é dissolvido, formando o núcleo de um segundo grupo psíquico (Freud, 1894/1996i).

Freud (1894/1996i) apresenta a hipótese de que, na histeria, ocorre a formação de um núcleo para uma expulsão (splitting off) no momento traumático. Este núcleo cresce em outros momentos, quando novas impressões da mesma espécie conseguem uma ruptura na barreira erigida, suprindo a representação enfraquecida de um afeto renovado, e, assim, reestabelecendo provisoriamente o elo associativo entre os dois grupos psíquicos.

Em outras palavras, ocorre a constituição de um "grupo psíquico separado", formado a partir de representações que foram dissociadas e postas para fora da consciência. O sintoma, por sua vez, vem no lugar da lembrança que foi isolada. Alonso e Fuks (2012) observam que Freud, na busca de responder ao enigma dos esquecimentos das pacientes (esquecido, este, que está em algum lugar e gera efeitos), depara-se com o desejo e a defesa. São construtos teóricos que levarão, posteriormente, aos conceitos de inconsciente e de sexualidade infantil.

Nesse período inicial, entretanto, a noção de sexualidade ainda não estava delineada propriamente. A centralidade da tese de Freud se referia à incapacidade de ab-reagir, através da linguagem, a uma vivência de natureza sexual, a qual desenvolveria um trauma psíquico. Por enquanto, o que sobressai para o autor é a impossibilidade de o sujeito elaborar psiquicamente um evento experimentado de forma violenta. Uma vez que o sujeito não seja capaz de reagir à intensidade de uma experiência, verificar-se-á um trauma de natureza psíquica (Naves, 2007).

\section{2 \\ As relações simbólicas na histeria: o sintoma como símbolo mnêmico}

No início de sua prática clínica, por volta de 1885, Freud é convidado por Charcot para realizar um estudo comparativo das paralisias motoras orgânicas e 
histéricas - estudo este que será apenas publicado em 1893. Com isso, desde os primeiros trabalhos de Freud, e a partir das investigações a respeito da histeria, começa a ser delineada uma visão diferenciada do estatuto do corpo, que se configura como distinta do corpo biológico da medicina, por não ser regulada pelos mesmos estatutos e regras fundamentais. Assim, ao instituir a especificidade do corpo na histeria, Freud rompe com o discurso da medicina da época.

Nesse sentido, a descoberta de Freud não se refere apenas à constatação da diferença entre o corpo da medicina e o corpo da histeria. O sintoma histérico não é o negativo do orgânico, isto é, constatar a ausência de correlativo orgânico não significa encontrar necessariamente o sintoma histérico (Quinet, 2005; Bursztyn, 2008). Assim, dando início às formulações sobre a especificidade do corpo histérico, Freud (1893/1996a) afirma:

[...] a lesão nas paralisias histéricas deve ser completamente independente da anatomia do sistema nervoso, pois, nas suas paralisias e em outras manifestações, a histeria se comporta como se a anatomia não existisse, ou como se não tivesse conhecimento desta. (p. 216)

Vislumbra-se, neste trecho, a falta de conhecimento da histérica sobre a anatomia orgânica, que age como se esta não existisse. Freud (1893/1996a) descobre, então, que a histérica toma os órgãos pelo sentido corrente, popular, dos nomes que eles têm. Segundo o autor, "a perna é a perna até sua inserção no quadril, o braço é o membro superior tal como aparece visível sob a roupa" (p. 216). Nesse sentido, constata-se que o corpo histérico é um corpo marcado pela linguagem popular. Como afirmam Lazzarini e Viana (2006), no sintoma histérico encontra-se uma representação corporal constituída pelo imaginário social.

Com isso, a noção de corpo representado se instaura, corpo este que encarna o simbólico e subverte a concepção do corpo natural biológico (Naves, 2007). Em Estudos sobre a histeria, Breuer e Freud (1893-1895/1996) destacam a incidência da linguagem no sintoma histérico e sua determinação simbólica. Constatando, assim, que o sintoma na histeria é tecido de linguagem (Quinet, 2005; Bursztyn, 2008; Pollo, 2016).

A incidência da simbolização nos sintomas corporais é particularmente evidente no caso clínico de Elisabeth von R., no qual Freud, por exemplo, sinaliza haver uma conexão entre o sintoma de paralisia da perna da paciente com a expressão "ficar sozinha". O autor afirma se tratar de uma "paralisia baseada na 
simbolização" (p. 182), constatando, assim, que os sintomas somáticos podem ser constituídos por uma simbolização.

A respeito da paralisia da perna de Elisabeth von R., Quinet (2005) pontua que o termo em alemão Alleinstehen significa tanto "ficar só" como "ficar de pé". Assim, segundo Quinet, a solidão de que a paciente se queixava estava inscrita em suas pernas por meio do sintoma. A paciente não conseguia ficar só e, por conta disso, não conseguia ficar de pé, nem caminhar. Nesse sentido, Freud constata que o sintoma de paralisia da perna vem no lugar do desamparo de Elisabeth que não conseguia avançar em sua vida.

No que tange à relação entre o sintoma histérico e a linguagem, Freud afirma que "a histeria tem razão em restaurar o significado original das palavras" (Breuer \& Freud, 1893-1895/1996, p. 209). Percebemos, então, que na histeria há uma recuperação do significado originário das palavras, que se atualiza no sintoma. Outro exemplo deste fenômeno destacado por Freud é o fato de que, na histeria, o sujeito toma as expressões ao pé da letra. Assim, no caso de Elisabeth von R., as expressões "não ser capaz de dar um único passo à frente" e "não ter nada em que se apoiar" (p. 204) serviram de ponte para um ato de conversão da paciente.

Durante o tratamento de Elisabeth von R., Freud constata que as dores da paciente em determinado momento começaram a "participar da conversa" ( $p$. 178). Segundo o relato do autor, quando a sessão se iniciava, a paciente estava sem dor e, ao despertar uma lembrança, surgia uma sensação de dor por vezes tão aguda que Elisabeth estremecia e punha a mão no local doloroso. Enquanto a paciente se recordava, a dor persistia, alcançava seu clímax no ato de contar a parte essencial da lembrança e desaparecia com a última palavra de sua fala.

Freud afirma também que o sintoma histérico de dor encontrava vias de se desfazer por meio da fala, o que foi sintetizado por ele ao afirmar que era preciso que a paciente falasse "até que a dor se esgotasse pela fala" (p. 178). Desse modo, Freud afirma que começou a usar as dores da paciente como bússola para orientálo em sua escuta. Segundo Quinet (2005), a interpretação analítica tem a função de fazer o sujeito falar a palavra que foi recalcada e não dita ou "mal-dita".

O caso clínico de Emmy von N. também é representativo desta questão. Nele, Freud afirma que os sintomas motores da paciente representam "símbolos destes [dos traumas] nas atividades da memória" (Breuer \& Freud, 1893- 
1895/1996, p. 128), afirmando assim seu aspecto de "símbolo mnêmico" da vivência traumática. No caso de Emmy, têm-se dois exemplos disto: o sintoma conversivo de estalido com a língua remete a uma representação antitética e a gagueira de Emmy a uma excitação psíquica convertida em atividade motora. Freud também afirma que esses sintomas, apesar de possuírem origens diferentes, possuem um núcleo em comum: uma ligação originária ou de longa data com os traumas.

Freud diferencia as produções de Emmy das alucinações verbais da psicose aguda, uma vez que se assemelham aos fenômenos oníricos. Nos estados psíquicos de Emmy, de alterações patológicas da consciência, Freud percebe uma limitação da consciência e uma compulsão a associar, semelhante ao que ocorre nos sonhos. André (1998) pontua que, na histeria, não se trata de significantes que surgem no real, como ocorre nas psicoses, trata-se de sonhos, isto é, significantes passeando pelo imaginário, ligados a um intenso sentimento de realidade. $\mathrm{O}$ autor observa que a estrutura da histeria se manifesta pela "inserção do significante no imaginário do corpo" (p. 97). Aqui, percebe-se o que Freud pontuou como a homogeneidade do sintoma histérico com o processo do sonho, a figuração em forma de rébus.

Sobre as dores sentidas pela paciente Emmy, Freud refere-se ao fato de que essas se dividem em dois grupos: um grupo de dores determinadas organicamente e outro que consiste em "lembranças de dores". Neste último, vislumbra-se a compreensão das dores como símbolos mnêmicos de um período de grande relevância na vida da paciente.

O caso Dora (1905[1901]/2016) também é emblemático no que concerne à importância das palavras para a formação dos sintomas histéricos. Freud aponta como a palavra "catarro", com a qual Dora designa a sua doença, tinha diversos desdobramentos de sentidos e se referia ao que ele denominava de entroncamento. Este último se refere a palavras que possuem um sentido ambíguo e revelam um “'entroncamento' na via de associações” (1905/2016, p. 247). Ou seja, estas palavras possibilitam uma via de acesso a pensamentos inconscientes.

Com isso, podemos observar o papel dos significantes ${ }^{1}$ nos sintomas histéricos. Posteriormente, Lacan (1953/1998c) vai trazer desdobramentos e

\footnotetext{
${ }^{1} \mathrm{O}$ conceito de significante consiste em um termo central na obra de Lacan, tendo este produzido um efeito fundamental em sua releitura da obra freudiana. A partir de Lacan, o
} 
contribuições a esse aspecto de determinação simbólica do sintoma, afirmando que este "é o significante de um significado recalcado da consciência do sujeito [...] símbolo escrito na areia da carne" (p. 282). Aqui, observamos a inscrição do significante no corpo testemunhado pelo sintoma.

Nesse sentido, Naves (2007) assinala que o corpo para a psicanálise tratase de um corpo representado que encarna o simbólico. Este corpo é habitado por uma estrutura significante que o designa à determinação de significação.

Lacan (1953/1998c) afirma que o sintoma é uma fala em plena atividade, uma vez que "inclui o discurso do outro no segredo de seu código" (p. 282). Além disso, pontua que Freud encontrou a linguagem primeira dos símbolos decifrando essa fala, que se apresenta, por exemplo, nos hieróglifos da histeria.

Em seus comentários sobre as contribuições lacanianas, Prado (2000) afirma que o corpo da histeria possui as palavras como marca dos pontos de fixação corporal e, também, são estas que imprimem os contornos originais e iniciais do corpo.

Torna-se importante ressaltar que Freud, ao circunscrever a determinação simbólica dos sintomas histéricos, depara-se com uma radicalidade, ou seja, que a linguagem constitui o sujeito. Ao encontrar as marcas de expressões populares no corpo da histérica, Freud constata esse significado originário já impresso nela. Esta apreensão definitiva e primordial será enfatizada e circunscrita por Lacan. É porque a linguagem constitui o sujeito que se manifesta o sofrimento. E o que revela a histérica é que a linguagem pode reconfigurar a carne do corpo. A histeria se apresenta como avesso do discurso médico pois evidencia essa radicalidade, ela faz algo que não tem nome, algo de singular.

\section{3 \\ Conversão somática e disponibilidade do corpo na histeria}

Como dito anteriormente, Freud (1894/1996i) afirma que o fator característico da histeria deve ser destacado como a capacidade de conversão, que pode ser expressa na aptidão psicofísica para transpor enormes somas de excitação

simbólico é repensado sob a forma do significante. Apesar da relevância deste conceito, este não será aprofundado no presente trabalho. 
para a inervação somática. Essa aptidão só conduz à histeria ao ocorrer incompatibilidade psíquica ou acúmulo de excitação.

Com relação à distribuição da excitação, Freud (1893/1996a) afirma que, na histeria, a excitação forçada a escoar-se por um canal impróprio (pela inervação somática), eventualmente reencontra o caminho de volta para a representação da qual se destacou, compelindo o sujeito a elaborar a representação associativamente ou a livrar-se dela em ataques histéricos - como ocorre, respectivamente, em sintomas crônicos e em ataques histéricos.

A conversão, portanto, se refere a um deslocamento e a um salto para uma ordem distinta de funcionamento. O deslocamento opera, desde a ordem do representacional para a inervação corporal, e se expressa em anestesias, paralisias, espasmos, dentre outros (Alonso \& Fuks, 2012).

Destaca-se a diferença entre falar de disponibilidade do corpo e do fenômeno conversivo, caracterizado por Freud como algo misterioso, que consiste na passagem da intensidade do afeto, a energia psíquica, para a inervação somática. Ao mesmo tempo em que Freud postula uma concepção econômica da conversão como transformação, transposição de energia psíquica libidinal para energia somática, aponta também, como vimos anteriormente, a concepção simbólica da conversão, referindo-se ao sintoma como expressão simbólica de ideias reprimidas, que funcionam de forma a encobri-las (Alonso \& Fuks, 2012).

David-Ménard (2000) questiona o uso feito por Freud do termo “conversão" para caracterizar a especificidade da histeria e, também, as noções, implicadas nesse conceito, de "passagem", "transporte" e "transposição" de um afeto do domínio psíquico para o somático. Para a autora, estas noções enfatizam a separação entre psíquico e somático. Ela lembra que, posteriormente, Freud utiliza a noção de "pantomima" para caracterizar os sintomas e crises histéricas, definindo-os como uma pantomima do gozo sexual, e afirma ser este termo mais apropriado.

Além dos sintomas, é notável na histeria uma relação particular com o corpo que diz respeito a uma disponibilidade deste. Freud denominou esta característica de complacência somática. Elia (1995) observa que, enquanto o corpo é o campo de expressão do sintoma histérico, a complacência somática se refere ao que viabiliza essa via de expressão. Com esse conceito, Freud delimita que o corpo se submete, se faz complacente a uma ordem de fenômenos que se 
impõe, nele esculpindo as formas do desejo e suas vicissitudes. Eis o significado deste termo: "oposto (somático) da recusa a receber" (p. 106). Desse modo, segundo Elia, esta noção exprime a ideia de que o corpo deixa de se opor a receber e expressar um representante (como tal, simbólico) da pulsão.

Segundo Winograd e Mendes (2009), a complacência somática demonstra que cada corpo, em sua constituição biológica e orgânica, apresenta pontos de vulnerabilidade, por meio dos quais os processos psíquicos podem se manifestar. Parte do corpo ou um órgão específico facilitam a expressão simbólica do conflito psíquico.

O corpo, assim, se submete e recebe uma inscrição estranha a ele, "uma mensagem ignorada pelo autor, a ser entendida em seu valor metafórico e inscrita em hieróglifos sobre um corpo doente porque parasitado" (Chemama, 1995, p. 96). A ênfase aqui se dá no corpo simbólico, um corpo mapeado por marcas e traços significantes, irredutíveis à ordem biológica. Segundo Elia (1995), “escultura do inconsciente, o corpo histérico é a encarnação da sexualidade freudiana, a sexualidade tal como concebida pela psicanálise" (p. 108).

Destacamos que, a partir do momento que se trata de um corpo marcado pela linguagem, está-se falando também de um corpo marcado pelo desejo e por investimentos libidinais. Nos primeiros escritos de Freud, percebe-se uma preocupação em pensar o corpo capturado pela linguagem e marcado pelo desejo, sendo um instrumento que permite a expressão de representações recalcadas. Nesse período, o corpo da histérica se apresenta como um sintoma, ao expressar um conflito entre uma representação investida libidinalmente e a pressão do recalque (Naves, 2007).

\section{4 \\ O sexual traumático}

$\mathrm{Na}$ "Comunicação preliminar" e nos relatos de casos clínicos de Estudos sobre a histeria (Breuer \& Freud, 1893-1895/1996), o trauma aparece como algo excessivo, caracterizado como um "corpo estranho", atuando insistentemente no psiquismo, ao passo que, em "A psicoterapia da histeria", Freud postula que o caráter traumático de uma experiência é a sua natureza sexual. 
Com isso, nos relatos clínicos de Estudos sobre a histeria, podemos observar algumas passagens nas quais Freud e Breuer aludem à ausência de fator sexual nos comportamentos das pacientes histéricas. Por exemplo, no caso clínico de Anna O., Breuer afirma "a noção de sexualidade era surpreendentemente não desenvolvida nela" (p. 57); outro exemplo é o caso de Emmy von N., em que Freud escreve que "dentre todas as informações íntimas que me foram dadas pela paciente, houve uma ausência completa do elemento sexual" (p. 134).

Paralelamente, notam-se algumas passagens nas quais o papel da sexualidade começa a ser delineado. No caso de Emmy, apesar de notar a ausência do elemento sexual, Freud afirma ser este o elemento "passível mais do que qualquer outro de ocasionar traumas" (p. 134); no caso de Katharina, Freud reflete sobre a presença da sexualidade em uma fase anterior à adulta, nas palavras do autor: "gostaria, neste ponto, de externar a dúvida [...] se mesmo os adolescentes não possuem conhecimento sexual com muito mais frequência do que se supõe ou do que eles mesmos acreditam" (p. 164-165).

A percepção da importância da sexualidade vinha crescendo gradualmente. Em um artigo intitulado As neuropsicoses de defesa, Freud (1894/1996i) afirma que, nas neuroses, tanto na histeria quanto na neurose obsessiva, a representação patogênica era, sobretudo, aquela de conteúdo sexual.

Em "A psicoterapia da histeria", último capítulo de Estudos sobre a histeria, datado de 1895, vislumbra-se o reconhecimento de Freud da importância do sexual e, com isso, seu rompimento com Breuer, por este não admitir o fator sexual na etiologia das neuroses. Freud formula a noção de sexualidade como traumática e afirma que a etiologia da neurose deve ser buscada em fatores sexuais, instituindo a natureza sexual da experiência como o caráter traumático desta.

Pollo (2016) destaca que esse artigo constitui um marco em relação à sexualidade. Observa-se que, anteriormente, Freud já tratava da natureza sexual da experiência traumática, contudo, esta aparecia como um impasse ou vacilação entre a ideia da ausência de reação levar ao trauma ou a seu contrário. Em 1895, segundo a autora, há uma virada, na qual Freud aponta uma equivalência entre traumático e sexual, que implica em uma não inscrição na linguagem. Trataremos dessa questão mais adiante. 
Em "A psicoterapia da histeria”, Freud descreve o psiquismo como uma estrutura complexa de três dimensões: 1) núcleo de lembranças, no qual a ideia patogênica encontra sua manifestação mais pura; 2) um arquivo de lembranças, material mnêmico, que se forma em torno do núcleo, como coleções dispostas em sequências lineares, um arquivo de documentos ou maço de papéis; 3) o agenciamento destas lembranças como um fio lógico.

Os dois primeiros pontos possuem caráter morfológico, tratando-se do arquivo de lembranças da histérica. A terceira espécie de arranjo possui caráter dinâmico e é caracterizado por Freud como o fio lógico que se dirige ao núcleo. Este fio consiste em um caminho irregular e sinuoso, de caráter diverso e singular em cada caso. Freud o compara aos lances em ziguezague do cavalo em um jogo de xadrez, ilustrando, assim, esta linha interrompida que alcança o núcleo patogênico, passando pelos caminhos mais indiretos (Breuer \& Freud, 18931895/1996).

Para descrever as características deste fio lógico, Freud utiliza o termo "sobredeterminação" e aponta a existência de um sistema convergente com pontos nodais, em que dois ou mais fios se juntam e permanecem como um só. O autor relaciona esse mecanismo à formação dos sintomas, que são determinados de vários modos (Breuer \& Freud, 1893-1895/1996).

Nesse sentido, Freud formula a existência de uma sequência ininterrupta que se alastra desde os resíduos mnêmicos não alterados das experiências e atos de pensamentos afetivos até os sintomas histéricos que se apresentam como "símbolos mnêmicos" destas experiências e pensamentos. O autor formula que "quase se pode dizer que o símbolo histérico substituiu completamente a coisa" (Breuer \& Freud, 1893-1895/1996 citado por Pollo, 2016). Desse modo, Pollo (2016), a partir de uma leitura lacaniana, observa que Freud define a relação causal da histeria como "uma relação simbólica", como um encadeamento de símbolos (significantes) ou ideias limítrofes - ideias patogênicas - que se apossam do corpo. Há, portanto, um núcleo traumático que se alastra até os sintomas histéricos que, como "símbolos mnêmicos", funcionam como substitutos.

A compreensão de um núcleo traumático de "resíduos mnêmicos não modificados das experiências e atos de pensamento afetivos" (Breuer \& Freud, $1893-1895 / 1996$, p. 320) aponta para a centralidade do trauma no psiquismo, em 
torno do qual se formam os arquivos de lembranças, e que possui uma sequência ininterrupta até os sintomas histéricos. Destaca-se também a relação estabelecida por Freud entre trauma e vivências não alteradas e também o caráter afetivo dos atos de pensamentos presentes neste núcleo.

André (1998) salienta que a novidade trazida por Freud nesse texto é apontar para um núcleo traumático, o chamado "umbigo", para o qual converge uma série de recordações desenvolvidas por associações lógicas, reunindo-se por temas. O autor sugere que este núcleo central, este umbigo em torno do qual tudo se constrói, relaciona-se a algo inominável. Aqui, relacionamos essa descrição com a hipótese psíquica apresentada por Freud sobre o caso Emmy von N., em que o autor aponta para um núcleo comum aos sintomas conversivos da paciente, isto é, uma ligação originária com o trauma.

\section{5 Desenvolvimentos da teoria do trauma: o papel da sexualidade}

Em 1896, no texto A hereditariedade e a etiologia das neuroses, Freud formula a "teoria da sedução" para dar conta da questão sexual. O autor afirma que, a partir do método psicanalítico e da investigação da origem dos sintomas histéricos, foi possível atingir o ponto de partida do processo patológico, sendo este a ação de um agente: uma lembrança relacionada à vida sexual. Esta lembrança possui duas características essenciais: (1) de ser uma experiência de caráter precoce e de cunho sexual provocada por um abuso cometido por outra pessoa; (2) ter ocorrido no período da infância. Nas palavras do autor:

\footnotetext{
esse agente é, de fato, uma lembrança relacionada à vida sexual, mas que apresenta duas características de máxima importância. O evento do qual o sujeito reteve uma lembrança inconsciente é uma experiência precoce de relações sexuais com excitação real dos órgãos genitais, resultante de abuso sexual cometido por outra pessoa; e o período da vida em que ocorre esse evento fatal é a infância - até a idade de 8 ou 10 anos, antes que a criança tenha atingido a maturidade sexual. (Freud, 1896/1996j, p. 151)
}

Assim, a criança sofre a ação sexual de um adulto ou de outra criança mais velha, contudo, por estar na primeira infância, a excitação sexual surte pouco ou nenhum efeito na época, mas sendo uma experiência de potencial traumático, cujo traço psíquico é preservado. Posteriormente, na puberdade, sucede a ressignificação da experiência como tendo sido da ordem do sexual, e seu traço 
psíquico inconsciente é despertado. Segundo Freud, ocorre a "ação póstuma de um trauma sexual" (p. 152).

Garcia-Roza (1985) sublinha que a teoria do trauma formulada em Estudos sobre a histeria possuía um problema implícito, uma vez que Freud ainda não havia admitido a sexualidade infantil. Assim, a noção de um trauma sexual na infância trazia complicações, devido à ausência do componente sexual nesse período. Em função disso, a teoria do trauma em dois momentos traz um desdobramento e uma resolução para essa questão, uma vez que é o segundo momento que confere o caráter traumático ao primeiro. Nesse sentido, a primeira cena ocorre na infância e se refere a uma vivência de sedução sexual, cujo caráter sexual não é percebido pela criança, e cuja excitação sexual não se produz nela. A segunda cena, por sua vez, ocorre na puberdade, a partir do advento da sexualidade, e consiste em uma vivência não necessariamente de caráter sexual, que evoca a primeira por meio de um traço associativo, transformando a lembrança da primeira cena em uma lembrança patogênica.

Além disso, Freud (1896/1996j) afirma que a natureza da influência sexual interfere na espécie patológica de neurose. Há, portanto, uma diferença capital entre a experiência sexual ocorrida na histeria e na neurose obsessiva. $\mathrm{Na}$ base da etiologia da histeria, encontra-se uma experiência sexual passiva e, na neurose obsessiva, observa-se a ocorrência de um evento que proporcionou prazer, isto é, a existência de um elemento ativo em contraste com o elemento passivo na vida sexual da histérica.

Em 1896, na Carta 52 a Fliess, Freud (1950[1896]/1996c) define uma hipótese sobre o trauma decorrente do que percebia na clínica. Os relatos das histéricas alegavam que elas teriam sofrido uma sedução, mais provavelmente sendo vítimas de uma sedução do próprio pai. Assim, Freud constrói a ideia de que haveria uma primeira geração perversa e uma segunda geração histérica, sendo a histeria o resultado de uma sedução feita pelo pai e de um repúdio à perversão. Segundo o autor:

Cada vez mais me parece que o ponto essencial da histeria é que ela resulta de perversão por parte do sedutor, e mais e mais me parece que a hereditariedade é a sedução pelo pai. Assim surge uma alternância de gerações: $1^{\mathrm{a}}$ geração: Perversão; $2^{\mathrm{a}}$ geração: Histeria e consequente esterilidade. Por vezes, há uma metamorfose dentro de um mesmo individuo: pervertido durante a idade do vigor e, depois, passado um período de angustia, histérico. Por conseguinte, histeria não 
é sexualidade repudiada, mas, antes perversão repudiada (Freud, 1950[1896]/1996c, p. 292).

Nesse sentido, a teoria do trauma enquanto sedução vai se transformando e dando lugar à noção de fantasia e de realidade psíquica. Em 1897, na Carta 59, pode-se ver uma primeira menção à noção de fantasias histéricas, que servirá de base para o abandono da teoria da sedução. $\mathrm{O}$ autor escreve:

O aspecto que me escapou na solução da histeria está na descoberta de uma nova fonte a partir da qual surge um novo elemento da produção inconsciente. $\mathrm{O}$ que tenho em mente são as fantasias histéricas, que, habitualmente, segundo me parece, remontam a coisas ouvidas pelas crianças em tenra idade e compreendidas somente mais tarde. (Freud, 1950[1897]/1996d, p. 299)

Na Carta 69, encontramos o momento efetivo do abandono da primeira teoria do trauma, que tem como marco a notável afirmação de Freud (1950[1897]/1996f): "Não acredito mais em minha neurotica" (p. 315). Nesta correspondência, o autor enumera diferentes motivos para um novo postulado teórico. Em primeiro lugar, coloca um sentimento de descrença na teoria da sedução, seguido do abandono do tratamento de alguns pacientes; em segundo lugar, a necessidade de ter que apontar o pai em todos os casos como pervertidos, inclusive o seu próprio pai. E, em terceiro lugar, a descoberta de que não há indicações de realidade no inconsciente.

Segundo André (1998), a fala das histéricas a respeito da perversão paterna diz respeito, de alguma forma, ao saber pelo qual elas articulam que a sexualidade seja tão traumática para elas. A relação da histérica com o seu pai não deve ser reduzida à perversão deste último. Por exemplo, os casos clínicos de Miss Lucy e Elisabeth von R. apontam que a histérica não se encontra em uma posição apenas passiva diante do pai, ela "participa da edificação de uma relação de cumplicidade ambígua com ele” (p. 68), que se expressa no amor de Miss Lucy pelo seu patrão e nos cuidados de Elisabeth com o pai enfermo. O autor aponta que, na Carta 69, Freud percebe que, assim como a histérica, ele havia sido objeto de manobras de sedução pelo Outro, o que o leva a reformular a relação com o pai para colocá-lo como função central para o sujeito.

Assim, em 1897, Freud percebe a impossibilidade de distinguir, no relato das pacientes, o que era verdade e o que era ficção catexizada com afeto. Em seguida, o autor escreve que permanece aberta a possibilidade da fantasia sexual ter os pais como tema. Freud dá um salto teórico e desenvolve as noções de 
realidade psíquica e de fantasia, que permitem abandonar a tentativa de corresponder o relato da paciente com a realidade material. Aqui, temos um elemento para pensar na noção de desejo para a psicanálise.

Em 1900, na Interpretação dos sonhos, Freud (1900/19961) formula mais assertivamente a noção de realidade psíquica. Colocando que "o inconsciente é a verdadeira realidade psíquica; em sua natureza mais íntima, ele nos é tão desconhecido quanto a realidade do mundo externo", e, além disso, "é tão incompletamente apresentado pelos dados da consciência quanto o é o mundo externo pelas comunicações de nossos órgãos sensoriais" (p. 634, grifos do autor). Freud postula, assim, que a realidade psíquica consiste em uma "forma especial de existência" (p. 641), que não deve ser confundida com a realidade material. Sendo assim, a realidade psíquica se refere ao desejo inconsciente que se acompanha da fantasia.

Em 1914, no texto História do movimento psicanalítico, Freud descreve a descoberta da realidade psíquica que deve ser pensada ao lado da realidade material. Segundo o autor, de início, havia uma necessidade de remontar as experiências descritas na clínica a algo no passado e, apenas posteriormente, foi possível perceber que os pacientes criavam essas cenas na fantasia. Aqui, pode-se pensar na ideia de que os sintomas e traumas são fictícios e, portanto, podem ser superados. Assim, é postulada a noção de construção ligada à origem do trauma, assim como a ideia de cena, de dramaturgia na cena da fantasia.

Deste modo, ele afirma que essa descoberta foi seguida da noção de que as fantasias destinavam-se a encobrir a atividade autoerótica dos primeiros anos de infância e, assim, foi possível formular a hipótese da sexualidade infantil. Nas palavras do autor:

[...] essas fantasias destinavam-se a encobrir a atividade autoerótica dos primeiros anos de infância, embelezá-la e elevá-la a um plano mais alto. E agora, de detrás das fantasias, toda a gama da vida sexual da criança vinha à luz. (Freud, 1914/1996p, p. 28)

Em História do movimento psicanalítico, Freud (1914/1996p) expressa que, no primeiro momento de investigação experimental pela análise, a hipótese da sexualidade infantil não era pensada. Inicialmente, percebia-se apenas a importância de remontar as experiências atuais ao passado. Aos poucos, as experiências do passado revelaram-se cada vez mais precoces, passando primeiro 
pela puberdade, período ao qual se atribuía o despertar dos impulsos sexuais, até que as pistas conduziram-no à infância e aos primeiros anos.

A noção de fantasia está intrinsecamente relacionada ao conceito de complexo de Édipo, cuja primeira menção se encontra na Carta 71, datada de 15 de outubro de 1897. A referência ao mito grego de Édipo surge a partir da autoanálise de Freud e da percepção de sua paixão por sua mãe e de um ciúme de seu pai. $\mathrm{O}$ autor escreve:

Verifiquei, também no meu caso, a paixão pela mãe e o ciúme do pai, e agora considero isso como um evento universal do início da infância [...] Sendo assim, podemos entender a força avassaladora de Oedipus Rex, apesar de todas as objeções levantadas pela razão contra a sua presença do destino; e podemos entender por que os "dramas do destino" posteriores estavam fadados a fracassar lamentavelmente. (Freud, 1950[1897]/1996g, p. 322)

Aqui, apesar da menção ao mito grego Oedipus Rex, o conceito de complexo de Édipo propriamente dito só será desenvolvido em 1924. Este permitirá o abandono da teoria da sedução para uma compreensão da importância da fantasia nos processos psíquicos e na reconstrução do trauma e do desejo presente na experiência traumática. Além disso, permite a passagem da realidade material para a realidade psíquica.

Apesar das menções a respeito do papel da fantasia, é possível dizer que a questão sexual permanece sem resposta por um bom tempo a partir da Carta 69. Esta resposta só virá com a construção teórica sobre a sexualidade infantil, elaborada apenas em 1905 (Naves, 2007).

Segundo Garcia-Roza (1985), a teoria da sedução não foi precisamente abandonada na obra freudiana. O que é deixado para trás, e ainda assim não inteiramente, é a busca de alcançar uma cena originária. Segundo observou Laplanche (1973 citado por Garcia-Roza, 1985), há uma sedução da qual nenhum sujeito pode se ver livre, qual seja, a sedução dos cuidados maternos.

Segundo Naves (2007), a teoria da sedução foi parcialmente abandonada por Freud, uma vez que há um abandono da hipótese de uma sedução praticada pelo pai, em favor de uma sedução desempenhada pela mãe. O que ocorre é uma passagem de uma concepção do pai como manifestamente perverso para uma mãe inconscientemente perversa, que estimula sexualmente o corpo da criança nos cuidados com seu corpo. Esta concepção só será apresentada em 1905 com o artigo Três ensaios sobre a teoria da sexualidade. 
Assim, em 1905, Freud institui que, tanto para o menino quanto para a menina, a sedução primária é exercida pela mãe. Trata-se de uma experiência primária de passividade sexual, na qual o bebê recebe carícias, desejos e emoções de quem dele se ocupa. Assim, segundo André (1998), “a descoberta do gozo sexual pela criança sempre ocorreu ao nível mais primário numa experiência passiva - no sentido em que é sempre do Outro que o sujeito recebe a sexualidade", com isso, afirma também que "o gozo sexual é sempre antecipado, na medida em que ele se apossa da criança na sua relação primeira com o Outro: a criança é inicialmente gozada, mais do que goza” (p. 88).

\section{6}

\section{Fantasias histéricas e bissexualidade}

Em 1905, no artigo Três ensaios sobre a teoria da sexualidade, Freud afirma que as psiconeuroses se fundamentam em forças pulsionais sexuais, de modo que os sintomas representam verdadeiros substitutos para os impulsos sexuais. Freud chega a afirmar que "os sintomas são a atividade sexual dos doentes" (p. 60), isto é, a vida sexual na neurose se manifesta unicamente, ou principalmente, nos sintomas. No caso da histeria, tais impulsos buscam descarga e a encontram mediante o processo de conversão - em fenômenos somáticos.

Além disso, o autor constata a existência de um par de opostos na histeria, definindo-o como um "contraditório enigma da histeria" (p. 62): o antagonismo entre uma enorme necessidade sexual e uma exacerbada rejeição da sexualidade. Assim, a enfermidade é produzida a partir da pressão do instinto e o seu oposto, a rejeição da sexualidade, não resolvendo, assim, o conflito, mas escapando deste, transformando os impulsos libidinais em sintomas.

Em 1908, no artigo Fantasias histéricas e sua relação com a bissexualidade, Freud apresenta como os sintomas histéricos dizem respeito a fantasias, espécie de "devaneios" ou sonhos diurnos, que se referem a satisfações de desejos e originam-se de privações ou anseios. Desse modo, Freud constata que um ataque histérico consiste em uma fantasia inconsciente que irrompe involuntariamente. Além do ataque histérico, o autor observa que as fantasias inconscientes são os precursores psíquicos imediatos de uma série de sintomas 
histéricos, que devem a elas sua procedência. Esta relação entre os sintomas e as fantasias revelam características da sexualidade dos psiconeuróticos.

Assim, Freud (1908/1996n) enfatiza o caráter complexo do nexo entre as fantasias inconscientes e o sintoma, tendo estas dificuldades para adquirir expressão de forma análoga à relação entre os pensamentos oníricos latentes e os elementos do conteúdo onírico "manifesto". Com isso, Freud elenca nove fórmulas para descrever o sintoma histérico, sendo este: (1) símbolo mnêmico de vivências (traumáticas); (2) substituto, produzido por conversão, de vivências traumáticas; (3) expressão do cumprimento de um desejo; (4) realização de uma fantasia inconsciente que serve ao desejo; (5) serve à satisfação sexual e representa uma parte da vida sexual da pessoa; (6) retorno à sexualidade infantil; (7) compromisso entre pulsões opostas: uma de componente sexual e outra que se empenha em suprimi-la; (8) uma representação de caráter sexual; (9) expressão simultânea de fantasias sexuais inconscientes masculinas e femininas.

Freud enfatiza a definição número sete, definindo esta como a que exprime de maneira mais completa a natureza do sintoma histérico como realização de uma fantasia inconsciente e, em conjunto com a oitava, contempla a importância do fator sexual.

Além disso, a definição número dez consiste em uma novidade trazida nesse texto, sendo esta a significação bissexual dos sintomas histéricos, ou seja, a noção de que um sintoma histérico expressa, ao mesmo tempo, duas fantasias sexuais, uma de caráter masculino e outra de caráter feminino. Freud traz o exemplo de um ataque histérico no qual a paciente faz, concomitantemente, os papéis masculino e feminino da fantasia sexual subjacente: com uma mão, ela segurava o vestido em seu corpo (como uma mulher) e, com a outra mão, buscava afastá-lo (como um homem).

Pollo (2016) afirma que é possível conceber a série de fórmulas enunciada por Freud como uma progressão da construção dos sintomas histéricos, e também da elaboração feita ao longo dos anos sobre a natureza desses sintomas. Assim, a autora faz uma reconstrução progressiva dos sintomas histéricos, ilustrando o processo desde "um início", relacionando-o à formação do sujeito histérico, sua relação com o Outro e com o corpo. Nesse sentido, a autora afirma que se pode dizer que a histeria tem início no momento que um significante (símbolo) vem no lugar da Coisa (das Ding), isto é, da mãe como Outro primordial do sujeito ou 
como "outro pré-histórico", nas palavras de Freud. Em seguida, têm-se o aspecto conversivo desse significante, em que este se inscreve no corpo e não em uma cadeia de pensamentos. Aqui, já se trata de um sujeito desejante. Seguidamente, apresenta-se a fantasia inconsciente, permitindo a manutenção ou a continuidade do desejo e a formação de novos sintomas como um compromisso entre pulsões. Nesse sentido, a fantasia atribuída à significação fálica (segundo Lacan, toda significação é fálica e está no interior da significação sexual) diz respeito ao regresso, à reaquisição e à fixação da sexualidade infantil e, além disso, é constituída por uma parcela da vida sexual vigente das histéricas.

Em 1909, no artigo Algumas observações gerais sobre ataques histéricos, Freud trata novamente sobre a relação entre os ataques histéricos e as fantasias inconscientes, trazendo novos elementos para este nexo. Segundo o autor, os ataques histéricos consistem em "fantasias traduzidas para a esfera motora, projetadas na motilidade, representadas por meio de mímica” (p. 209).

A relação entre o ataque histérico e o sonho também ganha novos contornos, uma vez que Freud afirma que, com frequência, um sonho substitui um ataque e mais regularmente explica-o, sendo possível que a mesma fantasia inconsciente encontre expressão diversa no sonho e no ataque. Além disso, raramente é possível chegar ao conhecimento da fantasia representada em um ataque apenas observando-o, uma vez que a representação pantomímica da fantasia experimente, devido à censura, deformações semelhantes às deformações do sonho, tornando-as pouco inteligíveis. Assim, o ataque histérico necessita da mesma elaboração interpretativa que realizamos com os sonhos noturnos.

Assim, em 1909, Freud reúne cinco fatores importantes para compreender o mecanismo de construção do ataque histérico a partir da relação com a fantasia inconsciente, que define como semelhante à técnica conhecida pela interpretação dos sonhos, são estes: (1) o mecanismo de condensação, que reúne elementos de duas (ou mais) fantasias no mesmo material, assim, as mesmas inervações servem aos dois ou mais propósitos; (2) a identificação múltipla, que torna possível a representação das atividades de duas pessoas na fantasia, como no caso citado em 1808, da paciente que, com uma mão, arranca o vestido e, com a outra, o segura preso ao corpo; (3) inversão antagonística das inervações, que é semelhante à transformação de um elemento em seu oposto, característica do trabalho do sonho, caso de um abraço representado no ataque histérico como seu oposto, puxando-se 
convulsivamente os braços para trás, como no notório "arc de cercle";

inversão da sequência temporal, quando as fantasias inconscientes subjacentes ao ataque são construídas em uma sequência temporal inversa e o ataque histérico representa, por exemplo, um coito que se inicia pelo orgasmo.

Além disso, Freud (1909[1908]/1996o) descreve as leis de funcionamento do ataque histérico. $\mathrm{O}$ ataque pode ser despertado, em primeiro lugar, associativamente, quando o conteúdo do complexo é evocado por algo da vida consciente; em segundo lugar, organicamente, a partir da relação entre o pensamento e o corpo, elevando um investimento libidinal; em terceiro lugar, pela "fuga para a doença", quando a realidade se torna demasiadamente penosa; e, em quarto lugar, como um ganho secundário, quando o ataque é calculado para certas pessoas no entorno. Sobre o quarto ponto, Pollo (2016) aponta que esse endereçamento do ataque histérico a um outro não deve ser entendido como qualquer outro, mas sim apenas a um "substituto encarnado do 'outro préhistórico"” (p. 38).

Por fim, Freud (1909[1908]/1996o) aponta novamente a relação entre o ataque histérico e a sexualidade infantil, afirmando que o ataque consiste em uma substituição da satisfação autoerótica praticada no passado e, desde então, abandonada. Assim, constrói os estágios de um ataque histérico: (1) satisfação autoerótica sem conteúdo ideativo; (2) a vinculação desta satisfação a uma fantasia; (3) renúncia ao ato, mantendo a fantasia; (4) recalque dessa fantasia, desenvolvendo-se apenas o ataque histérico; (5) retorno do recalcado, que insiste em se expressar, representando a recuperação da satisfação perdida.

\section{7}

O sonho de injeção de Irma: o encontro com algo de inominável

\footnotetext{
"Quero pôr em palavras mas sem descrição a existência da gruta que faz algum tempo pintei - e não sei como. Só repetindo o seu doce horror, caverna de terror e das maravilhas, lugar de almas aflitas, inverno e inferno, substrato imprevisivel do mal que está dentro de uma terra que não é fértil. Chamo a gruta pelo seu nome e ela passa a viver combateu miasma. Tenho medo então de mim que sei pintar o horror, eu, bicho de cavernas ecoantes que sou, e sufoco porque sou palavra e também o seu eco." (Clarice Lispector, 1973/1998)
}

Analisaremos, nesse momento, algo que se apresenta nos primeiros escritos de Freud e que impulsiona sua produção. Lacan (1964/2008a) afirma ser 
evidente que, na pesquisa de Freud, é do real que ele cuida, sendo a psicanálise “orientada para aquilo que, no coração da experiência, é o núcleo do real” (p. 58). Assim, afirma que, na origem da experiência analítica, o real se apresenta "na forma do que nele há de inassimilável" (p. 60, grifo do autor), isto é, na forma do trauma.

Assim, André (1998) aponta que há, nos primeiros textos de Freud, um “encontro, no coração do trauma, de um real, que aparece como 'o correlativo da representação"” (p. 67). Para o autor, o real que havia impulsionado a produção de Freud, esta verdade primeira da doutrina freudiana, vai sendo sucessivamente recoberto pelo simbólico e pelo desenvolvimento da teoria da castração. Ele observa que, em 1895, no Projeto para uma psicologia científica, Freud faz uma tentativa de demarcar esse real inominável, reintegrá-lo no sistema simbólico e inseri-lo em uma formalização. André (1998) lembra que Freud escreve em 1938, no Esboço de psicanálise, que “o real será sempre irreconhecível” (p. 66).

Naves (2007) constata a existência de algumas "lacunas teóricas" nos escritos de Freud no período entre a Carta 69, na qual Freud abandona a teoria da sedução, e a elaboração da sexualidade infantil em 1905, com a qual Freud busca responder à questão sexual. Para a autora, estas lacunas teóricas na teoria da histeria indicam o surgimento de uma não significação, que, contudo, não será delimitada no arcabouço teórico de Freud, que, em vez disso, se agarra na tentativa de comprovar a teoria da sexualidade. Para a autora, apenas em 1920, Freud irá retomar a questão da não significação com o conceito de pulsão de morte. Segundo constata a autora, a partir de 1920, o criador da psicanálise não faz indicações mais precisas sobre o hors-sense da dinâmica histérica.

Para Naves (2007), a luta do histérico não se dá em um conflito de caráter sexual, ao menos, não somente em um conflito desta ordem. Sendo assim, o histérico não se defende de uma sexualidade incipiente, pelo contrário, busca de forma errante um acesso mais pleno a ela. A autora concebe a sexualidade na histeria a partir da vertente da pulsão de morte, que se apresenta em uma luta do histérico contra a não representação. Assim, na conjugação entre Eros e Tanatos na constituição da histeria, haveria uma primazia da pulsão de morte. A autora ressalta, contudo, que as noções de conflito e de defesa de representações sexuais são a única via que permite à histeria um afastamento da psicose e a ascensão do desejo como representante de Eros. 
Nesse sentido, Teixeira (2010) aponta que a ideia do surgimento de algo que suspende o sentido encontra-se presente na perspectiva inaugurada por Freud a respeito do sexual. Para o autor, esta concepção é apresentada inicialmente a partir do sonho de Freud denominado "sonho da injeção de Irma" (1900/19961). Este sonho do psicanalista vienense é apontado por diversos autores como um momento de descontinuidade na teoria freudiana, em que há um reposicionamento subjetivo de Freud (André, 1998; Teixeira, 2010; Bassols, 2016).

A importância deste sonho é reconhecida pelo criador da psicanálise na Carta 137, de 12 de junho de 1900, como descrito em A interpretação dos sonhos (1900/19961), na qual afirma, não sem uma dose de humor, ter imaginado uma plaqueta à porta da casa de Bellevue com as seguintes palavras gravadas: "Nesta casa, em 24 de julho de 1895, o segredo dos sonhos foi revelado ao dr. Sigm. Freud" (p. 155). Assim, podemos perceber que o autor considera este sonho como inaugural, sendo através dele que o segredo dos sonhos foi revelado. Além disso, Lacan (1954-1955/2010) reforça a importância deste sonho, ao afirmar que este deve ser lido como se realiza a leitura de um texto sagrado.

Para compreender este sonho, torna-se importante conhecer o contex to no qual ele foi concebido. Irma era uma paciente histérica de Freud que, ao término de seu tratamento, não perdera totalmente seus sintomas e, segundo o autor, não aceitava as propostas deste para a solução de seu conflito. Por conta desses fatores, e pelo fato de Irma ser uma conhecida de sua família e integrante de seu ciclo social, Freud tinha grandes dificuldades com Irma. Somando-se a esses fatores, têm-se um encontro de Freud com um colega de profissão que, ao the trazer notícias de sua antiga paciente, transparece sentimentos de recriminação com relação a sua conduta no tratamento de Irma. Na noite deste encontro, Freud adormece para sonhar o sonho da injeção de Irma. Eis o relato do sonho na íntegra:

Um grande salão - numerosos convidados a quem estávamos recebendo. - Entre eles estava Irma. No mesmo instante, puxei-a de lado, como que para responder a sua carta e repreendê-la por não ter ainda aceitado minha "solução". Disse-lhe: "Se você ainda sente dores, é realmente apenas por culpa sua." Respondeu ela: "Ah! se o senhor pudesse imaginar as dores que sinto agora na garganta, no estômago e no abdômen . . . - isto está me sufocando." - Fiquei alarmado e olhei para ela. Parecia pálida e inchada. Pensei comigo mesmo que, afinal de contas, devia estar deixando de perceber algum distúrbio orgânico. Levei-a até a janela e examinei-lhe a garganta, e ela deu mostras de resistências, como fazem as mulheres com dentaduras postiças. Pensei comigo mesmo que realmente não 
havia necessidade de ela fazer aquilo. - Em seguida, ela abriu a boca como devia e, no lado direito, descobri uma grande placa branca; em outro lugar, vi extensas crostas cinza-esbranquiçadas sobre algumas notáveis estruturas recurvadas, que tinham evidentemente por modelo os ossos turbinados do nariz. - Chamei imediatamente o Dr. M., e ele repetiu o exame e o confirmou... O Dr. M. tinha uma aparência muito diferente da habitual; estava muito pálido, claudicava e tinha o queixo escanhoado... (Freud, 1900/19961, p. 141-142)

Importante destacar que, neste sonho, entram em jogo as relações transferenciais de Freud com os seus colegas médicos. Quem errou com Irma? Quem portou maior saber sobre o seu padecimento? Muitas indagações e aflições são levantadas e analisadas no ensaio que Freud escreve sobre o sonho, o que o conduz a revelar e dar ênfase ao tema do inominável a que a análise do sonho o conduz. O relato do sonho continua:

Meu amigo Otto estava também agora de pé ao lado dela, e meu amigo Leopold a auscultava através do corpete e dizia: "Ela tem uma área surda bem embaixo, à esquerda." Indicou também que parte da pele do ombro esquerdo estava infiltrada. (Notei isso, tal como ele fizera, apenas do vestido.) [...] M. disse: "Não havia dúvida de que é uma infecção mas não tem importância; sobrevirá uma disenteria, e a toxina será eliminada." [...] Tivemos também pronta consciência da origem da infecção. Não muito antes, quando ela não estava se sentindo bem, meu amigo Otto lhe aplicara uma injeção de um preparado de propil, propilos... ácido propiônico... trimetilamina (e eu via diante de mim a fórmula desse preparado, impressa em grossos caracteres)... Injeções como essas não deveriam ser aplicadas de forma tão impensada... E, provavelmente, a seringa não estava limpa. (Freud, 1900/19961, p. 141-142)

Assim, em 1900, Freud faz uma análise detalhada deste sonho e, a partir da premissa de que o sonho é sempre a realização de um desejo, interpreta o sentido do sonho como uma resposta ao seu desejo de se eximir da responsabilidade pelo resultado insatisfatório do tratamento de Irma.

Lacan (1954-1955/2010), por sua vez, reflete sobre o sentido do sonho proposto por Freud e questiona o fato de ele ter atribuído seu desejo onírico a uma motivação pré-consciente. Para o autor, deve-se partir do desejo inconsciente para compreender a chave do sentido do sonho. Com isso, ele distingue dois momentos nesse sonho. Primeiramente, as associações de Freud giram em torno de duas faces da resistência de Irma: ela resiste em aceitar a proposta de solução para seu tratamento e resiste em abrir a boca para um exame físico de sua garganta. Irma finalmente abre a boca e Lacan observa a descrição de Freud de um espetáculo medonho, a aparição de uma imagem aterradora do fundo da garganta de Irma. Nas palavras de Lacan: 
eis aí uma descoberta horrível, a carne que jamais se vê, o fundo das coisas, o avesso da face, do rosto, os secretados por excelência, a carne da qual tudo sai, até mesmo o íntimo do mistério, a carne, dado que é sofredora, informe, que sua própria forma é algo que provoca angústia (1954-1955/2010, p. 211)

Sobre esta imagem aterradora, Lacan (1954-1955/2010) nos leva a reconhecer a revelação de algo de inominável, revelação do real, naquilo que tem de menos penetrável, sem mediação, algo diante do que todas as palavras estacam. O autor identifica, nessa forma complexa e insituável, uma relação com o órgão feminino e a boca, o primeiro sendo o local de onde sai toda a vida e, o segundo, o local onde tudo é tragado. Além disso, afirma que a garganta de Irma remete à imagem da morte, onde tudo acaba.

O tema da morte já tinha sido abordado por Freud em sua análise do sonho, ao correlacionar as placas brancas da garganta de Irma à doença grave de sua filha, que correu risco de vida. Sobre essa parte do sonho, Freud afirma tratarse do umbigo do sonho, ponto existente em todo sonho e no qual ele é insondável, ponto de contato com o desconhecido.

Diante da aparição dessa imagem aterradora, o que se segue são indagações feitas por três personagens significativos para Freud, acerca do que seriam as questões fundamentais para ele: o sentido da neurose, seu tratamento e sua própria terapêutica. Por trás do Freud que sonha, tem-se também o psicanalista vienense a procura da chave do sonho, que deve ser a mesma que a chave da neurose e da cura: a palavra-chave do sonho é a própria natureza do simbólico (Lacan, 1954-1955/2010).

Assim, Lacan (1954-1955/2010) delimita como o ápice da segunda parte do sonho, resultado das falas e discussões dos personagens, a fórmula da trimetilamina. Com isso, a primeira parte do sonho culmina na imagem horrífica da garganta de Irma, na revelação do apocalipse e a segunda parte culmina nessa fórmula escrita, tal qual um oráculo.

Portanto, para Lacan (1954-1955/2010), é na fórmula da trimetilamina, que surge no sonho em letras garrafais, e na sequência da imagem aterradora da garganta de Irma, que se encontra a resposta do sentido do sonho. A resposta estaria, segundo ele, na própria forma enigmática e hermética em que a fórmula se anuncia. No momento de caos e de falas entrecortadas, surge a fórmula, essa palavra-chave, que consiste na própria natureza do simbólico. A fórmula da 
trimetilamina surge tal qual uma voz de ninguém, como “a derradeira palavra daquilo de que se trata, a palavra de tudo. Não quer dizer nada, senão que é uma palavra" (p. 232).

Bassols (2016) observa que Lacan, apontando a insistência do real na mancha branca na garganta de Irma, identifica o que não cessa de não se escrever no umbigo do sonho de Freud. A fórmula da trimetilamina, segundo as categorias modais lacanianas, é o que cessa de não se escrever, ou seja, através dessa fórmula, algo consegue se escrever.

Além disso, o sonho da injeção de Irma pode ser considerado como o primeiro grande índice da perspectiva inovadora da psicanálise a respeito do sexual (Teixeira, 2010). Essa questão é anunciada precisamente pela relação entre a imagem do fundo da garganta de Irma, a qual Lacan nos convoca a perceber como efeito do real, e a fórmula da trimetilamina. O gesto inaugural do saber psicanalítico está em interpelar a verdade do sexual no nível de seu enigma, colocando em evidência a questão do sexual como uma função de suspensão de sentido.

Segundo Teixeira (2010), o importante é que, ali onde o sexual se manifesta no sonho, na imagem disforme da carne, Freud não mais dispõe de um discurso significativo que se presta à produção de sentido. Aparece, pelo contrário, a fórmula da trimetilamina, cujo único recurso é a "literalização" de uma fórmula química. Assim, à pergunta pelo sentido do sexual sucede uma resposta: uma fórmula que não oferece explicação, refratária a toda intenção significativa, e cuja ausência de sentido consiste na própria resposta.

Sob o mesmo prisma, Teixeira (2010) retoma o caso da Sra. Emma Eckstein (Freud, 1950[1895]/1996h), com o intuito de elucidar o reposicionamento subjetivo de Freud a respeito da questão sexual. A Sra. Emma Eckstein é ninguém menos que a própria Irma do sonho da injeção de Irma, tendo Freud usado pseudônimos para manter a privacidade de sua paciente, o que foi revelado pelo historiador Max Schur (1982 citado por Teixeira, 2010) anos depois.

O mecanismo em jogo no caso da Sra. Emma Eckstein se refere a um quadro de evitamento histérico, associado à impossibilidade de entrar só em uma loja por conta de uma ideia, imposta involuntariamente, de estar sujeita ao riso dos vendedores. Teixeira (2010) aponta que a compreensão do sentido do sintoma 
torna-se fonte de erro, uma vez que a consciência de Emma recolhe uma falsa premissa (próton pseudos) ao considerar como motivo de seu temor uma lembrança vivenciada aos doze anos de idade. Apenas mais tarde Emma se recorda de uma cena, a qual se atribui a origem do sintoma: aos oito anos de idade, ao entrar em uma loja, Emma foi abordada sexualmente por um dos vendedores, e, ao abordá-la, o vendedor ria. Posteriormente, Emma retorna à loja, o que lhe trouxe sentimentos de reprovação.

O aspecto importante deste caso, destacado por Teixeira (2010), está no fato de Freud dar relevo ao fator econômico-quantitativo para compreender o mecanismo do sintoma histérico de Emma, em detrimento do valor semântico da ideia compulsiva. Freud descobre que o que dá inteligibilidade ao mecanismo do sintoma histérico de Emma está para além de um suposto sentido atribuído à representação patológica. Assim, foi preciso recompor as verdadeiras conexões que determinavam o sintoma de Emma, que devia sua origem a outra representação "hiperinvestida libidinalmente", e que recebeu sua significação sexual apenas a posteriori.

Teixeira (2010) observa que, a partir do caso Emma, a consideração das conexões causais do sintoma histérico deve ser definida, não pela significação das representações psíquicas, mas pela intensidade da carga afetiva ligada às representações. Segundo o autor, essa formulação, longe de obscurecer o fenômeno clínico, possibilita a inteligibilidade de suas conexões causais, devendo ser enfatizada a carga de energia libidinal, da qual as ideias são acidentalmente investidas ao longo da história do sujeito.

Com o intuito de elucidar a importância do sonho da injeção de Irma para a questão da histeria, retomamos André (1998), que afirma que este sonho revela para Freud o verdadeiro objeto das queixas de Irma. Nesse sentido, esse algo de inominável que aparece no fundo da garganta de Irma indica o caminho para a compreensão das queixas da paciente. Vislumbra-se aqui a ideia de que Irma se queixa de algo de inominável que surge "no lugar" de seu corpo. André (1998) afirma: "alguma coisa que faz com que seu corpo apareça como dessexualizado, desfalicizado, reduzido a um estado de carne desfigurada, de coisa - de objeto, dirá mais tarde Lacan” (p. 52).

Essa presença de algo de inominável no centro das queixas histéricas remete a dois casos clínicos de histeria relatados por Freud e Breuer em Estudos 
sobre a histeria (1893-1895/1996). Nos casos clínicos de Emmy von N. e Anna O., o inominável surge no discurso das pacientes por meio da temática da morte e impõe a interrupção da fala das pacientes, sendo responsável pelo sintoma de emudecimento de ambas.

O tema da morte e o mutismo remetem a um furo no discurso, a uma lacuna no tecido significante. Reencontra-se esse tema da lacuna no Rascunho $K$ de Freud (1950[1896]/1996b) com a noção de "lacuna psíquica". Nele, Freud traz uma definição da origem da histeria com base na ideia de ausência de representação, distinguindo-se da etiologia da histeria de 1894 a respeito da representação irreconciliável. Aqui, Freud defende que o fenômeno primário da histeria é "uma manifestação de susto, acompanhada por uma lacuna psíquica” (p. 282).

Além disso, torna-se importante dizer que a definição descrita no Rascunho K (Freud, 1950[1896]/1996b) e a citada na primeira parte do trabalho não são irreconciliáveis. No Rascunho L, Freud (1950[1897]/1996e) relaciona ambas, tratando a lacuna psíquica mais como algo da pré-história da histeria, sendo a lacuna e o susto psíquico anteriores ao sintoma histérico propriamente dito. Segundo Serge André (1998):

O significante que, num segundo tempo, vai constituir a "representação irreconciliável" é escolhido por estar de alguma forma à beira do furo, que ele delimita - o furo, em si mesmo, não pode ser de fato recalcado pois que ele é apenas furo e só o significante (a representação, diz Freud) pode ser recalcado. (p. 61)

Essas duas noções - a lacuna e a representação-limite - não foram retomadas posteriormente nos trabalhos de Freud sobre histeria (André, 1998). Elas apontam para aquilo que, mais tarde, Freud tentará demarcar com o homem dos lobos: a presença de um elemento real, fora do conhecimento porque fora do significante, no cerne do recalcamento significante que determina os sintomas, isto é, a insistência do real.

A histérica tenta dar conta desse encontro com algo de inominável por meio do registro do significante, através de uma série de lembranças, fantasias e alucinações. Percebe-se esse encontro com algo de inominável em fenômenos histéricos que encenam a passagem do inanimado ao animado ou o inverso. Nestes casos, o que ocasiona o sintoma é a percepção da mutação brusca de algo 
em estado animado ao estado de inanimado e vice-versa. Há como que a mutação da coisa real para a coisa significante que corresponde ao recobrimento do real pelo significante. No caso de Anna O., observa-se este fenômeno em uma visão na qual o braço de uma cadeira se transforma em uma serpente. Emmy, por sua vez, apresentava uma incapacidade de estender a mão ao cumprimentar pessoas por recear vê-la transformar-se em um animal terrível (André, 1998).

Aqui, André (1998) aponta que o valor traumático destes encontros com uma coisa morta ou com este corpo inanimado parece estar ligado à irrupção da função real, orgânica, do corpo, à queda do que se produz do erótico ao funcional, sendo isto que repugna a histérica. Estes casos apontam para uma presentificação de um estado do corpo, de cadáver ou carne em decomposição, à passagem súbita de um estado de coisa para o estado de corpo.

É o exemplo do caso de Anna O., que desenvolve um sintoma histérico ao assistir um cão bebendo água em um copo. Esse episódio se relaciona com a problemática da repulsa histérica. No momento em que a função erótica da sede, isto é, do desejo, é rebaixada ao nível da necessidade, ocorre a reação de repulsa. É como se a função humana do corpo fosse destruída. As atividades de beber, comer, respirar tornam-se, no humano, atividades eróticas que o corpo realiza, apoiadas mais na fantasia, sustentáculo do desejo, que na exigência do organismo (André, 1998).

André (1998) traz também o caso de Dora, que desenvolve repulsa do beijo do Sr. K: "quando os lábios e a boca se reduzem à mucosa superior do canal digestivo, um beijo se torna algo de absolutamente obsceno e intolerável” (p. 98). Mais tarde, essa reação de repulsa tornar-se-á o próprio critério definido por Freud (1905/1996m) para o diagnóstico da histeria.

Assim, a histeria desperta a discussão de como a sexualização atinge o corpo, de como se dá a fronteira entre o sexual e o não-sexual e de como se pode constituir as relações entre essas duas vertentes do corpóreo (André, 1998). 


\section{3 Histeria, sexualidade infantil e imagem corporal}

O presente capítulo tem como principais eixos teóricos os conceitos de sexualidade infantil, narcisismo e identificação, que são articulados para pensar sobre a neurose histérica e a relação com o corpo. Abordamos o caso clínico Análise fragmentária de uma histeria (1905[1901]/2016), a fim de poder nos deter sobre os conceitos e relacioná-los com um exemplo clínico. Ressaltamos, sobretudo, dois pontos do caso Dora, a saber, a prevalência da oralidade em sua histórica clínica e sintomas corporais e a problemática identificatória que aponta para uma questão sobre a feminilidade.

\section{1}

\section{Sexualidade infantil e corpo erógeno}

No capítulo anterior, apresentamos a sexualidade do modo como foi desenvolvida nos escritos freudianos desde os Estudos sobre a histeria, observando que Freud parte da concepção de um trauma sexual infantil para a apreensão da sexualidade enquanto traumática como propulsora do quadro histérico.

Após esse momento inicial, em que o trauma é princeps na etiologia da histeria, observa-se que Lacan denomina essa passagem da obra freudiana como sendo a concepção do trauma como contingência, isto é, quando se faz o abandono da noção da existência de um trauma sexual na infância do sujeito para a compreensão de que a estrutura da sexualidade é, ela própria, independente dos acontecimentos históricos, fundamentalmente traumática (Jorge, 2005).

Assim, em 1905, Freud formaliza a concepção psicanalítica da sexualidade humana a partir do artigo Três ensaios sobre a teoria da sexualidade. Este ensaio é composto por três partes: (1) as aberrações sexuais; (2) a sexualidade infantil; e (3) as transformações da puberdade. Trabalharemos principalmente os dois primeiros ensaios, uma vez que o assunto abordado no terceiro se distancia do tema da dissertação.

Segundo Garcia-Roza (1985), a partir desse manuscrito, Freud inaugura uma teoria sobre a sexualidade que não se mantém no interior da mesma sintaxe 
dos saberes vigentes de sua época. Ele toma como ponto de partida o discurso dos saberes existentes sobre a sexualidade e não apenas o contradiz e o refuta. Com o primeiro ensaio, nomeado "As aberrações sexuais", Freud busca perverter os discursos da psicopatologia da época sobre a sexualidade, que se assentavam todos na noção de instinto. Com isso, o psicanalista vienense inaugura o conceito psicanalítico de pulsão e demonstra a sexualidade infantil como sendo perversopolimorfa.

Jorge (2005) sublinha a descoberta apresentada neste ensaio de 1905 como sendo fundamental para enfatizar o caráter extremamente diverso da sexualidade humana, descoberta esta que surge através das experiências clínicas com pacientes neuróticos. Através da escuta psicanalítica, Freud apreende a ocorrência de uma sexualidade que se manifesta por meio de uma aparência errática à lógica que rege os instintos animais.

Em 1905, Freud introduz pela primeira vez o termo alemão Trieb, cuja tradução para o português ficou consagrada como "pulsão". Laplanche \& Pontalis (1992/1967) apontam que, antes da formalização deste conceito, Freud já tratava da noção energética de excitação (Reiz) a que o organismo está submetido, sendo esta a origem da noção de pulsão.

Em 1905, portanto, é formulado o conceito de Trieb, que se diferencia de Instinkt. A distinção entre ambos torna-se fundamental, uma vez que o instinto caracteriza o comportamento animal, que designa uma conduta hereditariamente fixada e visa a um objeto específico, ao passo que a teoria da pulsão tem como um dos seus pontos centrais a variação do objeto e de sua meta (Garcia-Roza, 1985).

Desse modo, a partir de um estudo mais aprofundado da sexualidade humana, Freud (1905/1996m) elabora uma teorização divergente do discurso da ciência de sua época. Àquela altura, no começo do século XX, a sexualidade era considerada um elemento ausente na infância, aparecendo somente na puberdade, e a meta da sexualidade seria a união sexual entre dois indivíduos de sexo oposto com fins de reprodução.

Freud (1905/1996m) desconstrói a ideia vigente sobre o instinto sexual que se harmonizava com a fábula segundo a qual o ser humano é dividido em duas metades, homem e mulher, que buscam unir-se no amor. Para compreender a especificidade da sexualidade humana, Freud propõe a denominação de objeto sexual à pessoa que desperta atração sexual, e meta sexual à ação para a qual a 
pulsão impele. Com relação a ambos, objeto e meta sexual, Freud constata um desvio na sexualidade humana.

No que tange ao objeto sexual, Freud verifica que a relação entre a pulsão sexual e o objeto sexual não é nem estreita e nem fixa. O autor escreve: "É provável que o instinto sexual, seja, de início, independente de seu objeto, e talvez não deva sequer sua origem aos atrativos deste" (p. 37-38). Assim, para a psicanálise freudiana, o objeto sexual é variável, isto é, a pulsão sexual admite variação quanto ao seu objeto de satisfação.

No que se refere à meta sexual, era considerado normal a união dos genitais no ato da copulação. Freud (1905/1996m), em direção oposta, constata ser possível observar elementos do que era considerado perversão na vida sexual normal. Assim, Freud demonstra como a fronteira entre o normal e o patológico não se configura como nítida e sólida. $\mathrm{O}$ autor aponta dois elementos característicos da vida sexual normal que se relacionam às perversões. O primeiro diz respeito às extensões anatômicas das áreas do corpo destinadas à união sexual, isto é, à meta sexual que raramente se limita apenas aos genitais, alastrando-se por todo corpo. O segundo se refere a uma tendência dos sujeitos a permanecer nos atos preparatórios do ato sexual, sem chegar ao ato genital de fato, podendo se desdobrar em novas metas e objetivos sexuais.

No presente estudo não será feita uma análise detalhada deste manuscrito de Freud, mas iremos circunscrever alguns pontos que consideramos importante para a compreensão da neurose histérica. Nesse sentido, em 1905, Freud afirma com veemência que as psiconeuroses se assentam em forças pulsionais, isto é, a energia da pulsão sexual não apenas contribui para os sintomas neuróticos, mas é a única constante e a mais importante fonte de energia da neurose. Nas palavras de Freud (1905/1996m): “a vida sexual das pessoas em questão se manifesta ou exclusivamente ou predominantemente ou apenas em parte nesses sintomas [...], os sintomas são a atividade sexual dos doentes" (p. 60).

Desse modo, Freud (1905/1996m) afirma que os sintomas das psiconeuroses representam um substituto para impulsos da pulsão sexual. Freud exemplifica esse ponto a partir de uma descrição da problemática sexual na neurose histérica. Este quadro clínico apresenta repressão sexual intensificada, isto é, uma forte resistência à pulsão sexual, que se manifesta nos sentimentos de vergonha, nojo e moral. Com isso, há uma fuga ante a consideração do problema 
sexual que, em casos acentuados, provoca completa ignorância desta problemática. Ao mesmo tempo, esse traço pode ser ocultado por outro fator constitucional da histeria, que consiste em um forte desenvolvimento da pulsão sexual. Eis o que Freud denomina de "contraditório enigma da histeria", que se deve ao par de opostos constituído por uma exacerbada necessidade sexual e uma intensa rejeição da sexualidade.

O autor ainda sublinha que é o componente sexual do conflito que possibilita o adoecimento neurótico. O motivo facilitador da doença ocorre quando o individuo é confrontado com as exigências reais da sexualidade, isto é, um conflito entre a pressão da pulsão sexual e o antagonismo da rejeição da sexualidade, sendo os sintomas uma maneira de escapar do conflito, sem, contudo, resolvê-lo.

Freud (1905/1996m) não só aponta que os sintomas representam um substituto de impulsos da pulsão sexual, ele afirma, também, que representam a expressão convertida de impulsos perversos. O autor aproxima a perversão da psiconeurose, contudo, assinalando a diferença entre o que denomina de perversão positiva e negativa. Desse modo, na perversão, as fantasias perversas se apresentam de forma consciente e, na psiconeurose, trata-se de fantasias perversas inconscientes. Nas palavras do autor, "a neurose é, digamos, o negativo da perversão" (p. 63).

Assim, Freud (1905/1996m) postula a existência de uma predisposição perverso-polimorfa em todo sujeito. Esta predisposição se apresenta na infância, quando se pode encontrar as raízes da pulsão sexual, seus traços essenciais e as condições fundamentais da vida sexual. O autor afirma que esta predisposição se apresenta em todos os seres humanos, podendo apresentar diferenças em seu percurso na vida sexual comum, nas psiconeuroses e nas perversões. Segundo Freud,

trata-se de raízes inatas, constitucionais, do intenso sexual, que numa série de casos se desenvolvem até se tornarem os autênticos veículos da atividade sexual (perversões), e outras vezes sofrem uma supressão (repressão) insuficiente, de modo a poder atrair para si, por via indireta, como sintomas de doença, uma parte considerável da energia sexual, enquanto nos casos mais favoráveis, entre os dois extremos, podem dar origem, por meio de uma restrição eficaz e de outras formas de elaboração, à assim chamada vida sexual normal (p. 72) 
Esta predisposição, que contém as raízes constitucionais da pulsão sexual, consiste no que Freud denominou de sexualidade infantil. Esta concepção foi energicamente criticada pelo meio médico da época, devido a uma confusão entre "sexual" e "genital". É preciso ressaltar que a noção de sexualidade para a psicanálise é concebida de forma ampliada, não se restringindo à sexualidade genital, como se pode ver nas teorizações de 1905.

Nesse sentido, Freud (1905/1996m) caracteriza a sexualidade infantil como autoerótica, isto é, a pulsão não se dirige para um objeto externo, mas, pelo contrário, satisfaz-se no próprio corpo. A pulsão, portanto, é constituída por diversas pulsões parciais que se vinculam a excitações de regiões do corpo. Entre as manifestações sexuais infantis, Freud elege como modelo o ato de chupar sem finalidade de alimentação. Este ato se caracteriza por uma busca de prazer que encontra satisfação, por exemplo, no ato de sugar uma parte da pele ou da mucosa. Esta busca de prazer, contudo, visa a um prazer já experimentado, o qual a criança se empenha em renovar. Assim, a primeira experiência de prazer ocorre no ato de mamar no peito da mãe ou seu substituto.

Nesse exemplo, os lábios da criança funcionam como zona erógena que, em um primeiro momento, tem sua satisfação relacionada à satisfação da necessidade de alimento. Com isso, Freud (1905/1996m) postula que a atividade sexual primeiramente se apoia em uma função vital do corpo como, por exemplo, a necessidade de alimento e, posteriormente, se torna independente, como no ato de chupar.Assim como a zona oral dos lábios, a zona anal também é caracterizada como uma zona erógena, cuja sexualidade advém a partir do apoio nas funções excretórias vitais do corpo. A atividade vital ligada à zona anal permite uma estimulação e excitabilidade desta área. Além disso, o conteúdo intestinal adquire significados importantes para o bebê, o qual trata a massa fecal como uma parte do próprio corpo, simbolizando seu primeiro "presente", ou seja, por meio da liberação ou retenção dele, o bebê pode expressar docilidade ou desobediência com as pessoas que dele cuidam.

$\mathrm{O}$ autor aponta que as crianças que possuem forte significação erótica da oralidade podem, quando adultos, desenvolver intensa apreciação de atividades que envolvam essa zona erógena, como, por exemplo, o ato de beijar ou atividades de fumo. Sobrevindo a repressão, contudo, podem sentir nojo de atividades ligadas à zona dos lábios, isto é, nojo de alimentos, que pode levar à 
produção de vômitos histéricos. Trata-se aqui da dupla destinação da zona labial e das áreas do corpo. Esta questão será tratada mais à frente sob a luz do caso clínico de Dora.

Freud (1905/1996m) afirma que a criança que chupa procura em seu corpo e escolhe algum ponto para sugar com deleite, podendo este se tornar seu ponto preferido. Segundo o autor, essa capacidade de deslocamento é análoga à que se apresenta na sintomatologia histérica. Nesta última, o recalque atinge principalmente as zonas genitais, concedendo sua excitabilidade a outras zonas erógenas, que se comportam como genitais. Além disso, o autor afirma que, entre as psiconeuroses, a neurose histérica apresenta mais notadamente a significação das zonas erógenas "como aparelhos subordinados e sucedâneos dos genitais" (p. 68).

O psicanalista vienense define as zonas erógenas como "uma parte da pele ou mucosa em que estímulos de determinada espécie provocam uma sensação de prazer de certa qualidade" (1905/1996m, p. 87). A respeito da qualidade dos estímulos geradores de prazer, Freud afirma não ter conhecimento exato, mas assinala o caráter sexual e rítmico destes estímulos como definitivos para sua especificidade.

A meta sexual da pulsão infantil consiste em gerar satisfação por meio da estimulação, satisfação esta já vivenciada anteriormente, o que ocasiona a necessidade de ser repetida. Esta necessidade de repetição se manifesta através de uma sensação de tensão, que se apresenta como desprazer, e de uma sensação de "comichão" ou estímulo centralmente condicionado, que se projeta na zona erógena periférica. Com isso, a meta sexual visa "substituir a sensação de estímulo projetada, na zona erógena, pelo estímulo externo que anula a sensação de estímulo, ao gerar a satisfação" (p. 90).

Freud afirma, em 1915, em Os instintos e seus destinos, que a investigação das vicissitudes das pulsões deve ser realizada por meio do estudo das pulsões sexuais, uma vez que se tem mais conhecimento destas. $\mathrm{O}$ autor aponta algumas qualidades das pulsões sexuais: elas são numerosas, advêm de múltiplas fontes orgânicas, atuam, de início, de forma independente umas das outras e, apenas ulteriormente, são reunidas em uma síntese mais ou menos completa. A meta visada por cada uma delas consiste no prazer do órgão, e somente depois de realizada a síntese, elas entram a serviço da função reprodutiva. Além disso, 
podem trocar facilmente de objetos e suas realizações podem se achar afastadas de seus objetivos iniciais, como, por exemplo, em um dos destinos da pulsão, a sublimação.

A respeito da noção de prazer do órgão, Laplanche e Pontalis (1992/1967) observam que esta noção condensa, de certo modo, os traços que definem a sexualidade infantil. Freud (1915/2013) utiliza este termo para designar a modalidade de prazer característica da satisfação autoerótica das pulsões parciais, ou seja, a ideia de que a excitação de uma zona erógena é aplacada no próprio lugar no qual desponta. Isso ocorre de forma independente das outras zonas e sem relação direta com uma função biológica.

Freud pontua, em 1905, que existem certas zonas erógenas pré-destinadas, como se observa no ato de chupar. Entretanto, outras partes do corpo podem servir de zona erógena quando possuem aptidão para isto. $\mathrm{O}$ autor observa que a sensação de prazer decorre mais da qualidade do estímulo que da localidade do corpo. Segundo o autor, "a propriedade erógena pode se ligar a certas partes do corpo de maneira notável" (1915/2013, p. 88). Desse modo, em 1905, o autor concebe certas localidades do corpo como sendo mais suscetíveis à excitação sexual. Em 1915, no entanto, Freud modifica tal concepção e afirma, em uma nota de rodapé, que reflexões subsequentes levaram-no a atribuir a "propriedade da erogeneidade a todas as partes do corpo e todos os órgãos internos” (1915/2013, p. 89).

Em 1915, portanto, Freud revisita o manuscrito dos Três ensaios sobre a teoria da sexualidade a fim de trazer novas contribuições para o estudo. Cabe salientar que, apenas em 1915, a noção de organização pré-genital infantil aparece de forma mais efetiva, sendo caracterizada por uma etapa do desenvolvimento sexual da criança marcada por uma organização da libido designada por uma zona erógena predominante ou por um modo de relação de objeto. Em outras palavras, em 1915, Freud admite que a sexualidade se organiza em torno de zonas prevalentes antes de alcançar uma organização em torno da zona genital. Além disso, inicialmente, Freud distingue duas fases dentre as organizações prégenitais, a fase oral ou canibal e a sádico-anal. Apenas em 1923, ele acrescenta uma terceira fase pré-genital, a fase fálica, que, apesar de genital, reconhece apenas o genital masculino (Garcia-Roza, 1985). 
No que tange à noção de zona erógena, torna-se importante destacar que este conceito implica que o corpo da criança tenha sido alvo de investimentos libidinais, a que Freud se refere em 1915 a partir da noção de sedução. É a partir dos investimentos do outro materno que o corpo da criança torna-se erógeno e se constitui como um corpo próprio, habitado pela linguagem. As zonas erógenas, portanto, são caracterizadas como orifícios de troca que constituem condições de possibilidade para a estruturação do sujeito a partir da sexualidade. Nesse sentido, Lacan (1975-1976/2007) afirma que "as pulsões são, no corpo, o eco do fato de que há um dizer [...]. Esse dizer para que ressoe, para que consoe [...], é preciso que o corpo lhe seja sensível” (p. 18). Nesse sentido, a pulsão se instaura no corpo a partir do Outro, da sua palavra, do uso da linguagem.

Rudge (1998) retoma o mito da constituição da pulsão sexual descrito por Freud no Projeto para uma psicologia científica. O autor não utiliza o termo “pulsão", mas trata deste termo a partir da palavra "desejo". Segundo Freud (1950[1895]/1996h), a experiência de satisfação da necessidade, realizada por meio do contato com um semelhante, permite o surgimento de facilitações, caminhos privilegiados que constituem um roteiro da pulsão sexual. Através do corpo do semelhante, são inscritas as marcas da historia de cada sujeito.

Assim, a ideia de um corpo, visto em seu conjunto como um corpo erógeno, o descarta da anatomia médica e o torna um corpo de desejo, aberto ao outro e representando as pulsões sexuais. Segundo Naves (2007), é este corpo que atesta a histérica, como Freud averigua desde os Estudos sobre a histeria. A dor nas pernas de Elisabeth von R. não diz respeito à perna enquanto órgão locomotor, mas ao que ela representa em sua função imaginária.

Em 1910, no artigo Concepção psicanalítica da perturbação psicogênica da visão, Freud traz algumas contribuições importantes para a concepção do corpo erógeno a partir da análise de um sintoma conversivo. Nesse sentido, o autor afirma que os órgãos e sistemas de órgãos do corpo se encontram à disposição, tanto das pulsões sexuais quanto das pulsões do Eu e, nesse sentido, servem a dois senhores ao mesmo tempo. Nesse momento da teoria pulsional, é apresentado o primeiro dualismo pulsional, envolvendo uma dualidade entre a pulsão sexual e a pulsão de autoconservação, ou seja, expressando uma oposição entre "amor" e "fome", como nas palavras do poeta Schiller. O sintoma histérico, portanto, nesta perspectiva, advém do fato de um grupo de ideias entrarem em oposição a outras 
ideias mais fortes e vinculadas ao Eu, provocando o recalque. Estas ideias, contudo, expressam uma luta entre pulsões: pulsões que servem à sexualidade e à obtenção de prazer sexual e pulsões que têm por meta a autoconservação, as pulsões do Eu.

O distúrbio psicogênico da visão, a cegueira histérica, é provocado pelo recalque do prazer erótico de olhar. Este órgão que serve à percepção sensorial conduz-se como um genital, uma vez que há um aumento do seu papel erógeno por consequência do recalque. Freud sublinha que isso ocorre devido a uma dupla solicitação de um órgão, que serve tanto à necessidade quanto ao desejo. Segundo o autor,

o prazer sexual não se acha ligado apenas à função dos genitais, a boca serve tanto para o beijo como para a alimentação e a comunicação, os olhos percebem não apenas as alterações no mundo exterior que são importantes para a preservação da vida, mas também as características dos objetos que os tornam elegíveis como objetos de amor, seus "encantos". (Freud, 1910/2013, p. 319)

Os sintomas histéricos, portanto, consistem em formações substitutivas do recalcado, que se referem a uma compensação, uma espécie de vingança, para a pulsão recalcada, que, impedida de maior avanço psíquico, aumenta seu domínio sobre o órgão que a serve. O sintoma como formação substitutiva é consequência do recalque malogrado e, no caso da cegueira histérica, trata-se do recalque do prazer em olhar. Freud (1910/2013) ilustra essa concepção, afirmando que é como se uma voz punitiva dissesse ao individuo "porque você pretendia utilizar seu órgão da visão para um mau prazer sensual, é bem feito que não consiga mais enxergar" (p. 321).

\section{2}

\section{O conceito de pulsão em Freud e Lacan}

Em 1915, no ensaio Os instintos e seus destinos, Freud define o conceito de pulsão a partir de outros ângulos. $\mathrm{O}$ autor discute a ideia da pulsão se referir a um estímulo para a psique, logo advertindo a impossibilidade de equiparar estímulo e pulsão. Um estímulo (fisiológico) que age sobre a psique opera como um impacto único, podendo ser eliminado através de uma ação por parte do sujeito como uma fuga motora diante de um estímulo, por exemplo, o ato de esquivar-se quando uma luz forte bate no olho. 
A pulsão, de outra parte, não provém do mundo exterior, mas do interior do próprio corpo, impossibilitando uma fuga por movimentos musculares e colocando exigências mais elevadas ao aparelho nervoso. A pulsão, portanto, atua como uma força constante, impossibilitando que o aparelho nervoso mantenha os estímulos à distância, uma vez que sustentam um inevitável e incessante afluxo de estímulos. Segundo o autor, a pulsão

nos aparece como um conceito-limite entre o somático e o psíquico, como o representante psíquico dos estímulos oriundos do interior do corpo e que atingem a alma, como uma medida do trabalho imposto à psique por sua ligação com o corpo. (Freud, 1915/2010b, p. 57)

Assim, ao invés de conceber a pulsão como um estímulo para a psique, Freud afirma que a pulsão atua como uma medida de exigência de trabalho à psique.

São quatro os atributos mais importantes da pulsão: impulso, meta, objeto e fonte. O impulso consiste no seu elemento motor, sua força, a medida de trabalho que a pulsão representa; a meta, por sua vez, é a satisfação; o objeto é aquele pelo qual a pulsão obtém sua meta, não está ligado à pulsão e é variável; por fim, a fonte se refere a um processo somático em um órgão ou parte do corpo.

Lacan (1964/2008a) propõe uma análise séria da noção de pulsão elaborada por Freud. O psicanalista francês sublinha que este conceito não se encontra no registro do orgânico, tampouco se totaliza pela referência ao conceito de fixação, cunhado por Freud, e também não se confunde com o impulso, Drang, que consiste em apenas um dos termos da pulsão. Freud, ao apontar os quatro termos da pulsão, ou seja, o impulso, a fonte, o objeto e o alvo, poderia dar a entender que se trata de um processo natural, orgânico. Contudo, é justamente essa apreensão equivocada que Lacan busca refutar, demonstrando que todo texto freudiano aponta para um afastamento da noção de pulsão como algo orgânico.

Segundo Lacan (1964/2008a), em seu artigo de 1915, Freud designa o conceito de pulsão como um Grundbegriff, um conceito fundamental. Lacan destaca o termo Konvention utilizado por Freud para se referir à pulsão, que estaria próximo da noção de ficção, que Lacan elege para designar a pulsão, isto é, uma ficção fundamental.

Desse modo, o autor retoma os quatro termos da pulsão descritos por Freud em 1915 e faz uma análise detalhada de cada um deles, que só se 
apresentam de forma disjunta. O impulso, por sua vez, diz respeito a uma tendência, pura e simplesmente, à descarga. Esta tendência é produzida por um estímulo, por uma transmissão de um suplemento de energia, que Freud (1950[1895]/1996h) nomeia no Projeto para uma psicologia científica como a quantidade $Q n$. O impulso se refere também à estimulação, excitação, nível ao qual Freud utiliza o termo Reiz, que quer dizer "excitação". Contudo, o Reiz característico da pulsão se distingue do Reiz concernente ao mundo exterior, pois consiste em um Reiz interno.

De acordo com o psicanalista francês, Freud busca distinguir fundamentalmente a pulsão de uma pressão da necessidade, como nos exemplos da fome ou da sede. Além disso, é preciso se distanciar, quando se trata da pulsão, da ideia de um organismo em sua totalidade, em seu estado de conjunto, em que o vivo está interessado. Não se trata disso. Trata-se de um campo que Freud apresenta desde o Esboço de psicanálise (1940[1938]/1996q), o do Real-Ich. Lacan aponta que o Real-Ich é suportado não pelo organismo inteiro, mas pelo sistema nervoso. Esse ponto interessa, pois, topologicamente, trata-se de uma superfície, que é investida pulsionalmente. Esse investimento aponta para uma energia potencial, que se refere à característica da pulsão de ser uma força constante.

Nesse sentido, a constância do impulso possui uma particularidade própria e se distingue de uma função biológica, a qual possui sempre um ritmo, e de uma energia cinética, que é regrada pelo movimento. A descarga da pulsão se situa em um plano inteiramente diferente. Como afirma Lacan (1964/2008a), Freud aponta exatamente que a pulsão não possui dia e noite, primavera ou outono, não tem subida e descida.

No tocante à satisfação da pulsão, o autor traz considerações importantes. Segundo o psicanalista francês, nos textos freudianos, observamos que a satisfação da pulsão consiste em atingir o alvo. Contudo, esta definição pode ser compreendida equivocadamente como no movimento de um animal que obtém satisfação ao alcançar seu alimento. Não se trata disso e, para contestar tal concepção, Lacan retoma o conceito freudiano de sublimação, que consiste em uma das vicissitudes e uma das possibilidades de satisfação da pulsão, sendo esta inibida em seu alvo. Assim, é possível satisfazer a pulsão através da sublimação, e isto sem que o recalcamento esteja em jogo. Em suma, segundo Lacan 
(1964/2008a), “o uso da função da pulsão não tem para nós outro valor senão o de pôr em questão o que é da satisfação" (p. 164).

O psicanalista francês pontua que é no nível da pulsão que deve ser retificado o estado de satisfação. Esta última possui um paradoxo. $\mathrm{O}$ sujeito não se contenta com o estado em que se encontra, não se contenta com o que é, no entanto, estando nessa condição pouco satisfatória, ele se contenta assim mesmo, isto é, tudo o que vive, inclusive seus sintomas, depende da satisfação. Assim, afirma que algo está se contentando aí, resta saber o quê. Segundo Lacan (1964/2008a), “eles satisfazem algo que vai sem dúvida ao encontro daquilo com o que eles poderiam satisfazer-se, ou talvez melhor, eles dão satisfação $a$ alguma coisa" (p. 164). Aqui, trata-se do princípio do prazer, pois, através do desprazer, a lei do princípio do prazer é alcançada, ou seja, o sofrer demais levando a uma espécie de satisfação.

O paradoxo da satisfação inclui a noção de impossível. Lacan (1964/2008a) aponta o real como o oposto do possível, sendo este o que separa o campo do princípio do prazer, através da dessexualização - separação que ocorre, pois sua economia admite o impossível. O impossível está presente, contudo, também no outro campo, no princípio do prazer.

Com isso, o objeto da pulsão é fundamentalmente distinto do objeto da necessidade, o qual não pode satisfazer a pulsão. Em outras palavras, não é pelo alimento que a boca se satisfaz, mas sim pelo prazer da boca. Lacan (1964/2008a) sublinha que Freud, em 1915, postula que o objeto da pulsão é indiferente. Sendo assim, o objeto da pulsão oral, por exemplo, consiste no seio, e não no alimento, na lembrança do alimento ou nos cuidados maternos. Com isso, torna-se importante revisitar a função de objeto e, desse modo, o seio, em sua função de objeto, se refere a um objeto $a$, causa do desejo, e a pulsão o contorna.

Por fim, relativamente à fonte da pulsão, ou seja, de onde parte a pulsão, Lacan (1964/2008a) lembra que as zonas erógenas são reconhecidas por sua estrutura de borda, como, por exemplo, no caso da zona oral, têm-se a boca, os lábios, os dentes e não outros órgãos que participam da ingestão de alimento, como o estômago e o esôfago.

A estrutura da borda das zonas erógenas pode intervir nessa zona de queda que Lacan (1964/2008a) nomeia de dessexualizacção. Isso ocorre quando o objeto sexual desliza e se apresenta como um pedaço de carne. Podemos ver esse 
fenômeno na histeria, nas reações de desgosto. Na queda da sexualização, há duas grandes vertentes do desejo, ou seja, de um lado, o desgosto provocado pela redução do parceiro sexual a uma função de realidade, e, de outro lado, tem-se a inveja.

Outro ponto importante destacado por Lacan (1964/2008a) se refere à definição de pulsão como uma montagem. O autor aponta que esta montagem, de saída, se evidencia como "sem pé nem cabeça", como uma montagem surrealista. Por exemplo, em um mecanismo definido por um começo, meio e fim, com relação à pulsão tem-se a inversão de tal mecanismo. Assim, em uma montagem surrealista, tal como a "marcha de um dínamo acoplado na tomada de gás, de onde sai uma pena de pavão que vem fazer cócegas no ventre de uma bela mulher que lá está incluída para a beleza da coisa”, teríamos, em vez disso, não a reversão do dínamo, mas uma situação na qual "desenrolam-se seus fios, são eles que se tornam a pena de pavão, a tomada de gás passa pela boca da moça e pelo meio sai um sobre de ave" (Lacan, 1964/2008a, p. 167).

Nesse sentido, essas imagens possibilitam uma ilustração do que se trata na montagem da pulsão, como algo fundamentalmente distinto do corpo orgânico.

Além disso, o psicanalista francês formaliza uma concepção que pode ser encontrada no texto de Freud, segundo a qual as pulsões são, por excelência, pulsões parciais. Nesse sentido, com relação à finalidade biológica da sexualidade, à reprodução, as pulsões, tal como se evidenciam na realidade psíquica, são pulsões parciais. A sexualidade, portanto, se manifesta na forma de pulsões parciais. Segundo Lacan (1964/2008a), “a pulsão é precisamente essa montagem pela qual a sexualidade participa da vida psíquica, de uma maneira que se deve conformar com a estrutura de hiância que é a do inconsciente" (p. 173).

Desde os Três ensaios sobre a teoria da sexualidade, Freud (1905/1996m) indicou a sexualidade como essencialmente polimorfa, aberrante e, assim, rompe o encanto com a presumida inocência infantil. Freud aponta que a sexualidade se situa de forma equivalente em todos os sujeitos, desde a infância até a fase adulta. Isso ocorre uma vez que há uma imposição demasiadamente cedo da sexualidade, que pode inclusive ser cedo demais, segundo o autor. Além disso, ela só se exerce através das pulsões parciais, isto é, parciais no tocante à finalidade biológica da sexualidade, a reprodução. 
A discussão das pulsões é encoberta pela referência às pulsões sexuais, pois a pulsão somente representa, e parcialmente, como afirma Lacan (1964/2008a), “a curva da terminação da sexualidade no ser vivo" (p. 174). Com isso, o seu último termo é a morte, uma vez que a presença do sexo está ligada à morte.

Por fim, Lacan (1964/2008a) assinala que o ponto fundamental no nível da pulsão é a sua estrutura de vaivém. Esta concepção está em Freud, quando este se refere às vias ativas, passivas e reflexivas, ou como no exemplo de ver e ser visto, atormentar e ser atormentado. No texto freudiano, observa-se que o autor sempre se refere à ideia de que o percurso da pulsão não pode ser separado de seu vaivém, de sua reversão fundamental, o que diz respeito ao "caráter circular do percurso da pulsão" (p. 175).

\section{3 \\ O caso Dora}

Escolhemos abordar o caso Dora no presente trabalho em função de dois pontos em particular: um aspecto do caso que se refere diretamente à presença fundamental do corpo, no qual se acentuam os sintomas somáticos da paciente, mais especificamente a prevalência da oralidade; e outro ponto que consiste na problemática da identificação, característica da histeria, e, a nosso ver, igualmente importante para o tema dessa dissertação, qual seja, o de pensar o estatuto do corpo na histeria.

Com isso, no artigo denominado Análise fragmentária de uma histeria (1905[1901]/2016), Freud descreve o processo de análise de Dora, sendo este centrado na história de vida da paciente. Freud havia descoberto que a causalidade histérica encontra-se centrada na "vida psicossexual dos doentes". Assim, abandona a técnica que parte dos sintomas, buscando eliminá-los e decifrá-los um após o outro, pois esta se mostrou "inadequada à estrutura mais sutil da neurose" (p. 180).

Segundo Freud (1905[1901]/2016), esta mudança na técnica influenciou a maneira que ele pôde descrever o caso clínico e propiciou o título do artigo “Análise fragmentária de uma histeria". Assim, devido à recomendação feita à paciente para que esta determine o tema das sessões, o que o psicanalista obtém 
do seu discurso são "inestimáveis, ainda que mutilados, vestígios” (p. 181), fazendo alusão ao trabalho de um arquéologo. Freud descreve o relato de Dora como um discurso que deixa lacunas e enigmas, que contém nexos partidos e estabelece uma sequência ambígua de eventos. Nesse sentido, apesar de Freud se referir à nova técnica psicanalítica baseada na liberdade de associações do paciente, podemos relacionar esta descrição do relato de Dora com o que o autor aponta como um traço fundamental da neurose histérica, isto é, a posse de um discurso não linear e fragmentário sobre a sua história. Assim, em uma nota de rodapé, o autor traz um exemplo no qual verificou não se tratar de um caso de histeria quando a "narrativa se revelou perfeitamente clara e ordenada, não obstante a singularidade dos acontecimentos a que se referia” (p. 186).

Nesse sentido, descreveremos inicialmente a trama de relações em que Dora estava inserida no momento em que ela, uma jovem de dezoito anos, é levada pelo pai para se consultar com Freud. Não faremos um relato pormenorizado do caso, visto que este foi suficientemente comentado na literatura psicanalítica.

Com efeito, seu círculo familiar compreendia os dois genitores e um irmão, que era um ano e meio mais velho que ela. A trama de relações destacada por Dora nas sessões, contudo, era formada pela paciente, seu pai e um casal de amigos deste, a Sra. K e o Sr. K. Este quarteto era constituído por relações demasiadamente complexas entre cada personagem.

A trama se inicia em um período no qual o pai de Dora está enfermo e a Sra. K adquire papel importante em seus cuidados. Posteriormente, ela se torna amante do pai de Dora, relação esta que perdura por muitos anos. Paralelamente a isto, o marido da Sra. K passa a fazer ofertas amorosas à Dora, situação diante da qual seu pai fecha os olhos. Dora, contudo, percebe que é oferecida como objeto de troca ao Sr. K, para que a relação entre o seu pai e a Sra. K pudesse ser mantida.

Apesar disso, Freud (1905[1901]/2016) logo percebe a participação e a cumplicidade de Dora para favorecer a relação entre o seu pai e a Sra. K. A paciente cuidava das crianças do casal $K$, o que a deixava em uma posição de mãe para com elas e, ao mesmo tempo, impossibilitava que elas incomodassem seu pai e a Sra. K quando estivessem juntos. 
As relações entre esse quarteto se mantém durante anos até que, após uma proposta amorosa do Sr. K, que ficou conhecida como a "cena do lago", Dora passa a fazer exigências ao pai para que este deixe de encontrar a Sra. K e o Sr. K. Desenvolveremos mais adiante os desdobramentos desta ocorrência, que desencadeia mais notadamente o quadro histérico de Dora.

\subsection{1}

\section{O caso Dora e a prevalência da oralidade}

Sobre a sintomatologia de Dora, Freud (1905[1901]/2016) afirma que se trata de um caso de "Petite hystérie", ou seja, um quadro de sintomas somáticos e psíquicos mais comuns do que, por exemplo, os casos descritos em Estudos sobre a histeria. Freud afirma que os principais sintomas de Dora são os seguintes: dispneia, tosse nervosa, afonia, dores de cabeça, ânimo deprimido e insociabilidade histérica. Os sintomas de Dora evidenciam como "a história de seu desejo é vivenciada em seu corpo" (Naves, 2007, p. 33).

Segue-se a descrição feita pelo autor do quadro geral dos sintomas de Dora. Aos oito anos, a menina apresentou uma dispneia crônica que foi diagnosticada, à época, como um sintoma nervoso. Durante a infância, quando o irmão apresentava uma doença, ela manifestava a mesma com maior gravidade. Com doze anos, ocorreram-lhe dores de cabeça acompanhadas de ataques de tosse nervosa, que depois se manifestaram separadamente. Então, ao dar início ao tratamento com Freud, Dora apresentava os seguintes sintomas: tosse nervosa de longas durações, períodos de completa perda de voz, dispneia e ânimo deprimido. Além disso, dois episódios chamaram a atenção do pai, levando-o à decisão de encaminhá-la para as consultas com Freud: um episódio em que Dora deixou uma carta de despedida para os pais e quando, após uma discussão com o pai, Dora teve um acesso de perda de consciência.

Percebe-se no relato a prevalência da oralidade nos sintomas que Dora manifesta desde o período da infância: dispneia, afonia e tosse nervosa. Freud percebe que o trauma recente em sua história clínica desencadeia um estado patológico histérico em Dora, mas este não serve para determinar os sintomas e explicar suas peculiaridades. Deve-se, portanto, retroceder à infância. Nessa busca, Freud encontra a prevalência em Dora da zona erógena dos lábios e um 
posterior recalque desta zona erógena, o que permitiu o desenvolvimento de sintomas ligados à oralidade.

Freud (1905[1901]/2016) explica o desvio da sexualidade que ocorre nas psiconeuroses a partir de dois vieses: a constituição sexual, que inclui a hereditariedade, e os acidentes da vida. $O$ autor faz uma analogia entre a sexualidade dos neuróticos e os desvios do curso de um rio, afirmando que "as águas que encontram um obstáculo no leito do rio refluem para cursos antigos, que estavam destinadas ao abandono" (p. 229). Com isso, afirma que a força motora que provoca a formação de sintomas histéricos origina-se na sexualidade infantil recalcada e nos impulsos perversos inconscientes.

Podemos perceber aqui a relação com a noção de "fixação" cunhada por Freud. O autor afirma que a zona erógena oral se tornou fixa para Dora e, portanto, adequada para dar expressão a sua libido.

A respeito da sexualidade infantil de Dora, Freud (1905[1901]/2016) observa, a partir do relato da paciente, que durante um longo período de sua infância, ela havia cultivado o hábito de chupar o dedo. Dora havia sido uma chupadora, nas palavras do autor. Dora se recordava desse hábito e conservara a lembrança de uma cena de seus primeiros anos de vida, na qual estava sentada no chão, chupando o polegar esquerdo e, ao mesmo tempo, com a mão direita, puxava o lóbulo da orelha de seu irmãozinho.

Assim, Freud (1905[1901]/2016) aponta que a intensa atividade da zona erógena dos lábios de Dora havia sido precondição para a "complacência somática por parte do trato da mucosa que começa nos lábios" (p. 231). De forma tal que um sintoma histérico possui tanto origem psíquica quanto somática, fenômeno que Freud nomeia de "complacência somática", referindo-se à ocorrência de um evento ligado a um órgão do corpo. Segundo Lacan (1951/1998b), essa cena de Dora com o seu irmão dá "a matriz imaginária em que vieram desaguar todas as situações que Dora desenvolveu em sua vida” (p. 220).

Desse modo, a intensa atividade da zona erógena dos lábios e o recalque desta têm a seguinte consequência: "quando, numa época em que já se conhece o objeto sexual propriamente dito, o membro masculino, surgem circunstâncias que fazem aumentar novamente a excitação da zona erógena oral conservada”, o autor continua, "não se requer grande força inventiva para substituir o mamilo original e o dedo que o representa pelo objeto sexual atual, o pênis, na situação que conduz 
à satisfação" (Freud, 1905[1901]/2016, p. 231). Nessa passagem, Freud se refere às fantasias perversas inconscientes por trás dos sintomas histéricos, e, nesse caso, afirma que a impressão de mamar no peito pode ser substituída por uma fantasia perversa relacionada a chupar o genital masculino.

Com relação aos sintomas de garganta irritada e de tosse apresentados por Dora, Freud (1905[1901]/2016) observa que ambos estavam vinculados a uma fantasia inconsciente da paciente. Com estes sintomas, Dora "imaginava uma situação sexual per os [pela boca] entre as duas pessoas cuja relação amorosa ela se ocupava incessantemente" (p. 225-226). O autor se refere a uma fantasia sexual de Dora ligada ao intercurso sexual entre seu pai e a Sra. K. Freud se dá conta dessa cena fantasiada por Dora a partir do desdobramento de uma fala da paciente. Em uma sessão, Dora faz a afirmação de que a Sra. K amava seu pai apenas porque ele era um homem "de recursos". Por conta de certos detalhes da sessão e pela expressão de Dora, o autor percebe que esta frase indicava seu oposto, que seu pai era um homem "sem recursos". Então, ele percebe que esta fala deveria ser compreendida por meio de sua conotação sexual, indicando, portanto, que o pai de Dora era um homem sem recursos, ou seja, impotente. Dora tinha conhecimento da doença venérea de seu pai e que ele não poderia ter uma relação sexual pautada no órgão genital, portanto, imaginava que o intercurso sexual de seu pai com a Sra. K se dava através da satisfação pela boca.

Logo após a interpretação de Freud, o sintoma de tosse desaparece. Freud afirma, contudo, que um sintoma possui mais de um significado e representa vários cursos de pensamentos inconscientes, sendo esta fantasia sexual apenas uma das que determinam o sintoma.

Além disso, o recalque da zona erógena dos lábios também se relaciona a outros sintomas vinculados a essa área do corpo, que foram desencadeados após uma vivência traumática de caráter sexual, ocorrida aos catorze anos. Nesta experiência, o Sr. K criou uma situação para que Dora estivesse sozinha com ele em sua loja e, subitamente, aplicou-lhe um beijo em seus lábios. A paciente narra que, no momento do beijo, ela sentira um forte nojo, livrando-se do abraço e correndo para a porta da loja. Freud observa aqui o mecanismo de inversão de afeto, isto é, quando uma pessoa que vivencia uma situação que suscitaria excitação sexual, tem, pelo contrário, sensações desprazerosas. O psicanalista 
pontua então que toda pessoa que experimenta tal deslocamento de sensação pode ser considerada histérica, mesmo quando não apresenta sintomas conversivos.

Assim, em vez da sensação genital, ocorre em Dora a sensação desagradável característica da mucosa da entrada do canal digestivo, o nojo. Esta sensação de nojo passa a ser um sintoma permanente. Dora desenvolve uma aversão à comida e uma sensação de pressão que ela relaciona à pressão do abraço do Sr. K no momento do beijo. Além disso, Dora desenvolve um medo de passar por homens que estivessem tendo uma conversa afetuosa ou animada com uma mulher. O psicanalista formula a hipótese de que Dora sentira a pressão do membro ereto do Sr. K, mas recalcou tal lembrança. Destacamos no presente trabalho, contudo, a repugnância sentida por Dora no momento do beijo do Sr. K, na medida em que esta situação se relaciona com a intensa atividade da zona erógena oral na infância de Dora, que se dá a ver na atividade de chupar o dedo.

\subsection{2}

\section{Uma pergunta acerca da feminilidade}

Lacan (1951/1998b), em Intervenção sobre a transferência, retoma a recordação de Dora de sua infância, em que ela se vê chupando o polegar e puxando o lóbulo da orelha do irmão, e, como apontamos anteriormente neste trabalho, afirma que essa cena constitui uma matriz imaginária aonde vêm se depositar as situações que Dora desenvolveu em sua vida. Além disso, o autor afirma que, através dessa cena, é possível tirar a medida do que significa a mulher e o homem para Dora. O que indica, conforme afirma o autor, que a paciente se depara com a diferença sexual.

O psicanalista francês prossegue, assinalando que "a mulher é o objeto impossível de se separar de um desejo oral primitivo, e no qual é preciso, no entanto, que ela aprenda a reconhecer sua própria natureza genital” (Lacan, 1951/1998b, p. 220). Nessa passagem, destacam-se dois aspectos importantes: a constatação de uma relação fundamental entre a oralidade e a feminilidade e a importância da função da oralidade para compreender a neurose histérica.

Percebemos que Freud (1905[1901]/2016), na descrição do caso Dora, constata um vínculo importante entre Dora e seu irmão, que se apresenta de diversas formas, como, por exemplo, no fato de Dora ter as mesmas doenças do 
irmão e no hábito de masturbação de Dora. Freud pontua que era como se Dora "tivesse sido um garoto, e somente depois se tornado uma menina" (p. 269). Percebemos, então, o estabelecimento de uma identificação masculina de Dora com o irmão, que pode ser vislumbrada na cena infantil descrita acima.

Além disso, segundo André (1998), é possível identificar nesta cena infantil uma relação "sexual" de Dora com seu irmão, que foi construída sobre um gozo de tipo oral. O autor traz algumas reflexões sobre o lugar que Dora ocupa nesta cena: seria ela a menina, gozando de sua oralidade e provocando o desejo do menino? Ou estaria ela, antes, "identificada com o menino, chupando a menina nela e perguntando o que pode ser a relação do menino a uma menina concebida como um objeto oral?” (p. 148). Com isso, afirma que, em suma, a questão da paciente poderia ser esta: "o que se torna uma mulher, se a relação de um homem a uma mulher se reduz à relação de um homem ao seio?" (p. 148).

Nesse sentido, Lacan (1951/1998b) afirma que o apelo da pulsão erótica oral, que surge sob a forma de afonia durante as ausências do $\mathrm{Sr}$. K, revela a dificuldade de Dora em estar sozinha diante da Sra. K, em uma posição de par com esta senhora. Esta análise de Lacan se difere da realizada por Freud, segundo a qual a afonia de Dora estaria relacionada ao amor recalcado pelo Sr. K. Freud também propõe que, por trás desse sintoma, estaria uma fantasia relacionada à felação, ao intercurso sexual oral entre o seu pai e a Sra. K. Lacan, por sua vez, não compartilha desta visão. Afirma, de outro modo, que a afonia de Dora tem um vínculo inconsciente com a sua vivência infantil, no sentido de serem duas situações nas quais a paciente se encontra em uma relação de par, de casal. Podemos pensar, assim, que Dora se interroga sobre o que o Outro quer dela. Essa questão nos leva a discutir como se dão as identificações para Dora, o que será tratado mais adiante.

Com isso, Lacan (1951/1998b) sublinha que o apelo de Dora à função oral, que surge nos momentos em que ela está "a dois", diz respeito a uma dificuldade de reconhecimento de sua feminilidade. E, para ela acessar o reconhecimento de sua feminilidade, tornar-se-ia necessário a realização da assunção de seu próprio corpo, "sem o que ela continua exposta ao despedaçamento funcional [...], que constitui os sintomas de conversão" (p. 220-221).

Assim, percebemos a relação entre o reconhecimento da feminilidade e a assunção do próprio corpo, que remete ao estádio do espelho descrito por Lacan 
em 1949. O estádio do espelho, desenvolvido por Lacan (1949/1998a), será abordado mais a frente para auxiliar na compreensão da assunção do próprio corpo da menina, o que está intimamente ligado à questão da identificação feminina.

Laznik (2008) traz alguns desdobramentos destas contribuições de Lacan e pontua que a imagem especular de Dora, imagem alienante, ao mesmo tempo em que fundamental como alicerce da imagem do corpo, constitui-se a partir de seu irmão, pequeno outro para Dora. Esta imagem masculina lhe servirá de eu ideal (moi), isto é, do eu na perspectiva lacaniana do eu como imagem alienante. Desde então, o eu (moi) de Dora terá uma imagem masculina, o que não significa que o ser de seu sujeito será masculino. Assim, a assunção de um corpo próprio de mulher revela-se complicado, e é neste sentido que o valor da Sra. K se apresenta. Dora, portanto, não teve acesso à sua imagem corporal feminina no estádio do espelho, o que a deixou exposta à fragmentação funcional, que pode ser identificada nos seus sintomas de conversão.

O acesso ao objeto Sra. K, contudo, só é possível através de uma identificação imaginária, seu eu (moi), imagem especular, que se institui com o Sr. K. Essa imagem vem na sucessão daquela de seu irmão, que ocorreu na primeira infância. Assim, a agressividade de Dora dirigida ao Sr. K é característica da relação narcísica com a imagem do pequeno semelhante, relação que, como foi dito, é indispensável, mas é também alienante (Laznik, 2008).

Naves (2007) assinala que, na histeria, a ênfase em determinadas zonas erógenas e na busca de uma satisfação autoerótica traduz um empenho em totalizar o corpo, a fim de que algo não seja perdido ou que escape. O papel da zona erógena oral na sintomatologia de Dora e os sintomas de masturbação infantil constituem uma busca por um gozo total, perfeito. Quando Dora sente-se excluída da relação sexual dos pais, ela regride à oralidade, na tentativa de preservar a não separação e impedir a quebra da unidade. Veremos adiante como se constitui a questão da unidade corporal para a menina. 


\subsection{3}

\section{A identificação no caso Dora}

$\mathrm{O}$ artigo Intervenção sobre a transferência, escrito por Lacan (1951/1998b), consiste em um texto chave para compreender a problemática da identificação histérica. Lacan destaca no texto de Freud sobre o caso Dora três inversões dialéticas, as quais consistem em escansões das estruturas em que, para o sujeito, a verdade se transmuta, tocando, sobretudo, na posição do sujeito. A primeira inversão dialética apontada por Lacan no texto de Freud consiste no momento em que o psicanalista diz à Dora "qual é sua própria parte na desordem de que você se queixa?” (p. 218). A segunda inversão se refere ao que Freud sublinha como a cumplicidade de Dora para proteger e permitir a relação de seu pai com a Sra. K.

O terceiro desenvolvimento da verdade que Lacan (1951/1998b) pontua diz respeito ao momento em que Freud revela o fascinado apego de Dora pela Sra.

K. A paciente de Freud dá indícios deste apego em diversos momentos, como, por exemplo, quando relatava escutar as confidências da Sra. K sobre a sua relação com o Sr. K. e, também, ao demonstrar a amabilidade que uma possuía com a outra, que denunciava um desejo mútuo em relação ao pai de Dora. Esta última chega a dizer que a Sra. K possuía um corpo de "deslumbrante brancura” (p. 219).

Freud (1905[1901]/2016) percebe que a única pessoa que Dora não rechaçava era a Sra. K, conservando uma lealdade à ela, e então o psicanalista questiona o motivo desta lealdade. Lacan (1951/1998b) afirma que essa constatação revela o real valor do objeto que é a Sra. K para Dora - o valor não de um indivíduo, "mas o de um mistério, o mistério de sua própria feminilidade, quer dizer, de sua feminilidade corporal - como se evidencia, sem nenhum véu, no segundo dos dois sonhos" (p. 220).

A percepção da importância da Sra. K para Dora explica a reação de Dora diante da declaração do Sr. K na cena do lago, que foi o momento em que a paciente adoeceu. Nessa cena, o Sr. K disse apenas algumas palavras, sendo estas “minha mulher não é nada para mim", diante do que Dora dá-lhe uma grande bofetada. Segundo Lacan (1951/1998b), essa frase desencadeia a seguinte questão para Dora: "Se ela não é nada para você, que é você para mim?” (p. 224). 
As relações entre o quarteto formado por Dora, seu pai, o Sr. K e a Sra. K mantêm-se durante anos até que a cena do lago provoca uma ruptura e Dora passa a reivindicar com exclusividade o amor de seu pai. Entretanto, pensemos antes o que era necessário para a manutenção da ambígua harmonia desses laços. Segundo Lacan (1956-1957/1995), esses laços possuíam um sentido, uma orientação perfeita: permitiam que Dora encontrasse seu lugar, mesmo que de modo instável.

Lacan (1956-1957/1995) assinala o que era essencial para essa harmonia: Dora conseguia admitir que seu pai amasse nela aquilo que estava para além dela, ou seja, a Sra. K. Para tanto, contudo, era necessário que o Sr. K ocupasse a posição inversa e equilibradora, ou seja, que Dora fosse amada por ele para além de sua mulher, na condição desta última representar algo para seu marido.

É exatamente este último aspecto que se rompe na cena do lago e eclode o drama, quando o Sr. K afirma "Você sabe que eu nada tenho com minha mulher" (Freud, 1905[1901]/2016, p. 290). O que desestabiliza Dora é a percepção de que, se a mulher do Sr. K não representa nada para ele, isso significa que ela não representa nada para o seu pai. Segundo Lacan (1956-1957/1995), nessa cena, o Sr. K “confessou não fazer parte de um circuito onde Dora poderia ou identificarse a si mesma, ou pensar que ela, Dora, fosse seu objeto para além da mulher através de quem ela se liga a ele" (p. 147).

Nesse quarteto, Dora identificava-se com o Sr. K e, por intermédio deste, é que ela se encontrava ligada à Sra. K. Esta concepção segue a mesma linha do postulado de Lacan (1956-1957/1995) segundo o qual "a histérica é alguém que ama por procuração" (p. 141). Isto significa que, na histeria, o sujeito aborda o seu objeto, um objeto homossexual por excelência, por meio de uma identificação com um indivíduo do outro sexo.

Lacan (1956-1957/1995) traz algumas pontuações a respeito da relação narcísica como fundadora do eu, Urbild da constituição dessa função imaginária que se chama moi. Assim, segundo o autor: "o eu (moi) - e somente o eu - de Dora fez uma identificação com um personagem viril, que ela é o Sr. K., e os homens são para ela outras tantas cristalizações possíveis de seu eu" (p. 141). Com isso, é mediante o Sr. K., posto que ela é o Sr. K., mais especificamente, no ponto imaginário instituído pela personalidade do Sr. K., que Dora se vincula à figura da Sra. K. 
Nesse sentido, Lacan (1956-1957/1995) aponta que a importância da Sra. K para Dora não diz respeito apenas ao fato de ela ser objeto de uma escolha dentre outros objetos; também não se relaciona com um investimento narcísico, base de todo enamoramento; mas, sobretudo, porque a Sra. K. é a questão de Dora. Os sintomas de Dora trazem consigo sua questão: o que é uma mulher? E, nesse sentido, a Sra. K encarna a função feminina e torna-se, para Dora, "a representação daquilo em que ela se projeta como sendo a questão" (p. 144).

André (1998) aponta para o mecanismo histérico de identificação que opera segundo uma bipolaridade sexual. Assim, no caso Dora, teríamos, de um lado, uma posição masculina, na qual Dora identifica-se com seu pai e com o Sr. K para contemplar a Sra. K e formular uma pergunta acerca da feminilidade da Sra. K, e, por outro lado, uma posição feminina, no sentido de que Dora se coloca na posição da Sra. K, pois ela deseja ser amada como a Sra. K é amada por seu pai e pelo Sr. K.

É nesse sentido que Lacan (1956-1957/1995) aponta que a histérica "se faz de homem", isto é, a histérica se situa em uma posição masculina, pois esta lhe oferece um lugar de onde interrogar o desejo perante uma mulher.

Essa maneira de interrogar a feminilidade, contudo, à maneira de uma identificação masculina, não resolve a questão de Dora. Percorrer a sua questão através da Sra. K. como escolha de objeto do pai não traz uma resposta para Dora, e faz relançar para esta a pergunta "O que é uma mulher?". Nesse sentido, os dois sonhos descritos no relato de Freud sobre o caso Dora ilustram como ela formula esta interrogação. Pode-se dizer que esses sonhos apontam para uma maneira masculina de interrogar sobre a feminilidade, pois esta é apreendida à maneira de um segredo interno e não como um suplemento (André, 1998).

A pergunta sobre a feminilidade a partir do desejo do pai não resolve sua questão e mantém a pergunta do desejo de Dora em aberto. A sexualidade de Dora não pode se inscrever totalmente naquilo que o pai de Dora pode dar. Pelo fato de não se inscrever totalmente em relação ao falo que permanece em aberto, como um mistério. E esse mistério se apresenta em como a questão da mulher aparece como uma imagem da qual Dora não consegue descrever sua fascinação.

Torna-se importante lembrar, contudo, que Lacan (1951/1998b) afirma que Dora conservava uma identificação com o pai, propiciada por sua impotência sexual, o que se apresentava em seus sintomas conversivos. É nesse sentido que 
André (1998) afirma que Dora não forma um par sexual com a Sra. K., pelo contrário, ao final há uma inversão identificatória: a partir do momento em que Dora demarca a posição da Sra. K. da perspectiva do homem, ela constata que desejaria ser amada por um homem e, primeiramente, por seu pai, da forma que a Sra. K. é amada por ele.

\subsection{4 \\ Os sonhos no caso Dora}

Lacan (1956-1957/1995) afirma, no seminário sobre as relações de objeto, que o primordial sobre o caso Dora concerne ao que se apresenta nos dois sonhos descritos no relato do caso. E estes sonhos indicam que a Sra. K. é a questão de Dora. Nesse sentido, é justamente porque Dora se interroga sobre o que é ser mulher, que ela se exprime através dos seus sintomas.

Sob esse fio condutor da importância dos sonhos para a compreensão da histeria de Dora, analisaremos alguns elementos importantes que se manifestam nos sonhos. Não analisaremos, contudo, a interpretação do sonho de forma minuciosa. Eis o relato do primeiro sonho na íntegra:

Uma casa está pegando fogo. Meu pai se acha diante de minha cama e me acorda. Eu me visto depressa. Mamãe ainda quer apanhar sua caixa de joias, mas papai diz: 'Não quero morrer queimado, junto com meus dois filhos, por causa de sua caixa de joias'. Corremos para baixo e, assim que estamos fora, eu acordo. (Freud, 1905[1901]/2016, p. 246)

Esse sonho se repete diversas vezes. A primeira sentença do sonho, "uma casa está pegando fogo", declarada por Dora, remete a um perigo sexual. Freud chega a tal conclusão a partir de diversos pontos trabalhados na análise de Dora. O sonho surge após a cena do lago e outras cenas na casa de L., nas quais o Sr K. faz diversas propostas amorosas para Dora, que se constituem como um perigo sexual para ela. Segundo Freud, contudo, o desejo que cria o sonho sempre advém da infância, sustentando-se concomitantemente sobre uma vivência atual e um incidente da infância. Assim, Freud admite que o sonho remonta a um perigo sexual vivenciado por Dora em sua infância. Para alcançar tal conclusão, Freud relaciona os simbolismos de água e fogo e associa a "casa pegando fogo" ao sintoma de enurese noturna de Dora. 
Este primeiro sonho tem como ponto central um termo a respeito da questão feminina: a "caixa de joias", termo que, em alemão, Schmuckkästchen, pode ser empregado para se referir ao genital feminino. Freud analisa o sonho em conjunto com atos sintomáticos de Dora durante as sessões e afirma, a partir disto, que diversos elementos remetem ao genital feminino e à masturbação infantil.

A sequência do relato do sonho aponta que a mãe de Dora procura salvar uma caixa de joias durante o incêndio, e o pai de Dora se opõe a isto. Esta cena do sonho remete a uma discussão que Dora presenciou entre seus pais por conta de uma joia. A mãe de Dora gostara de uma específica, pérolas em forma de gotas, no entanto, seu pai não gostava desta joia e a presenteou com uma pulseira. A mãe de Dora, irritada, recusa a joia e afirma que ele deveria dar de presente a uma outra. Freud aponta, contudo, que, nesta lembrança, não há o elemento "caixa de joias", e então Dora revela que havia ganhado de presente do Sr. K uma caixa de joias. A partir disso, Freud interpreta que Dora gostaria de presentear o Sr. K com sua caixa de joias, no sentido figurado. Interpretação esta que Dora não aceita.

Para André (1998), o psicanalista vienense compreende um pouco rápido demais a expressão "caixa de joias" como uma metáfora do sexo feminino. Para o autor, a caixa de joias surge nas associações de Dora como um objeto de troca entre um homem e uma mulher, ou seja, aquilo que pode ser dado ou recusado e que pode ser recusado por uma e dado à outra. Nesse sentido, as pérolas desejadas por sua mãe, relacionadas à impotência sexual do pai, trazem para Dora a questão de como a Sra. K pode ser satisfeita por um homem impotente e o que ela recebe dele.

Naves (2007) observa que Dora, diante de uma mãe com atributos marcadamente narcísicos, a que Freud se refere como tendo uma "psicose doméstica", e de um pai que se apresenta como notadamente castrado, como afirma Lacan (1991/1992 citado por Naves, 2007), permanece à deriva, isto é, fica sem ter a possibilidade de eleger mais precisamente seu objeto de amor e seu objeto de identificação, o que impossibilita que a relação pai-mãe se inscreva como uma relação homem-mulher. Além disso, para Dora, a genitalidade está vinculada a uma doença sexual, que, como denunciam seus sintomas, fica "presa na garganta", sem que seja possível digeri-la. Nesse sentido, segundo Naves (2007), "o primeiro sonho mostra o perigo vivido por Dora ao manter-se presa em 
um gozo oral e fusional com o pai, o que leva ao fracasso em representar em seu corpo a diferença dos sexos" (p. 40).

Freud ainda faz a análise de um segundo sonho de Dora. Lacan (1951/1998b) assinala que esse sonho exemplifica mais diretamente o mistério que a Sra. K representa para Dora, sendo este o mistério de sua própria feminilidade, isto é, sua feminilidade corporal. Como veremos, Freud (1905[1901]/2016) afirma que este sonho institui uma "geografia sexual simbólica" e, ao final das associações do sonho, têm-se algumas questões a respeito da sexualidade feminina. Eis o sonho descrito por Dora para Freud (1905[1901]/2016):

Estou passeando numa cidade que não conheço, vejo ruas e praças que são novas para mim. Chego à casa onde moro, subo para meu quarto e lá encontro uma carta de mamãe. Ela diz que, como eu saí de casa sem meus pais saberem, ela não queria me escrever dizendo que papai estava doente. Agora ele está morto, e, se você quiser, pode vir. Vou para a estação de trens e pergunto umas cem vezes: "Onde é a estação?". Sempre me respondem: "Cinco minutos". Então vejo um bosque cerrado à minha frente, entro nele e lá pergunto a um homem que encontro. Ele me diz: "Mais duas horas e meia". Ele se oferece para me acompanhar. Eu recuso e vou só. Vejo a estação de trens [Bahnhof] à minha frente e não posso alcançá-la. Nisso há a sensação de angústia habitual, quando não podemos seguir adiante nos sonhos. Então me acho em casa, devo ter andado de trem, mas não sei nada sobre isso. - Entro no cubículo do porteiro e lhe pergunto por nosso apartamento. A criada abre a porta e responde: "Sua mãe e os outros já estão no cemitério [Friedhof]". (p. 284-285)

O passeio em uma cidade, relatado no sonho, traz uma sobredeterminação de duas lembranças da paciente. A respeito de uma delas, Dora associa à sua primeira estadia em Dresden, onde ela vagueou pela cidade sozinha e visitou a famosa galeria, na qual permaneceu durante duas horas, admirando a pintura da Madona Sistina (Freud, 1905[1901]/2016). O tema da Madona Sistina ilustra o conflito que se apresenta no sonho. Freud observa que Dora não sabe responder o que nesta pintura lhe causa tanta admiração, apenas consegue dizer "A Madona". Esta personagem traz o tema da "mãe virgem", ou seja, de um feminino sem sexo idealizado e relacionado à maternidade.

A pergunta feita "umas cem vezes" remonta a uma pergunta feita por Dora à sua mãe na noite do sonho, a saber, "já lhe perguntei cem vezes onde está a chave” (p. 288). Sobre este ponto, Freud (1905[1901]/2016) afirma que o termo "chave" vem no lugar do termo "caixa de joias", que simboliza os genitais femininos. No mesmo sentido, diversos termos são associados ao órgão genital 
feminino: "estação de trens", em alemão Bahnhof, que se traduz literalmente como "pátio de trens"; cemitério, em alemão Friedhof, literalmente "pátio da paz"; e o termo "vestíbulo", Vorhof, literalmente "pátio anterior", que se refere a um termo anatômico atribuído à região dos genitais femininos. Além disso, as expressões "ninfas" e "bosque cerrado" contribuem para tal concepção e levam Freud a concluir que o sonho de Dora trazia uma "geografia sexual simbólica" (p. 291) e uma fantasia de defloração.

O tema da morte do pai é interpretado por Freud como um desejo de vingança. Prosseguindo a análise do sonho, Dora traz um novo fragmento do sonho: "Ela vai tranquilamente para seu quarto e se põe a ler um livro grande que está sobre a escrivaninha” (p. 292). Este livro é tido por Freud como uma enciclopédia sobre assuntos sexuais, e a morte do pai e a ida das pessoas ao cemitério possibilitaria que Dora lesse este livro "tranquilamente". Nesse sentido, têm-se novamente a interpretação da morte do pai como um desejo de vingança.

Outro fator importante deste caso são as associações a respeito de uma apendicite que acomete Dora e que provoca um sintoma peculiar, o de puxar a perna direita, sintoma este que Freud caracteriza como histérico. O autor interpreta que o desenvolvimento deste sintoma de Dora ocorre uma vez que ela, ao fazer a leitura de assuntos sexuais na enciclopédia, sente que deu um "mau passo", e passa a arrastar o pé. Quando Dora afirma que o intervalo de tempo entre este sintoma e a cena do lago era de nove meses, Freud assinala que se trata de uma fantasia de parto que remetia a um desejo infantil de gravidez, que se direcionava ao Sr. K. Diante dessa interpretação, Dora não contesta Freud, mas, na sessão seguinte, anuncia que interromperia a análise.

Nesse sentido, a resistência de Dora com relação às interpretações de Freud revelam que estas não estavam indicando a real questão de Dora. Segundo Lacan (1969-1970/1992b) observa, o modo que Dora recebe o comunicado de sua mãe "Venha se quiser" remonta ao convite da Sra. K à viagem para L., na qual ocorre a cena do lago. Esta passagem do sonho acerca da morte do pai não se refere, como afirma Freud, a uma vingança contra o pai. De acordo com Lacan, Dora encontra, no vazio de um instante deixado pelas pessoas que foram ao cemitério, um substituto do pai, ou seja, o dicionário, livro onde se ensina assuntos relacionados ao sexo. O ponto importante destacado por Lacan é o que o 
dicionário produz de saber para Dora, um saber sobre a verdade, com o qual Freud a auxilia na experiência analítica.

Podemos afirmar, assim, que Dora procura neste grande livro um saber sobre como aceder à sexualidade propriamente feminina. Lacan (1951/1998b), assim como Freud no posfácio do caso, apontam o vínculo de Dora com a Sra. K como um vínculo homossexual. André (1998), por sua vez, propõe o termo homossexuação para tratar do desejo de Dora com relação à Sra. K, referindo-se a uma homossexuação relativa aos desvios das identificações pelas quais ela precisa passar para interrogar sua feminilidade.

Assim, a questão de Dora aponta para um não saber sobre o seu lugar como desejante. Como afirma Lacan (1956-1957/1995), "Dora nada pode dizer sobre o que ela é, Dora não sabe onde se situar, nem onde está, nem para o que serve, nem para que serve o amor" (p. 149). Assim, o Sr. K consiste na metáfora de Dora. Ela sabe que há o amor e encontra nele uma historicização na qual descobre seu lugar sob o formato de uma questão. É esta questão que se manifesta nos conteúdos e articulações presentes nos sonhos de Dora. Os elementos "caixa de joias", "estação" (Bahnhof), "cemitério" (Friedhof) e "vestíbulo" (Vorhof) significam precisamente essa questão. Assim, retomamos o postulado de Lacan (1955-1956/1988) de que a questão da histérica é interrogar o que é uma mulher.

\section{4 \\ A constituição da imagem do corpo}

A noção de imagem corporal pressupõe o conceito de narcisismo cunhado por Freud em 1914. Este conceito diz respeito a um originário investimento libidinal no $\mathrm{Eu}$, estado necessário da constituição da subjetividade e regular no desenvolvimento sexual do sujeito.

Como descrevemos anteriormente, o primeiro estado da sexualidade infantil consiste no autoerotismo, segundo o qual pulsões parciais obtêm satisfação no próprio corpo. Sob esse ângulo, não há unidade análoga ao Eu no início, sendo necessário que o Eu seja desenvolvido. Para que uma passagem do autoerotismo para o narcisismo ocorra, contudo, é preciso que uma nova ação psíquica se acrescente ao autoerotismo e constitua o narcisismo (Freud, 1914/2010a). 
Sendo assim, o narcisismo se institui entre o autoerotismo e o investimento objetal. Posteriormente, uma parte do investimento libidinal no Eu é cedida aos objetos, mas permanecem relacionadas fundamentalmente. Freud indaga o porquê de a psique ter a necessidade de ir além do narcisismo e investir em objetos, formulando, então, a hipótese de que isso ocorre quando o investimento do $\mathrm{Eu}$ com libido ultrapassou uma determinada medida.

$\mathrm{O}$ autor assinala que o amor dos pais perante a criança possui papel indispensável para a constituição do narcisismo primário. Eles atribuem à criança todas as perfeições, ocultam seus defeitos e esperam que seu filho concretize os seus sonhos não realizados. Colocam o filho no lugar de "Sua Majestade, o Bebê". Com isso, a reprodução do narcisismo dos pais permite a constituição do narcisismo primário do infans. O importante aqui é ressaltar o papel fundamental da relação com o outro na formação do Eu neste princípio de unidade.

No artigo de 1914, Freud formula o conceito de Eu ideal, sendo este uma forma particular que o Eu adquire, para a qual o amor de si mesmo se dirige, amor este que foi desfrutado na infância. Assim, segundo o autor, "o narcisismo aparece deslocado para esse novo Eu ideal, que como o infantil se acha de posse de toda preciosa perfeição" (Freud, 1914/2010a, p. 40). Assim, o Eu ideal demonstra que o indivíduo não foi capaz de renunciar à satisfação que desfrutou e não quer abdicar da perfeição narcísica de sua infância.

O conceito de ideal do Eu se evidencia no artigo de Freud (1914/2010a), no momento em que este aponta para uma projeção de um ideal, ou seja, nas palavras do autor: "o que ele projeta diante de si como seu ideal é o substituto para o narcisismo perdido da infância, na qual ele era seu próprio ideal” (p. 40). Além disso, Freud pontua que o ideal do Eu surge da "influência crítica dos pais intermediada pela voz, aos quais se juntaram no curso do tempo os educadores, instrutores e, como uma hoste inumerável e indefinível, todas as demais pessoas do meio (o próximo, a opinião pública)" (p. 42).

Assim, Lacan (1957-1958/1999) distingue o Eu ideal e o ideal do Eu, designando o primeiro ao plano do imaginário e o segundo ao plano do simbólico, uma vez que este último se encontra no conjunto das exigências da lei.

Garcia-Roza (2008) ressalta que o Eu é também constituído por enunciações, juízos de valor e declarações de preferência ou de rejeição. Assim, o autor enfatiza que o Eu ideal permanece no indivíduo adulto de forma 
transformada. Não é, portanto, uma fase inicial do Eu que seria substituída pelo ideal do Eu. O ideal do Eu é descrito por Freud como algo externo ao sujeito. Trata-se de exigências que ele terá de cumprir e que se situam no âmbito da lei. Garcia-Roza (2008) retoma a passagem do texto de Freud na qual este adverte que o ideal do Eu é "imposto de fora", para sublinhar que, com esses termos, Freud aponta o caráter simbólico do ideal do $\mathrm{Eu}$, tendo esse "fora", o sentido de fora do imaginário, indicando um lugar das exigências da lei.

Segundo Kaufmann (1996), no narcisismo primário é necessário um Eu como objeto de investimento das pulsões libidinais, mas também se configura imprescindível a capacidade do sujeito de representar o que será chamado de seu Eu e que será confundida, em parte, com a representação de seu próprio corpo.

Em $O$ eu e o id (1923/2011c), Freud pontua que “o Eu é sobretudo corporal, não é apenas uma entidade superficial, mas ele mesmo a projeção de uma superfície” (p. 32). Dessa forma, o Eu deriva das sensações corporais, especialmente daquelas provenientes da superfície do corpo. O Eu representa as superfícies do aparelho psíquico e, além disso, consiste em uma projeção mental da superfície do corpo.

Em Lacan, assim como em Freud, os conceitos de Eu e de corpo estão diretamente ligados. Freud postula que é necessária uma nova ação psíquica para o surgimento do narcisismo. Para Lacan, a própria antecipação imaginária de um corpo unificado (Gestalt) surge como a matriz fundante do sujeito (Cukiert \& Priszkulnik, 2002).

Com efeito, o estádio do espelho postulado por Lacan (1949/1998a) ocorre entre os seis e 18 meses de idade, e consiste em uma primeira formação de um Eu que unifica a experiência do sujeito pela assunção de uma imagem. Lacan assinala que se trata de uma identificação em seu sentido pleno, isto é, uma transformação engendrada no sujeito, quando este assume uma imagem.

Devido à prematuridade do homem em seu nascimento, o estádio do espelho consiste em uma antecipação, na qual o sujeito se precipita "da insuficiência para a antecipação" (Lacan, 1949/1998a, p. 100). O reconhecimento da imagem especular e sua assunção são realizados com júbilo e dizem respeito à "matriz simbólica em que o [Eu] se precipita numa forma primordial" (p. 100). Essa forma primordial e totalizante do corpo só lhe é dada como Gestalt, como 
uma exterioridade, sendo esta assumida como uma miragem e situando a instância do Eu em uma linha de ficção irredutível.

Com isso, o sujeito passa da vivência de um corpo despedaçado, cuja experiência pode ser reconhecida posteriormente a partir de sonhos, para o reconhecimento de uma unidade corporal através da imagem especular. Esse momento só é possível através da mediatização do desejo do outro. Aqui, Lacan aponta para a importância do Outro na constituição da imagem corporal, sendo um momento no qual a criança busca a aprovação do Outro e este deve validar a imagem especular como sendo da criança (Lacan, 1949/1998a).

Com efeito, Fortes (2008) ressalta que, fora do estádio do espelho, a criança não possui uma imagem unificada do corpo, esta é apenas adquirida com a especularidade. Para que o Eu possa assumir o valor de sua representação imaginária, contudo, torna-se necessário que um outro reconheça a sua imagem especular como sendo sua. Portanto, é somente através da mediatização do olhar desejante do outro que a construção da imagem corporal pode ser realizada.

Em seu texto $O$ estádio do espelho como formador da função do eu, Lacan (1949/1998a) buscou ressaltar o caráter ilusório do Eu, sua virtualidade, o seu fundamento imaginário. Assim, devido ao fato de se sustentar por essa Gestalt constituinte, o Eu permanece eternamente inacessível ao sujeito. Lacan afirma ser no Eu especular a origem do drama especialmente humano de busca de identidade, drama que se repete inúmeras vezes ao longo da vida (Kaufmann, 1996).

Em um de seus seminários, Lacan (1954-1955/2010) assinala que "a regulação do imaginário depende de algo que está situado de modo transcendente [...] - o transcendente no caso não sendo aqui nada mais que a ligação simbólica entre os seres humanos" (p. 187). Desse modo, Lacan aponta que esta ligação simbólica, determinada pela lei, designa a posição do sujeito como aquele que vê. É por meio da palavra, da função simbólica, que o imaginário é ajustado. Isso se manifesta na construção do Eu ideal e do ideal do Eu do sujeito. Com isso, nas palavras de Lacan, "dessa relação a outrem depende o caráter mais ou menos satisfatório da estruturação imaginária" (p. 187).

Neste trabalho, não aprofundaremos os conceitos de Eu ideal e ideal do Eu. Gostaríamos, contudo, de destacar a ênfase dada por Lacan à dependência da identificação imaginária, isto é, à imagem corporal i(a), da identificação 
simbólica, I (A). Assim, a identidade unificada do sujeito torna-se dependente do ideal do Eu, da insígnia fundadora do Outro (André, 1998).

\section{5 \\ Imagem corporal e histeria}

Segundo Naves (2007), a clínica da histeria indica como uma das características do funcionamento histérico um empenho em alcançar a perfeição, ao mesmo tempo de uma angústia diante da possibilidade de falha ou experiência que traga proximidade com um vazio de sentido. Assim, a histérica diante do espelho busca o reflexo do Um que possa lhe assegurar a imagem de um corpo totalizado, sem cortes.

A autora prossegue afirmando que, quando a histérica se queixa de algo relacionado ao seu corpo, seja por meio de um sintoma conversivo ou não, é a função imaginária do corpo que está em jogo. Essa busca para uma totalização do corpo denuncia, a bem da verdade, uma tentativa de negar um corpo marcado por faltas e imperfeições.

Lacan (1955-1956/1988) afirma que, na histeria, trata-se sempre de uma anatomia imaginária. $\mathrm{O}$ fenômeno histérico traduz um despedaçamento anatômico enquanto fantasmático. Nesse sentido, a anatomia fantasmática possui caráter estrutural, a topografia das ramificações nervosas não recobre o que se produz com os sintomas histéricos. Os fenômenos de paralisia, anestesia, dentre outros, não são determinados pela anatomia nervosa, mas sim pela anatomia imaginária.

Para uma maior compreensão destas queixas características da clínica com a histeria, retomemos a afirmação de André (1998), segundo a qual a histérica “jamais se sente o bastante revestida por essa imagem corporal, como se essa vestimenta imaginária ameaçasse sempre se entreabrir para a realidade repulsiva de um corpo que ela não pode reconhecer como tal” (p. 109-110). Assim, o autor aponta três etapas para a problemática histérica relacionada ao corpo: primeiramente, ocorre uma falta a nível da imagem corporal i(a); essa falta, portanto, permite entrever o real do corpo dessexualizado; com isso, a simbolização histérica do sintoma (conversão ou sonho) busca reparar invadindo o imaginário. 
Como vimos anteriormente, Lacan assinala que a identificação imaginária é regulada pela identificação simbólica. Desse modo, à falta ao nível da imagem corporal deve-se corresponder uma falta à nível da identificação com o Outro. Assim, observamos a existência de uma dupla falha no processo identificatório na histeria.

André (1998), portanto, aponta como ponto de origem da neurose histérica uma falha ao nível do Outro. Nesse sentido, assinala que à falta ao nível da imagem corporal, deve-se corresponder uma falta ao nível da identificação simbólica fornecida pela instância paterna. O autor retoma o postulado de Lacan, segundo o qual a identidade unificada do sujeito depende do ideal do Eu, insígnia fundadora do Outro, que Lacan relaciona à raiz da identificação paterna. Nesse sentido, o ponto central da clínica da histeria se refere ao fato de que "o falo que a histérica encontrou em seu pai - no Pai em geral - é sempre insuficiente: o pai da histérica é estruturalmente um impotente” (p. 112) Esse ponto será retomado mais à frente.

Aqui, o questionamento da feminilidade pela histérica ganha relevo, uma vez que o pai não pode dar o apoio para a identificação feminina, a insígnia paterna só aponta o falo, a identificação fálica. Assim, é no nível do Outro que se situa a origem da desordem histérica, pois não há no Outro o significante do sexo feminino. Desse modo, segundo André (1998):

Esta falta de ponto de apoio para uma identificação especificamente feminina quer dizer, outra que não a fálica - faz com que a imagem corporal, numa mulher, não possa revestir e erotizar completamente o real do corpo - a não ser que ela se faça "toda fálica", que ela "se faça homem", o que não significa que assuma uma aparência masculina, mas que aborde a sexualidade à maneira do homem, na ostentação fálica. (p. 112)

A problemática histérica relaciona-se à convicção de possuir a resposta acerca da feminilidade e, assim, sentir-se aprisionada pela fantasia masculina. Diante da falta do Outro, a histérica vai se dedicar a repará-la, podendo chegar a sacrificar sua vida pessoal. De acordo com André (1998): “sustentáculo do pai, madona dos inválidos, a histérica se consagra a uma esperança: menos a de receber o falo do pai do que a de obter outra coisa que não o falo: um signo que funde numa feminilidade enfim reconhecida" (p. 113).

Assim, diante da falta do falo, na histeria, o corpo feminino ganhará um valor simbólico, operando, no limite, como um símbolo fálico. Isso se apresenta 
nos cuidados corporais e na busca de um "corpo perfeito" característicos da neurose histérica (André, 1998).

Deste modo, segundo André (1998), a imagem do corpo para a mulher possui uma função ambígua e problemática, que se distingue do narcisismo masculino. A imagem corporal deve paralelamente mascarar e sugerir, isto é, “deve, por um lado, recobrir o real por onde o corpo se liga ao órgão e ao objeto da fantasia masculina e, por outro lado, sugerir a presença, para além do véu, de uma feminilidade misteriosa" (p. 116).

Assim podemos pensar a neurose histérica, principalmente, a partir das noções de falicização do corpo em conjunto com a busca de uma manutenção do mistério da feminilidade. Apesar disso, existem diferentes formas de apresentação da histeria. Referenciamo-nos à busca de um corpo perfeito, mas a neurose histérica pode se manifestar a partir de, por exemplo: um corpo doente, através de repetidas queixas; por meio da negação de demandas que passam pelo corpo, como no caso de anorexia; na negação das necessidades básicas, entre outras. 


\section{Corpo histérico, feminilidade e a questão fálica}

O interesse em tratar do complexo de Édipo da menina e o desenvolvimento rumo ao tornar-se mulher está relacionado à concepção de que existem pontos de aproximação entre a feminilidade e a histeria.

Nesse sentido, podemos retomar a concepção de Lacan (1955-1956/1988), na qual ele relaciona a estrutura da neurose como partindo de uma questão, de uma relação de ser, um significante fundamental. A questão “Quem sou eu?" se refere a uma questão do sujeito, uma relação de ser. Quando esta é reanimada, contudo, como sendo simbólica, a descompensação neurótica é desencadeada, e seus sintomas, organizados. Assim, o autor afirma que, tanto a mulher, quanto o homem histérico se interrogam sobre o que é ser uma mulher.

Além disso, segundo Naves (2007), a histeria e a feminilidade possuem pontos de aproximação, mas também de oposição. Nesse sentido, Freud (1937/2018) descreve a feminilidade como um enigma e, apesar de a histeria ser referida muitas vezes como uma estrutura que impõe ao analista a premência de desmascarar o seu enigma, ela também se caracteriza por um repúdio à feminilidade.

Para a discussão deste capítulo, portanto, abordaremos a concepção freudiana da constituição da feminilidade, as contribuições de Lacan sobre essa temática, para, em seguida, tratar da problemática corporal da histérica com base nestas noções.

\section{1 \\ O complexo de Édipo nos textos iniciais de Freud}

Nos Três ensaios, como apontamos anteriormente, Freud (1905/1996m) assinala que a sexualidade infantil é caracterizada pela satisfação autoerótica, masturbatória, e organiza-se a partir de zonas erógenas. Nesse momento inicial, quando prevalece a sexualidade perverso-polimorfa, os indivíduos de ambos os sexos desconhecem a questão da diferença sexual.

Na primeira edição deste ensaio de 1905, Freud assinala duas fases de organizações pré-genitais, a fase oral e a sádico-anal, acrescentando, em 1923, 
uma terceira fase, a fase fálica, que reconhece apenas o genital masculino. A premissa fálica nos Três ensaios é o eixo de referência para os meninos e meninas, a partir da existência de uma libido de natureza essencialmente masculina e ativa. Segundo o autor, "também se poderia afirmar que a libido é, por necessidade e por regra, de natureza masculina, apareça ela no homem ou na mulher" (p. 139).

Em seções acrescentadas em 1915 ao manuscrito, Freud postula que, já na infância, há um período no qual as tendências sexuais se dirigem para uma pessoa que a criança elege, sendo a escolha objetal uma aproximação entre a vida sexual infantil e a puberdade. Apesar disso, o autor pontua que, na infância, não chega a ocorrer, ou ocorre de maneira incompleta, a subordinação à primazia dos genitais. O estabelecimento desse primado ocorreria apenas na puberdade, sendo o último estágio da organização sexual.

Em 1923, no artigo A organização genital infantil, Freud então postula a ocorrência do primado do genital na infância. A aproximação da vida sexual infantil à vida sexual do adulto vai além do advento da escolha de objeto, surgindo também um interesse nos genitais e uma atividade ligada a eles, que adquire grande significação, mesmo não ocorrendo uma verdadeira centralização das pulsões parciais sob o primado dos genitais, como na maturidade. $\mathrm{O}$ aspecto preponderante dessa organização genital infantil, que se diferencia da sexualidade adulta, diz respeito ao fato de que as crianças de ambos os sexos consideram apenas um genital, o masculino. Desse modo, segundo Freud, "não há, portanto, uma primazia genital, mas uma primazia do falo" (Freud, 1923/2011d, p. 171).

O autor assinala que o complexo de castração deve ser considerado, desde a sua origem, na fase da primazia do falo. Freud retoma experiências de danos narcísicos, tais como a perda do seio materno após a amamentação, a vivência diária de perda das fezes, e mesmo a separação do ventre materno no ato do nascimento, para diferenciá-las do complexo de castração, sendo este característico apenas da noção de perda vinculada ao genital. Neste viés, a polaridade sexual sofre mudanças ao longo do desenvolvimento sexual infantil.

Primeiramente, com a escolha do objeto, ocorre a introdução da oposição sujeito e objeto. No estágio da organização pré-genital sádico-anal, ainda não há diferenciação entre masculino e feminino, predominando a oposição ativo e passivo. Nesse sentido, no estágio da organização genital infantil, "há masculino, 
mas não feminino; a oposição é genital masculino ou castrado" (Freud, 1923/2011d, p. 175, grifos do autor). Somente na puberdade, há uma coincidência entre a polaridade sexual e as noções de masculino e feminino: o masculino reunindo a qualidade de sujeito, atividade e posse do pênis e o feminino, o objeto e a passividade.

Em 1924, o ensaio A dissolução do complexo de Édipo ressalta a importância do complexo de Édipo como um fenômeno central da sexualidade infantil, indicando novos desdobramentos para o Édipo feminino.

Anteriormente, Freud já havia apontado que a sexualidade da criança alcança uma organização, na qual o genital tem papel condutor, mas este é apenas o masculino, o genital feminino ainda não foi descoberto. A fase fálica, portanto, não se reduz apenas à convergência das pulsões sexuais no genital - a vida sexual da criança também consiste na atitude edípica perante os pais. Nesse período, Freud (1924/2011e) ainda aponta a simultaneidade da fase fálica e do complexo de Édipo para ambos os sexos. E, além disso, postula que a fase fálica não se desenvolve continuamente até a vida sexual adulta, mas submerge durante o período de latência. Assim, na infância, em função da imaturidade, o sujeito passa por um período de latência, no qual seus investimentos nos objetos serão sublimados.

Freud (1924/2011e) busca entender as causas para o abandono do complexo de Édipo, que desaparece e sucumbe ao recalque, por parte da menina e do menino. Primeiramente, o autor trata do processo que ocorre para a criança do sexo masculino, apontando diferentes possibilidades para este abandono, incluindo a hipótese de se tratar de um processo inato e destinado a ocorrer. Chega à conclusão, contudo, de que apenas o complexo de castração ocasionaria a dissolução do complexo de Édipo.

Para o menino, o complexo de castração está correlacionado à fase fálica, na qual há um direcionamento da criança para tal zona erógena. A ameaça de castração é despertada quando ocorre uma repressão por parte dos adultos quanto à manipulação do seu pênis. A constatação da possibilidade de perda de seu órgão, contudo, só ocorre quando o menino se depara com a falta de pênis nas meninas, percepção esta que desencadeia a angústia propriamente dita. Isso põe fim às duas formas de satisfação do menino no complexo de Édipo: o modelo ativo e o modelo passivo. No primeiro, ele deseja a mãe e rivaliza com o pai e, no 
segundo, ele deseja o pai e a mãe se torna supérflua. Na medida em que ambos acarretam a perda do pênis, é instaurado no menino um conflito entre um interesse narcísico, de preservar o pênis, e outro relativo aos objetos edípicos. A escolha pela preservação do pênis e do próprio Eu leva à saída do complexo de Édipo.

Além disso, Freud (1924/2011e) entende não ser mais possível equiparar o desenvolvimento sexual das meninas ao dos meninos. Aduz que os estudos feitos em relação ao desenvolvimento feminino são "obscuros e insuficientes" (p. 211). Nesse cenário, a diferença biológica entre os dois sexos apresenta relevância. Segundo Freud, "anatomia é destino" (p. 211). A menina, quando vê o genital masculino, percebe a falta deste em seu corpo, qualificando-se como inferior em relação ao menino. Primeiro, ela constrói a hipótese de que já possuiu tal membro e depois o perdeu. Depois, acredita que a perda é individual, não compreendendo que tal falta é inerente às mulheres. Para compensar tal perda, a fase edipiana das meninas se instala com o desejo de ter um filho do pai, segundo a equação simbólica pênis $=$ bebê.

Um aspecto importante é a referência à perda narcísica que ocorre no complexo de castração. Ter o falo representa a garantia de uma condição narcísica para o menino, e não reconhecê-lo nas meninas lhe traz segurança. Além disso, a falta de pênis na mulher é a origem da depreciação desta e do horror à feminilidade, revelando uma perda fundamental que determina, não apenas as posições em relação à castração, mas também a própria assunção da sexualidade (Naves, 2007).

Ainda que em 1924, Freud desenvolva algumas contribuições sobre o complexo de Édipo feminino, o autor aponta, como dito anteriormente, que estes estudos ainda são obscuros e insuficientes. Com isso, no artigo Algumas consequências psíquicas da distinção anatômica entre os sexos, Freud (1925/2011f) estabelece novas concepções relacionadas ao Édipo feminino e faz referência à ligação da menina com a mãe, ao pré-Édipo da menina, que será desdobrado posteriormente em outros textos.

André (1998) destaca que é interessante notar como o título do artigo de 1925, Algumas consequências psíquicas da diferença anatômica entre os sexos, indica a clivagem entre o psíquico e o anatômico, ou seja, que a diferença sexual anatômica não se inscreve do mesmo modo no psíquico. Neste último, é inscrito o que é consequência desta diferença, isto é, o complexo de castração. Além disso, 
como consequência desta ausência de inscrição da diferença sexual anatômica no inconsciente, têm-se dois modos distintos de pensar para a menina e para o menino: este último, ao ser confrontado com a anatomia, não sabe o que pensar dela e permanece à procura e em dúvida; por outro lado, a menina, de acordo com Freud, sabe desde o início o que se apresenta e não permanece com as mesmas ruminações que o menino.

Assim, o complexo de Édipo feminino apresenta um problema a mais que o do menino. Essa questão se relaciona ao fato de que, para ambos os sexos, a mãe consiste no primeiro objeto de amor. Nesse sentido, o menino mantém a mãe como objeto no complexo de Édipo, e a menina, por sua vez, para entrar no complexo de Édipo, deve abandoná-la e eleger o pai como objeto (Freud, 1931/2010d).

Formulando essa questão, Freud chega à problemática da pré-história da relação edípica da menina com a mãe. Assim, afirma que o Édipo da menina consiste, a bem da verdade, em uma formação secundária. Segundo o autor: "uma análise mais aprofundada desses casos, no entanto, mostra algo distinto, ou seja, que o complexo de Édipo tem aí uma longa pré-história e é, em certa medida, uma formação secundária” (p. 288).

Para a menina, o complexo de castração precede e a prepara para o complexo de Édipo. Surge um contraste primordial entre os dois sexos: o complexo de Édipo do menino sucumbe devido ao complexo de castração, ao passo que o complexo de Édipo da menina introduz-se e torna-se possível a partir do complexo de castração. A diferença consiste no fato de que, para a menina, a castração é realizada e, para o menino, esta é somente ameaçada. Freud (1925/2011f) traz um apontamento importante ao afirmar que o complexo de castração sempre atua no sentido de inibir e limitar a masculinidade e promover a feminilidade.

Nesse sentido, retomemos os aspectos descritos por Freud (1925/2011f) para definir o complexo de Édipo feminino. Na fase fálica da menina não ocorre apenas o interesse genital, a masturbação e os investimentos objetais, mas verifica-se uma descoberta repleta de consequências. A menina descobre a zona genital, isto é, nota o pênis em um menino, irmão ou companheiro, e reconhece-o como superior em contrapartida a seu próprio órgão. Eis então a inveja do pênis que se instaura na menina. 
Com isso, Freud (1925/2011f) pontua as diferenças de comportamento dos dois sexos. O menino, ao avistar a região genital da menina, mostra-se indeciso, falta-lhe interesse e ele recusa sua percepção. Apenas ao ter influência da ameaça de castração, sua recordação anterior torna-se significativa e lhe suscita diversos afetos que o levam a crer na realidade da ameaça. Essa perspectiva levará o menino a ter aversão e menosprezo às mulheres, segundo o autor.

A menina, por sua vez, rapidamente faz seu julgamento e toma uma decisão: ela vê, tem ciência de que não tem e quer ter. Desde então se instaura o complexo de masculinidade da mulher, o que acarreta diversas dificuldades para o desenvolvimento da menina rumo à feminilidade. Ela adquire a esperança de ter um pênis e de tornar-se igual ao homem ou então se manifesta uma recusa em admitir a sua castração, concomitante à convicção de possuir um pênis e realizar atitudes análogas ao homem.

Freud (1925/2011f) descreve as consequências psíquicas da inveja do pênis quando se instaura o complexo de masculinidade. A partir do reconhecimento da ferida narcísica, manifesta-se na mulher um sentimento de inferioridade, como se surgisse de uma cicatriz. Freud descreve três consequências da inveja do pênis: primeiramente, a menina acredita se tratar de um castigo pessoal; depois, ela crê na universalidade desta característica das mulheres; e, em terceiro lugar, vislumbra-se um afrouxamento da relação terna da menina com o objeto materno, o qual ela enxerga como responsável por sua falta de pênis.

Freud (1925/2011f) aponta também outro efeito da inveja do pênis: o afastamento da masturbação do clitóris, vista como uma prática masculina. Desse modo, torna-se uma necessidade, para o desenvolvimento da feminilidade, a extinção da sexualidade clitoridiana. Ocorre na menina uma revolta contra a masturbação fálica, o que se deve ao sentimento de humilhação narcísica. Assim, para que ocorra o desenvolvimento na direção da feminilidade, a libido deve passar para uma nova posição e abandonar o desejo de possuir um pênis, substituindo-o pelo desejo de ter uma criança, seguindo a equação simbólica pênis $=$ criança. 


\section{2}

\section{A feminilidade em Freud}

Será que ela é moça Será que ela é triste Será que é o contrário

Será que é pintura $O$ rosto da atriz

Se ela dança no sétimo céu Se ela acredita que é outro país

E se ela só decora o seu papel E se eu pudesse entrar na sua vida

Será que é de louça Será que é de éter Será que é loucura Será que é cenário A casa da atriz Se ela mora num arranha-céu E se as paredes são feitas de giz. E se ela chora num quarto de hotel E se eu pudesse entrar na sua vida

(Francisco Buarque de Holanda e Edu Lobo, 1983)

Um artigo publicado em 1931, Sobre a sexualidade feminina, e uma conferência realizada por Freud em 1933, A feminilidade, tratam mais especificamente da problemática da feminilidade. Ambos os trabalhos abordam, pela primeira vez de forma detalhada e extensa, o tema da feminilidade. Analisaremos os pontos importantes discorridos no artigo de 1931 e, em seguida, as contribuições feitas na conferência de 1933.

Veremos mais adiante como a compreensão de Freud acerca da feminilidade traz alguns impasses que podem ser caracterizados como um impasse histérico (Galesi, 2012). Isso ocorre uma vez que a hipótese de Freud das três saídas da menina diante do complexo de castração traz em seu bojo uma referência fálica, não tornando possível a menina se direcionar para o feminino de outro modo, a não ser através de uma ligação ao falo. Posteriormente, Lacan trará novos desdobramentos acerca do feminino. 


\subsection{1}

\section{Tornar-se mulher em Freud}

O ensaio de 1931, de título Sobre a sexualidade feminina, versa sobre alguns aspectos que haviam sido referenciados anteriormente em 1920 e 1925, desenvolvendo-os pormenorizadamente. Há um enfoque no vínculo pré-edípico da menina com a mãe, tema este que foi inicialmente abordado em 1920 no caso clínico Sobre a psicogênese de um caso de homossexualidade feminina (1920/2011a). Neste último, Freud percebe a importância do vínculo mais antigo da menina com a mãe, passando a dedicar-se à relevância da pré-história edípica, e formula a questão, que até então não havia sido apontada em seus textos: como a menina passa da relação pré-edípica para o complexo de Édipo?

Segundo André (1998), o caso da jovem homossexual é revelador, ao mostrar como a ligação com o pai não faz desaparecer verdadeiramente a relação primária com a mãe. Com base nessa ideia, o Édipo feminino passa a ser concebido como um adiamento, uma prorrogação dessa relação inicial. Freud (1920/2011a) postula, então, que a homossexualidade da menina torna-se uma contingência inscrita na estrutura do complexo de Édipo feminino, sendo um elemento de base deste, e a relação da menina com o pai passa a ser tida como uma transferência da relação primordial com a mãe. Com isso, é instituída uma dissimetria fundamental entre o menino e a menina.

Portanto, em 1931, no artigo Sobre a sexualidade feminina, Freud retoma os impasses sobre o Édipo feminino que vinham sendo problematizados em outros textos: "como acha ela o caminho até o pai? Como, quando e por que ela se desprende da mãe?" (p. 372). O autor sublinha os dois pontos importantes da sexualidade feminina: o primeiro, que se refere à transição da zona genital dominante para a vagina; e o segundo, que diz respeito à troca do objeto mãe pelo objeto pai.

Nesse sentido, há um desenvolvimento mais longo e complicado do complexo de Édipo da menina. Freud (1931/2010d) destaca dois pontos fundamentais: que o forte vínculo da menina em relação ao pai é, a bem da verdade, somente herdeiro de uma forte ligação à mãe e, nesse sentido, a mudança de objeto para o pai quase não acrescenta novo traço à vida amorosa da menina; e, em segundo lugar, o fato de que essa fase anterior de ligação com a mãe possui 
duração mais longa do que o esperado pelo autor, podendo durar até os cinco anos de idade, envolvendo de forma predominante o primeiro florescimento sexual.

Sobre a fase pré-edípica da menina, Freud (1931/2010d) afirma ter se surpreendido com essa descoberta, a qual remete, em outra área do conhecimento, à descoberta da civilização minoico-micênica detrás da grega. Afirma que as peculiaridades desse primeiro vínculo com a mãe são, para ele, "difícil de apreender analiticamente, bastante remoto, penumbroso, quase impossível de ser vivificado, como se tivesse sucumbido a uma repressão particularmente implacável” (p. 374). Apesar disso, o autor aponta que outras psicanalistas teriam tido acesso mais fácil a essa fase, sendo possível que sua dificuldade com a descoberta deste período pré-edípico tenha relação com o fenômeno da transferência em análise, da paciente com ele, um homem.

Devido à longa duração do vínculo da menina com a mãe, as fixações e repressões que posteriormente dão origem às neuroses se referem ao período de pré-edípico da menina. Freud (1931/2010d), nesse momento, questiona se a etiologia das neuroses deve ser atribuída ao complexo de Édipo, uma vez que, na menina, o pré-Édipo envolve a maior parte do período inicial da sexualidade infantil.

Em 1931, Freud versa também sobre um ponto que merece destaque no presente trabalho, a saber, que a etiologia da histeria tem relação íntima com o pré-Édipo feminino. Isso ocorre uma vez que, tanto a fase de forte vínculo com a mãe, quanto a histeria, são características da feminilidade. Apesar disso, segundo Naves (2007), ainda que esse ponto seja uma possibilidade de articulação entre histeria e feminilidade, é precisamente essa dimensão que apontará destinos distintos para cada uma.

Nesse sentido, o primeiro objeto de amor da menina, assim como o do menino, é a mãe. Ao fornecer os primeiros cuidados corporais a sua filha, a mãe acaba por erotizar seu corpo e suscitar-lhe as primeiras sensações genitais, apresentando-se como verdadeira sedutora da filha. $\mathrm{O}$ autor percebe que essa fase tem longa duração, até os 4 ou 5 anos, momento em que a menina substitui a mãe pelo pai e dá início ao Édipo positivo. Assim, Freud (1931/2010d) interroga “de que modo ocorre essa transformação, se se realiza completamente ou imperfeitamente, e que diferentes possibilidades se abrem no curso desse desenvolvimento" (p. 377). 
À mudança no sexo do objeto deve-se corresponder uma mudança no sexo da mulher. Assim, a menina deve fazer uma transição do clitóris para a vagina. A masturbação na fase fálica é realizada no clitóris, ao passo que as sensações produzidas pela vagina só aparecerão na puberdade. Sendo assim, a menina possui uma primeira fase de caráter masculino, a sexualização do clitóris, e uma fase feminina posterior, de sensações na vagina. Para Freud (1931/2010d), a menina possui duas zonas sexuais diretoras, o clitóris e a vagina, enquanto o menino possui apenas uma, o pênis. Devido a esse fato, a bissexualidade, característica da constituição humana, aparece com mais nitidez na menina do que no menino.

Pollo (2016) reitera os dois desvios próprios do destino sexual da menina observados por Freud, ou seja, a passagem pela atividade fálica e a força e a durabilidade do vínculo mãe-filha, tendo este, frequentemente, o ódio como desfecho.

Tolipan (1992) observa que, para Freud, tanto a mudança de objeto, quanto as mudanças de zona erógena, de modo de gozar e do querer feminino não são feitas por substituições, mas sim por deslocamentos. A questão aqui colocada é que o modo de relação pré-edípica perdura para a menina e, em vista disso, permanece também no destino da mulher a luta dessa "metáfora capenga" (p. 189), ou seja, a de buscar passar do registro da metonímia ao da metáfora. Desse modo, a menina permanecerá não-toda sujeitada à lei do falo, isto é, estará na lei, porém, concomitantemente, fora dela. Esse ponto será desdobrado mais a frente.

Um aspecto que diferencia o complexo de Édipo do menino e o da menina se refere ao complexo de castração. Para o menino, a descoberta da possibilidade de castração o encaminha para a dissolução do complexo de Édipo, sendo o interesse narcísico nos genitais, na preservação do pênis, o que o leva a limitar sua sexualidade infantil. Ao passo que, na menina, o complexo de castração dá início ao complexo de Édipo (Freud, 1931/2010d).

Assim, na fase fálica, a menina percebe que não possui o falo, visto aqui como uma simbolização do pênis, dando-se conta de seu "defeito". Ela admite o fato de sua castração, mas não sem se revoltar com esse estado de coisas. Diante dessa constatação, podem ocorrer três orientações de desenvolvimento: a primeira a leva a um afastamento ou cessação da atividade sexual de um modo geral; na segunda, a menina desenvolve o que se chamou de "complexo de masculinidade", no qual ela se apega à masculinidade ameaçada, se prende à esperança de, em 
algum momento, adquirir o pênis e, em determinados períodos, fantasia ser um homem; a terceira consiste na orientação ideal e constitui o caminho para a feminilidade definitiva, na qual a menina escolhe o pai como objeto de amor. Desse modo, escreve Freud (1931/2010d):

Na mulher, portanto, o complexo de Édipo é o resultado final de um longo desenvolvimento; não é destruído, mas sim criado por influência da castração, escapa às fortes influências hostis que no homem atuam de forma destruidora sobre ele e, de fato, com muita frequência não é superado pela mulher. (p. 379)

Segundo Silva e Folberg (2008), na primeira saída, há, sobretudo, uma atitude de desvalorização da menina em relação à mãe, quando ela atesta a falta de pênis na mãe, o que a impele a abandonar a atividade masturbatória e recalcar a maior parte de suas inclinações sexuais, uma vez que seu clitóris perde valor ao ser impossibilitado de ser ostentado como objeto fálico, do modo que é feito pelo menino com relação ao seu pênis.

A segunda saída, o complexo de masculinidade, consiste em uma recusa da menina em constatar a falta de pênis materno e, por conseguinte, sua própria falta, acentuando sua masculinidade prévia, atendo-se à atividade clitoridiana e recolhendo-se em uma identificação com a mãe fálica ou com o pai, mantendo-se na esperança de vir a ter um pênis, constituindo uma relação íntima com a inveja do pênis. As consequências dessa saída são o sentimento de inferioridade, um modo singular de ciúme feminino, uma distância com relação à mãe enquanto objeto, e uma forte oposição contra a masturbação clitoridiana.

A terceira saída se refere ao caminho que conduz à feminilidade. Nesta, a mulher deve ser capaz de operar um deslizamento simbólico, abandonando o objeto materno e se direcionando ao pai, diante do qual ela deve endereçar seu desejo por um filho como representante de um desejo feminino por excelência (Silva \& Folberg, 2008).

O complexo de masculinidade consiste em um tema caro para a psicanálise, portanto, abordaremos algumas questões inerentes a este processo que contribuem para a discussão do tornar-se mulher. Tolipan (1992) aponta alguns impasses que se desdobram a partir do "complexo de masculinidade". Segundo a autora, este último possui, resumidamente, duas consequências principais para a menina: ter um filho como forma de recompensa, ou, ao rejeitar a falta, 
comportar-se como um homem. Nesse sentido, Freud acaba por apontar o caminho para a feminilidade como ser mãe ou ser "como um homem".

Segundo Silva \& Folberg (2008), o complexo de masculinidade não aparece somente sob as influências e peculiaridades das experiências pré-edípicas, mas também surge associado à imagem que a menina conservará de seu próprio corpo, que está alicerçado na relação inicial com a mãe. Primeiramente, a mãe se refere tanto ao outro (pequeno outro) quanto ao Outro (grande Outro) da menina. Em outras palavras, o pequeno outro da amamentação é, ao mesmo tempo, o primeiro grande Outro que transmite os valores, gostos, a apropriação do corpo, e através do qual chega à filha o pai da sua lei. São duas mães que coexistem em uma só, portadoras da mensagem, pois o pai chega à menina através da mãe. Como resultado, o sujeito que permanece fixado nesse momento da constituição subjetiva se torna vítima de um abismo significativo entre o que aparece como uma impotência e uma impossibilidade. Não sabe ou não pode saber do fato de que a relação sexual não existe e, desse modo, sente-se sempre em defasagem, do mesmo modo que a mulher descrita por Freud em 1923, que possui inveja do pênis e complexo de inferioridade.

Segundo observa Salgado (2008), nas três saídas da menina frente ao impasse da castração existe a presença da questão fálica: na primeira, a inibição sexual ou a neurose, na segunda, o complexo de masculinidade, e, na terceira, a feminilidade "normal" pela maternidade. Desse modo, pode-se entrever que o psicanalista vienense relaciona intimamente a feminilidade e o impasse da castração a uma submissão à ordem fálica. Essa problemática será retomada por Lacan, que buscará desdobrar os caminhos para a feminilidade a partir de uma perspectiva que não a coloque como uma submissão à ordem fálica.

Kehl (1998) aborda esse assunto de forma semelhante. A autora também argumenta que essa oposição radical entre o homem fálico e a mulher castrada não se sustenta na própria teoria psicanalítica freudiana. Freud descreve a mulher como castrada, porém estabelece que, para a mulher conquistar o homem, ela não pode se colocar apenas na posição de objeto, dado que ele almeja o falo. Portanto, Freud caracteriza a sedução feminina como fálica - as mulheres transformam seu corpo em objeto fálico e, dessa forma, pressupõem ter o que o homem quer. Além disso, ainda de acordo com a concepção de Freud, as mulheres também almejam o falo. A saída do Édipo só se dá quando a menina tem o pai como objeto de amor e 
busca obter, por meio da maternidade, um filho, que simboliza o falo. Aqui, "a feminilidade é um truque, e a posição feminina um sacrifício temporário oferecido pela mulher freudiana ao homem em troca de um único interesse verdadeiro: o filho-falo" (p. 244).

Sob esse aspecto da feminilidade, Joan Riviere (1929/2005), em texto intitulado A feminilidade como máscara, se pergunta se existe diferença entre a feminilidade genuína e a feminilidade como uma máscara e arremata que não existe tal diferença. Nesse sentido, tal caráter nas mulheres possui uma dupla função: por um lado, encobrir a fantasia de posse do pênis do pai e, por outro, proteger do perigo de retaliação dos pais. Diante dos homens, a mulher buscaria se disfarçar como castrada e se colocaria na posição de humildade, devoção e admiração destes. E, de outra parte, os homens buscariam entender tal mistério, devido à existência dessa máscara, desse disfarce. A autora dá exemplos de situações cotidianas em que mulheres inteligentes e competentes, ao se verem diante de uma conversa com homens, mudam de postura e ocultam todo seu conhecimento.

Dando continuidade ao texto freudiano de 1931, Freud postula que o complexo de Édipo na menina possui um problema a mais, devido à necessidade de abandonar o objeto materno. Esse trabalho nunca se realiza inteiramente, uma vez que, frequentemente, na vida adulta, a mulher escolhe o marido a partir do modelo do pai, entretanto, repete com ele a relação complicada com a mãe. Assim, a relação original da menina foi com a mãe e "sobre ela construiu-se a ligação ao pai [...]. O traslado das ligações afetivas do objeto materno para o paterno constituiu o teor principal do desenvolvimento que leva à feminilidade" (Freud, 1931/2010d, p. 380). Nesse sentido, ocorre uma espécie de transferência do relacionamento materno para o relacionamento com o pai.

Diante disso, Freud (1931/2010d) busca compreender os mecanismos que atuam para o afastamento da menina deste vínculo tão intenso com o objeto materno. Primeiramente, aponta características da sexualidade infantil que levam à frustração e contribuem para o fim desta ligação. São elas: o ciúme de outras pessoas, rivais ou mesmo o pai, sendo que o amor desmedido da criança requer exclusividade, e o fato de o amor infantil não possuir meta e ser incapaz de atingir satisfação, fica destinado a acabar em decepção. É somente o complexo de castração, contudo, que leva ao afastamento em relação à mãe. Assim, o motivo 
principal para este afastamento se refere às recriminações que a menina possui diante da mãe, que não a proveu de um genital verdadeiro.

A menina frequentemente possui falas de recriminação, carregadas de ressentimento com relação à mãe. Freud (1931/2010d) observa que diversas queixas não passam de um descontentamento geral da criança, como, por exemplo, a queixa de que a mãe não a amamentou por tempo suficiente, reclamações em relação ao amor da mãe que é dividido com outras pessoas, a ambivalência que é uma característica geral da sexualidade infantil, sendo experimentada pela criança na forte ligação que possui com a mãe. Freud revela, contudo, que esses motivos são insuficientes, uma vez que tais atributos da sexualidade infantil também são vividos pelo garoto que, apesar disso, permanece com a escolha de objeto inicial. Portanto, deve haver um motivo específico para a menina abandonar a mãe e se voltar para o pai, sendo este seu ressentimento em relação à mãe que não a dotou do órgão masculino.

Além disso, as noções de passividade e atividade são utilizadas pelo autor para uma maior compreensão da fase de ligação da menina com a mãe. A partir desse referencial, observa-se que as metas sexuais da menina são de caráter ativo e passivo, e influenciadas pelas fases da libido que ela atravessa, podendo revelar tendências orais, sádicas e fálicas dirigidas à mãe. As primeiras vivências sexuais da criança com a mãe são de natureza passiva, por exemplo, ela é amamentada, nutrida, limpada. Uma parte da libido se satisfaz com essas situações, mas outra parte busca convertê-las em atividade. A predileção das meninas pela brincadeira de boneca é um exemplo de situação na qual a menina busca dominar ativamente os cuidados maternos que viveu de forma passiva. Nesse momento, as brincadeiras de boneca revelam uma identificação à mãe e se dão em uma relação de exclusividade com ela, em concomitância com uma negligência do objeto-pai.

Desse modo, desejos agressivos orais e sádicos aparecem como medo da menina de ser morta pela mãe, o que, na verdade, encobre o desejo de matar a mãe. Na fase fálica, a menina tem seu corpo erotizado pela mãe, o que dá sensações de prazer. Posteriormente, contudo, a menina acusa a mãe da sedução. Com a transição para o pai, o papel de sedutor sexual também é transferido para este.

Torna-se importante destacar novamente que o afastamento em relação à mãe consiste em um passo significativo, que vai além de uma simples mudança de 
objeto. Simultaneamente, ocorre uma diminuição dos impulsos sexuais ativos e um reforço daqueles passivos. Assim, a menina deve cessar a masturbação clitoridiana e recalcar sua masculinidade anterior para ser conduzida pelas vias da feminilidade e, com o traslado para o pai, entrar no complexo de Édipo (Freud, 1931/2010d).

A respeito dessa dialética, Freud (1931/2010d) aponta que a psicanálise concebe a existência de apenas uma libido, que dispõe de metas e formas de satisfação ativas e passivas. Torna-se interessante destacar a afirmação do autor que indica que, nessa oposição e, principalmente, na existência de metas passivas, "está contido o restante do problema" (p. 393). Assim, tomando este postulado em conjunto com a concepção descrita anteriormente de que a feminilidade coincide com o aumento de metas passivas, podemos refletir sobre a compreensão psicanalítica da feminilidade e este ponto onde "está contido o problema", ou seja, a oposição ativo e passivo e, principalmente, as metas passivas. Em 1933, Freud vai dizer que o complexo de masculinidade, uma das três orientações para a menina frente à castração, se refere a uma necessidade de evitar a onda de passividade necessária para o desenvolvimento da feminilidade. Nesse sentido, podemos destacar a existência de uma problemática do sujeito relativa à passividade e nos indagar como essa questão se apresenta para a menina com relação à feminilidade.

Observamos que, ao longo de sua obra, Freud mantém aberta a questão sobre o desejo feminino, que foi substancialmente expressa na pergunta endereçada à princesa Marie Bonaparte “O que quer a mulher, afinal?” (Bertin, 1989, p. 250). Entretanto, em 1937, no artigo Análise terminável e interminável, ao deparar-se com os entraves do trabalho analítico, Freud localizou o impasse no que denominou de "rejeição da feminilidade [...], uma parte do grande enigma da sexualidade" (p. 325).

Nessa linha, Galesi (2012) aponta que os dois limites do pensamento freudiano revelados em 1937, a saber, as problemáticas da sexualidade feminina e da figura do pai, são dois pontos que acabaram por enclausurar a posição feminina em um impasse histérico. 


\section{2 .2 \\ Desdobramentos do feminino em Freud: a proposta de investigar como a mulher vem a ser}

A conferência A feminilidade de 1933 contém a ilustre frase de Freud, a qual referencia que o papel da psicanálise não deve ser o de estudar e descrever a mulher, mas sim buscar compreender como a mulher vem a ser. Refere-se aqui ao fato de o percurso da menina para se tornar uma mulher possuir caráter mais longo e complexo que o do menino. Nas palavras de Freud,

É próprio da peculiaridade da psicanálise, então, que ela não se ponha a descrever o que é a mulher - uma tarefa quase impossível para ela -, mas investigue como a mulher vem a ser, como se desenvolve a partir da criança inatamente bissexual. (Freud, 1933/2010c, p. 269)

Desse modo, Freud (1933/2010c) volta a tratar da especificidade do complexo de Édipo feminino. O autor enfatiza o papel da poderosa ligação da menina em relação à mãe, e destaca a particularidade da menina, cujo complexo de castração prepara o Édipo, no lugar de destruí-lo, como ocorre no menino. A inveja do pênis leva a menina a se afastar do objeto materno e entrar no complexo de Édipo "como num porto seguro" (p. 286). Essa particularidade de ausência do medo da castração consiste em um ponto complicador para a menina, que permanece sem o motivo essencial que leva o menino a superar o complexo de Édipo.

A feminilidade (1933/2010c) retoma a ideia de que cabe à menina abandonar o objeto materno para ir em direção ao objeto paterno. Nesse sentido, o autor destaca a hostilidade que se apresenta ao final da relação com a mãe, ou seja, segundo o autor, "o afastamento em relação à mãe ocorre sob o signo da hostilidade, a ligação materna acaba em ódio. Um ódio assim pode se tornar conspícuo, e durar por toda a vida” (p. 275). Assim como em 1931, Freud lista novamente em 1933 uma série de motivos colocados pela menina para fundamentar suas queixas e acusações contra a mãe e justificar o sentimento de hostilidade para com esta. O autor afirma, contudo, que estes fatores também aparecem na relação do menino com a mãe, e não o conduzem à separação do objeto materno. Assim, o fator específico para a menina se desvincular da mãe e eleger o pai como objeto é o complexo de castração, ela "responsabiliza a mãe por sua falta de pênis e não lhe perdoa essa desvantagem" (p. 279). 
Freud (1933/2010c) aponta que a identificação da menina com a mãe adquire duas camadas, "a pré-edípica, que repousa na ligação afetuosa com a mãe e a toma por modelo, e a posterior, vinda do complexo de Édipo, que busca eliminar a mãe e substituí-la junto ao pai” (p. 292). Nesse sentido, muitos aspectos das duas identificações persistem para a menina, não sendo nenhuma das duas propriamente superadas no decorrer do desenvolvimento. Contudo, a fase decisiva consiste naquela de ligação pré-edípica, uma vez que, nela, a mulher adquire os atributos com os quais ela exercerá seu papel na função sexual e cumprirá as suas ocupações sociais. No vínculo inicial com a mãe, a menina também adquire a inclinação afetuosa para o homem, convertendo em paixão a ligação edípica com a mãe. Freud aponta que o amor do homem e o da mulher devem estar separados por uma distinção de fases psicológicas.

André (1998) observa que o texto freudiano deixa a impressão de um afastamento irreparável entre o amor do homem e o da mulher, e afirma que se torna importante constatar que a conclusão da elaboração freudiana sobre a feminilidade consiste em um impasse, mais especificamente, um duplo impasse, o do tornar-se mulher e, também, o do casal, em que o tornar-se mãe torna preponderante a relação mãe-filho no lugar da relação mulher-marido.

Nesse sentido, o fim da ligação com a mãe ocorre com o complexo de castração. Naves (2007) sublinha que, para Freud, a questão da feminilidade se refere principalmente à dimensão da castração e do desejo. À medida que Freud escreve sobre esse tema, contudo, ele revela também diversos impasses para abordá-lo teoricamente. Com isso, a autora observa que esses impasses podem indicar outra via para a compreensão da feminilidade, que vai além do falo e do Édipo.

Podemos perceber esses impasses quando Freud (1933/2010c) se propõe a abordar a questão da feminilidade madura, estudando as características da mulher. Freud assinala que existe uma relação entre a feminilidade e o narcisismo que interfere na escolha de objeto da mulher, a qual tem mais necessidade de ser amada do que de amar. Segundo Freud (1933/2010c), essa característica feminina advém da inveja do pênis, pois a mulher usa de seus encantos e de sua vaidade física para compensar sua inferioridade. A respeito do pudor, Freud coloca que, ao mesmo tempo em que este consiste em uma característica feminina por excelência, possui a intenção original de encobrir os genitais considerados 
defeituosos, e, por outro lado, assinala que este atributo é muito mais convencional do que se imagina, tratando-se de um atributo construído por uma convenção social.

Além disso, Freud (1933/2010c) aduz que as mulheres possuem pouca noção de justiça, e que isso advém do predomínio da inveja na vida psíquica destas. Também é característico da feminilidade pouco interesse social e uma menor capacidade de sublimação do que a dos homens, assim como, a existência de uma diferença no posicionamento das mulheres e dos homens frente à análise. Enquanto os homens demonstraram interesse em explorar os efeitos da análise, as mulheres possuíam maior fixidez, que, por sua vez, alcançava um ponto sem avanço. Isso porque "sua libido tomou posições definitivas, e parece incapaz de abandoná-las por outras" (p. 293). Dessa forma, "não há trilhas para mais desenvolvimento; é como se todo o processo já tivesse decorrido, permanecendo ininfluenciável a partir de então; de fato é como se a difícil evolução até a feminilidade tivesse esgotado as possibilidades da pessoa" (p. 293).

Após tratar do aspecto enigmático da feminilidade, que ocasiona dificuldade na compreensão das mulheres, Freud conclui que a psicanálise não possui aparato teórico para solucionar esse enigma. $\mathrm{O}$ autor afirma que o estudo da psicanálise sobre a feminilidade é "certamente incompleto e fragmentário, e nem sempre parece amigável” (p. 293), e também assinala que, "se quiserem saber mais sobre a feminilidade, interroguem suas próprias vivências, ou dirijam-se aos escritores, ou esperem até que a ciência possa lhes dar informação mais profunda e coerente" (p. 293).

Ademais, Freud (1933/2010c) traz dois pontos interessantes a respeito das mulheres, que serviram de base para importantes contribuições de outros autores a respeito da feminilidade. O psicanalista vienense assinala neste artigo que é próprio da feminilidade um vínculo com a vida pulsional: "há um nexo particularmente constante entre feminilidade e instintos, que não pretendemos ignorar" (p. 268). Outro ponto importante é o que Freud sublinha como particular da feminilidade, a saber, uma relação com o tecer e o trançar, conforme escrito por ele: "talvez elas tenham inventado uma técnica, a de tecer e de trançar" (p. 290). Esses pontos serão retomados mais a frente, a fim de auxiliar a compreensão do feminino à luz da psicanálise lacaniana. 
Sob esse ângulo de pensar os impasses de Freud sobre a feminilidade, no sentido de indicar uma outra via além do falo e do Édipo, retomemos a problemática do pré-Édipo feminino, sobretudo o fato de que a ligação com a mãe perdura e mantém sua força mesmo depois que a menina toma o pai como objeto. André (1998), a respeito disso, destaca um ponto importante: “o pai não se impõe verdadeiramente como metáfora no destino feminino, ou, mais exatamente, a filha é não toda assujeitada a essa função de metáfora" (p. 181). Assim, o autor afirma que há um fracasso, ao menos parcial, da metáfora paterna no caso da menina, isto é, ao menos, se deve colocar em questão a metáfora que se instala pela instância paterna. Em outras palavras, a significação introduzida pela metáfora paterna permanece incompleta para conceder a um sujeito seu lugar de mulher.

Posteriormente, esta questão será trabalhada por Lacan (1958/1998e), isto é, o fato de o pai ser sempre insuficiente para significar à filha a questão da feminilidade. Isso ocorre uma vez que a função do pai é a introdução do sujeito na lei do falo, na representação simbólica. Nesse sentido, deve-se retomar a concepção de Freud, segundo a qual a menina, frente à ameaça de castração, deve, por um lado, renunciar à masturbação clitoridiana, e assim desviar-se de seu falicismo, e, por outro lado, trocar de objeto para entrar na fase edípica. A menina, portanto, deve abandonar o objeto inicial materno, passando a odiá-lo ao fim desse processo.

$\mathrm{O}$ aspecto que traz um embaraço intrínseco para a menina é que, apesar da hostilidade direcionada à mãe, a menina deve mantê-la como objeto de identificação. Nesse sentido, instala-se para a menina uma situação paradoxal, na qual ela permanece entre a questão de ser objeto de desejo da mãe e tomar a mãe como objeto de identificação (Naves, 2007).

Assim, podemos perceber a questão que se coloca para a menina, a saber, que se constitui para ela um processo identificatório em duas vertentes: uma que se baseia no vínculo pré-edípico com a mãe, em que ela tem a mãe como primeiro objeto de amor; e outra marcada pelo complexo de Édipo, na qual ela deve tomar a mãe como rival, para que ela possa ocupar um lugar junto ao pai (Silva \& Folberg, 2008).

Em 1933, Freud aponta que a identificação da menina com a mãe adquire duas camadas: "a pré-edípica, que repousa na ligação afetuosa com a mãe e a toma por modelo, e a posterior, vinda do complexo de Édipo, que busca eliminar a 
mãe e substituí-la junto ao pai” (p. 292). O autor sublinha que muitos aspectos das duas identificações persistem para a menina, não sendo nenhuma das duas propriamente superadas no decorrer do desenvolvimento. A fase decisiva, contudo, consiste naquela da ligação pré-edípica, uma vez que, nela, a mulher adquire os atributos com os quais exercerá seu papel na função sexual e cumprirá suas ocupações sociais. No vínculo inicial com a mãe, a menina também adquire a inclinação afetuosa para o homem, convertendo em paixão a ligação edípica com a mãe. Freud (1933/2010c) aponta que o amor do homem e o da mulher deve estar separado por uma distinção de fases psicológicas. Podemos refletir se essa constatação de Freud revela os germes do que será desdobrado posteriormente por Lacan (1958/1998e) e que pode ser circunscrito pelo aforismo "não há relação sexual" (p. 454).

\section{3 \\ A devastação e a questão histérica}

Em 1958, no artigo A significação do falo, Lacan faz a primeira menção à noção de devastação. Este termo diz respeito à relação mãe e filha, relação esta que, na maior parte dos casos, se constitui de maneira devastadora. Assim, Lacan vai dizer que a devastação ocorre uma vez que a menina espera mais substância da mãe do que de seu pai. Nas palavras de Lacan (1958/1998e),

a elucubração freudiana do complexo de Édipo, que faz da mulher peixe na água, pela castração ser nela ponto de partida (Freud dixit), contrasta dolorosamente com a realidade de devastação que constitui, na mulher, em sua maioria, a relação com a mãe, de quem, como mulher, ela realmente parece esperar mais substância que do pai - o que não combina com ele ser segundo, nessa devastação. (p. 465)

Zalcberg (2012) afirma que a relação devastadora que pode existir entre mãe e filha fala da expectativa da filha de receber uma identificação feminina da mãe, exatamente no ponto em que se coloca a impossibilidade de uma transmissão da feminilidade.

Segundo Zalcberg (2012), a noção de devastação foi empregada por Lacan em dois momentos de seu ensino. Assim, em 1958, conforme afirmamos acima, Lacan traz o aspecto devastador da relação da menina com a mãe, sendo esta o primeiro objeto de amor da menina. Ao passo que, em 1975, Lacan traz a noção de devastação para se referir à relação da mulher com um homem, ou seja, "este 
que é para ela uma aflição pior que um sintoma, a saber, uma devastação" (19751976/2007 citado por Zalcberg, 2012, p. 469). Nesse sentido, a devastação tratase, para uma mulher, do retorno da demanda de amor.

Ao destacarmos estes dois pontos característicos da devastação, afirmamos, contudo, que vamos dar um enfoque maior à relação da menina com a mãe, a fim de poder refletir sobre a problemática da transmissão da feminilidade e, então, abordar os impasses na histeria.

Essa dificuldade na relação da menina com a mãe havia sido apontada por Freud (1931/2010d), ao afirmar que a transição da escolha de objeto do pai permite que a menina escape à "catástrofe". Assim sendo, o vínculo com a mãe pode gerar obstáculos na constituição da feminilidade. Essa questão se entrelaça com a dificuldade da menina de separar-se da mãe e tomar o pai como objeto e, também, devido à complexidade do encontro com o pai, pois a ausência de falo na menina instaura uma falta, a qual o pai não pode recobrir inteiramente.

Como vimos, esse movimento da menina, de separação da mãe em direção ao pai, traz dificuldades identificatórias para a menina. Assim, Naves (2007) sublinha que o percurso para tornar-se um sujeito feminino apenas será realizado se a menina for capaz de, ao separar-se da mãe, conservar traços identificatórios desta última, que a conduzirão ao pai. Nesse sentido, à medida que ela conseguir se posicionar neste lugar de identificação perante a mãe, para além do ódio sentido no momento da separação, a menina será capaz de trocar de objeto e desejar não mais a mãe, mas o objeto de desejo desta, o pai. De outra parte, o encontro com o pai também revela uma problemática identificatória, dado que, como afirmamos, este não pode recobrir por inteiro a falta da menina caracterizada pela ausência de falo. Com isso, a menina será sempre confrontada com a carência de representação, uma vez que, por um lado, a mãe, por ser mulher, não pôde concedê-la e, de outro, o pai se revela parcialmente como uma referência simbólica, visto que o vínculo com a mãe não é abandonado inteiramente, não ocorrendo uma completa substituição metafórica por parte do pai.

Nesse sentido, Naves (2007) observa que a noção lacaniana de devastação diz respeito ao forte vínculo da menina com a mãe, que é determinado pelo prejuízo provocado pelo fato de a mãe não lhe fornecer um significante capaz de identificá-la como sujeito feminino. Possivelmente, o ódio sentido pela menina 
perante a mãe advém deste fato. À medida que a menina constata que a mãe é estruturalmente impossibilitada de evitar que ela se depare com a ausência, não do pênis, porém de um significante que lhe ofereça uma referência identificatória, ela se ressente. E é precisamente esse ressentimento que a auxilia a separar-se da mãe e direcionar-se ao pai, ainda que não de todo. Assim, Lacan (2001/2003 citado por Naves, 2007) escreve que o apelo ao pai como aquele capaz de dar à menina o falo não surge em um primeiro momento na constituição da feminilidade, mas surge em segundo lugar, como resposta à devastação que é vivenciada entre a menina e a mãe.

Apesar das dificuldades encontradas pela menina em seu percurso, apenas ao encarar esta devastação tornará possível que ela constate impreterivelmente a impossibilidade de uma fusão entre ela e a mãe, do impossível de um prolongamento entre ambas. Apenas assim será possível que ela renuncie a uma reivindicação fálica e se oriente em direção a um gozo propriamente feminino. Saindo assim do lugar de objeto da mãe, em direção ao caminho que lhe assegura o acesso à posição de sujeito feminino (Naves, 2007).

Segundo Zalcberg (2012), o desdobramento do gozo feminino diz respeito à concepção de que a mulher não está toda sob a regência do complexo de Édipo, do mesmo modo que o homem está. Este mais além do Édipo característico da mulher institui que ela não se submeta inteiramente à castração nem tampouco à lógica fálica. Lacan (1972-1973/2008b), contudo, sublinha que a mulher está referida à função fálica, ainda que não esteja inteiramente sob a sua regência. É nesse sentido que Lacan se refere à "loucura" feminina, mas afirmando que se as mulheres são loucas, elas são não todas-loucas ou não loucas de todo.

Com isso, torna-se importante destacar o que alguns autores apontam, a saber, que o fim da elaboração realizada por Freud acerca da feminilidade conduz a um impasse. André (1998) questiona se, de algum modo, Freud pode ter tido a necessidade de conservar o feminino como uma figura de esfinge para poder sustentar seu desejo de decifrar. Em diversos momentos, Freud apontou para o lado misterioso, irracional e até mesmo perigoso da feminilidade e, por outro lado, a conservou em seu estatuto de enigma e obscuridade. Assim, conclui que o desejo de Freud pode se assemelhar ao de Dora, que se colocava como adoradora, subjugadora e ávida de saber com relação ao corpo da Sra. K. Por outro lado, é 
importante ressaltar que se pode questionar se existe outro desejo que não o histérico.

A partir disso, deve-se refletir sobre a possibilidade de interrogar as verdades da doutrina psicanalítica. Lacan propõe realizar uma releitura de Freud e afirma que a teoria da castração consiste em um meio-dizer, que possui certa função. André (1998) traz uma importante reflexão e questiona se, no limite, a teoria da castração e o primado do falo não podem levar a que se situe e proteja a feminilidade como um mistério, sendo a teoria de certo modo máscara e reveladora do objeto que busca conhecer.

\title{
4.4 \\ Histeria e relação com o corpo a partir do debate sobre o falo em Lacan
}

\author{
Não sabemos como era a cabeça, que falta, \\ de pupilas amadurecidas. Porém \\ o torso arde ainda como um candelabro e tem, \\ só que meio apagada, a luz do olhar, que salta \\ e brilha. Se não fosse assim, a curva rara \\ do peito não deslumbraria, nem achar \\ caminho poderia um sorriso e baixar \\ da anca suave ao centro onde o sexo se alteara. \\ Não fosse assim, seria essa estátua uma mera \\ pedra, um desfigurado mármore, e nem já \\ resplandecera mais como pele de fera. \\ Seus limites não transporia desmedida \\ como uma estrela; pois ali ponto não há \\ que não te mire. Força é mudares de vida.
}

(Rainer Maria Rilke, 1926/1966)

O percurso teórico freudiano a respeito da feminilidade, não obstante sua irrefutável importância, trouxe diferentes impasses, a que nos referimos acima. Podemos observar esta questão em outros dois exemplos, quando o autor afirma que a vida sexual da mulher adulta consiste em um continente negro (1926/2014) para a psicologia, e que a psicanálise não possui aparato teórico para solucionar o enigma da feminilidade (1933/2010c), este conceito tornou-se de difícil apreensão para Freud. 
Ainda que tenha partido do arcabouço teórico de Freud, Lacan formula uma teoria própria, trazendo contribuições importantes aos conceitos freudianos. Com isso, buscaremos introduzir alguns pontos relevantes de sua concepção da feminilidade e, para isso, partiremos de sua abordagem do complexo de Édipo.

Para Lacan (1957-1958/1999), o complexo de Édipo se institui em três tempos, segundo os quais a relação do sujeito com o falo é princeps e passa por modulações. Veremos a seguir como esses três tempos e a dialética do falo operam.

No primeiro tempo do Édipo, a questão que se coloca é ser ou não ser o falo, no plano imaginário, o que se dá da seguinte maneira: a criança procura, como desejo de desejo, satisfazer o desejo da mãe, ou seja, ser ou não ser o falo, o objeto de desejo da mãe. Nesse sentido, a criança procura se tornar o que supõe ser o objeto satisfatório para a mãe. Além disso, começa a ter sensações em seu órgão genital e passa a mostrá-lo para sua genitora, com a ideia de saber se é mesmo capaz de algo. Trata-se da etapa fálica primitiva e, neste momento, a primazia do falo está instaurada no mundo através da existência do símbolo, do discurso e da lei, e é desse modo que a metáfora paterna age. A criança, contudo, sente somente o resultado disso e, para ela, é suficiente ser o falo da mãe. Nesta etapa, "o sujeito se identifica especularmente com aquilo que é objeto do desejo de sua mãe" (Lacan, 1957-1958/1999, p. 197).

Valdivia (1997) comenta que este momento se refere ao falo que se encontra na ordem da cultura, tal qual um pano de fundo. O desejo da mãe se orienta através dele e a criança é submetida aos caprichos de sua genitora, sendo o seu desejo o desejo desta última. Aqui, trata-se da mãe fálica, e a criança é o seu falo, de tal modo que a criança já se encontra no desejo do Outro, de sua mãe.

No segundo tempo do Édipo, o pai intervém como privador da mãe. Nesse momento, chega para a criança a lei do pai, um primeiro aparecimento da lei que indica que a mãe é dependente de um objeto, que vai além de um objeto de seu desejo, sendo um objeto que o Outro tem ou não tem. Trata-se da dialética de ter ou não ter o falo, e é necessário que seja instaurado que não se pode tê-lo, de modo que a possibilidade de ser castrado torna-se fundamental na assunção da possibilidade de ter o falo (Lacan, 1957-1958/1999).

O caráter determinante desta etapa deve ser relacionado à relação da mãe não com o pai, mas com a palavra do pai. E, para que a lei opere, torna-se 
fundamental que ela seja veiculada ao discurso da mãe, que instaura o pai no lugar daquele que lhe faz a lei.

Saggese (2001) destaca que, neste momento, se verifica uma operação fundamentalmente simbólica, tratando-se aqui do pai simbólico, isto é, um termo ordenador que indica uma lei que rege o desejo da mãe. Este termo surge através de uma construção metafórica, a fim de registrar no simbólico o que a mãe pode desejar, aquilo que tem um nome, um significante. Assim, reitera que "o nome vai aparecer pelo movimento da metáfora, que é o da substituição significante, como Nome-do-Pai, representante da incógnita do desejo materno" (p. 35).

É nesse tempo que o pai intervém como portador de uma proibição com relação às primeiras manifestações do instinto sexual. A criança começa a destacar e exibir seu instrumento, oferecendo-o à mãe, e ela responde mostrando ao filho o quanto é insuficiente o que este lhe oferece, sendo, assim, colocada em prática a proibição do uso do novo instrumento. Nesse ponto, a função do pai - o Nome-do-Pai - está relacionada à proibição do incesto, um obstáculo entre o filho e a mãe, sendo, desse modo, o portador da lei. Além disso, é neste tempo que se constituem as estruturas neurótica, psicótica ou perversa (Lacan, 19571958/1999).

Silva \& Rey (2011) apontam que, neste segundo tempo, o pai intervém como privador da mãe de forma dupla, ou seja, priva a criança do seu objeto de desejo e, além disso, priva a mãe de seu objeto fálico. Sendo assim, como dito anteriormente, o pai vai surgir mediado pelo discurso materno.

No terceiro tempo, por sua vez, deve ser mantido o que foi prometido pelo pai no segundo tempo. Neste último, o pai atestou ser portador ou suporte da lei, dependendo dele a posse do falo pela mãe. No terceiro tempo, o pai pode dar ou recusar, à medida que o tem, tendo, contudo, que dar provas de que o tem. $\mathrm{O}$ importante aqui é que o pai intervém como aquele que tem o falo, e não como aquele que o é. Nesse sentido, pode-se produzir a báscula que reinstaura o falo como objeto desejado da mãe, distinguindo-se de um objeto do qual o pai pode privar. Segundo Lacan (1957-1958/1999), “o pai pode dar à mãe o que ela deseja, e pode dar porque o possui. Aqui intervém, portanto, a existência da potência no sentido genital da palavra - digamos que o pai é um pai potente” (p. 200). Este é o tempo da saída do complexo de Édipo, que ocorre após a privação e a castração da mãe nos dois primeiros tempos. 
Neste tempo, passa-se a ter a identificação com a instância paterna como ideal do Eu, incidindo o declínio do complexo de Édipo pela identificação do menino com o pai como possuidor do pênis e da menina pelo reconhecimento do homem como aquele que o possui.

Em 1958, Lacan aponta dois pontos importantes a respeito do complexo de castração, sendo este um primeiro papel que instala no sujeito uma posição inconsciente em que ele possa se identificar com seu sexo. Ele afirma que o complexo de castração possui uma função de nó e aponta duas vertentes desta função, a saber: na estruturação dinâmica dos sintomas, isto é, no que estes são analisáveis nas neuroses, perversões e psicoses; e, em segundo lugar, na regulação do desenvolvimento que confere a esse papel inicial sua ratio, ou seja, aquilo que instaura no sujeito uma posição inconsciente. Esse ponto, estando ausente, impossibilitaria que o sujeito se identificasse com o modelo ideal de seu sexo, ou ainda, o impossibilitaria de responder, sem incidentes consideráveis, às necessidades de seu par na relação sexual, ou as necessidades da criança procriada a partir daí.

Com o objetivo de elucidar o falo no aparato teórico de Freud, Lacan (1958/1998e) sublinha que a relação do sujeito com o falo ocorre sem levar em conta a diferença anatômica entre os sexos e, por conta disso, possui interpretação complexa na mulher e em relação à mulher. Assim, Lacan retoma as últimas elaborações clínicas de Freud, a respeito do desenvolvimento sexual da mulher, e distingue quatro tópicos: a) a menina se considera castrada, ainda que por um instante, e, em relação à privação do falo, ela atribui essa ocorrência à mãe e, em seguida, ao pai, além disso, nessa transição deve-se admitir uma transferência, no sentido analítico do termo; b) ambos os sexos consideram a princípio a mãe como provida do falo, como mãe fálica; c) a significação da castração resulta da descoberta da castração da mãe, e somente a partir disso atinge-se a formação de sintomas; d) esses três pontos levam à fase fálica, que possui os aspectos de predominância imaginária do atributo fálico e do gozo masturbatório da criança.

Desse modo, Lacan (1958/1998e) se propõe a esclarecer as noções de fase fálica e, mais especificamente, de falo, cunhadas por Freud. O psicanalista francês se baseia e parte de dois aspectos que Freud destaca como fundamentais na análise: o repúdio da feminilidade nos homens e a Penisneid nas mulheres. Assim, busca esclarecer a concepção freudiana de que só é possível o “desenvolvimento 
psíquico ideal", ou identificação aos ideais de cada sexo, com a presença do falo. Com isso, Lacan afirma que é através do mito característico do complexo de Édipo que é possível certificar o irredutível da castração. Ele aponta que a estrutura de mito auxilia na compreensão da estrutura do complexo e na formação dos sintomas (Pollo, 2016).

Nesse sentido, sublinha que, na abordagem freudiana, o falo não é uma fantasia, no sentido de um efeito imaginário, sequer trata-se de um objeto, que geralmente indica a realidade que se implica em uma relação, e, tampouco, se refere ao órgão, pênis ou clitóris, que ele simboliza. Afirma então que o falo é um significante que se refere a um denominador comum dos outros significantes: "ele é o significante destinado a designar, em seu conjunto, os efeitos de significado, na medida em que o significante os condiciona por sua presença de significante” (Lacan, 1958/1998e, p. 697).

Além disso, o psicanalista francês afirma que o falo só pode realizar seu papel enquanto velado, ou seja, como signo da latência pela qual é constituído tudo o que é significável, à medida que é alçado à função de significante. Segundo o autor, "o falo é o significante dessa própria Aufhebung [suspensão] que ele inaugura (inicia) por seu desaparecimento" (Lacan, 1958/1998e, p. 699). Lacan aponta também que o "falo como significante dá a razão do desejo" (p. 700). Assim, a partir do desaparecimento do falo é que se inaugura o desejo. Através da ameaça ou nostalgia da falta-a ter o significante fálico é a marca do desejo e, nesse sentido, para ambos os sexos, tem como efeito projetar as manifestações ideais ou típicas de cada comportamento até o que se constitui como um limite, o ato da copulação, que Lacan caracteriza como comédia. Portanto, há uma “intervenção de um parecer que substitui o ter, para, de um lado, protegê-lo e, de outro, mascarar sua falta no outro" (Lacan, 1958/1998e, p. 701). Lacan afirma que essas relações terão como ponto central a questão de um ser e de um ter. Assim, a mulher, para ser o falo, ou seja, o significante do desejo do Outro, irá rejeitar uma parcela fundamental da feminilidade, mais precisamente todos os seus atributos na mascarada. Ela busca ser desejada pelo que ela não é e, ao mesmo tempo, visa ser amada.

Pollo (2016) reitera a diferença descrita por Lacan do mecanismo que se opera na Verwerfung (foraclusão), a partir do qual ressurge no real o que não se faz simbólico, e o que se opera através do significante falo, ou seja, que permite 
que reapareça no simbólico o que se perdeu como objeto real. Nesse sentido, a castração humaniza ou edipianiza a sexualidade perverso-polimorfa. À medida que se faz o luto do falo, há o primeiro aparecimento do desejo, que corresponde à dissolução do Édipo e também à renúncia ao narcisismo primário.

Lacan (1958-1959/2002) afirma, a respeito do que se torna sujeito à medida que este é simbolicamente castrado, que o sujeito "foi simbolicamente castrado ao nível de sua posição como sujeito falante, não de seu ser, desse ser que tem que fazer o luto dessa alguma coisa que ele deve oferecer em sacrifício, em holocausto, a sua função de significante faltante" (p. 370).

Assim, Pollo (2016) reitera que, a partir da fala, ocorre a eclipse do sujeito como real. O falo surge apenas por seu reflexo nos objetos, concedendo-lhe um brilho agalmático. No entanto, quando há um desaparecimento do objeto, em um instante, surge seu correspondente no sujeito, o falo. Nesse sentido, segundo o autor, "à perda do objeto corresponde, literalmente, a falicidade, paradoxal felicidade que é falicidade subjetiva" (p. 84). Estas concepções nos auxiliam a compreender como o falo sexualiza o corpo, porém, a partir do seu reflexo nos objetos que se dá com base na ausência do objeto, de sua perda, não já a partir de sua presença. Lacan busca ilustrar esta concepção, tomando uma das falas ditas por Hamlet "the body is with the King but the king is not with the body", a qual traduz, fazendo algumas modificações: “o corpo está com o Falo, mas o Falo não está com o corpo" (Lacan citado por Pollo, 2016).

Segundo Costa e Ferreira (2019), o falo subjetiva o corpo como um corpo sexuado e, assim sendo, limitado, destituído de satisfação plena. Isso ocorre em razão do Pai, que instaura a ordem, designa limites e negativiza o gozo. O nomedo-pai institui a castração do Outro e, por conseguinte, a castração do próprio sujeito. Através do registro do nome-do-pai no corpo, o sujeito se limita ao gozo fálico, isto é, ao gozo sexual.

Essa aceitação do gozo fálico direciona o sujeito para a castração, tornando-se a perda fundamental para a existência do corpo, e, nesse sentido, o gozo ocasiona sempre uma ausência, um vazio, uma vez que há a incorporação simbólica da falta, consecutiva da inserção do sujeito na cultura. Essa ausência, que se manifesta para o sujeito como algo inominável, Lacan denominou de maisde-gozar, isto é, “o mais de gozar é a função da renúncia ao gozo sob efeito do 
discurso" (Costa \& Ferreira, 2019). Apesar da referência ao conceito lacaniano de mais-de-gozar, este não será aprofundado no presente trabalho.

Em outras palavras, o falo é o significante que assinala a falta e, nesse sentido, simboliza o desejo. Por tratar-se do significante da falta, o falo encobre o furo no Outro, mas não inteiramente, tendo, portanto, um jogo de presença e ausência. Esta falta é constituída pela linguagem e, diante disso, no corpo biológico, nada falta, ao passo que, no corpo falante, que está inscrito na linguagem, tudo falta (Costa \& Ferreira, 2019).

Ao longo do ensino de Lacan, a noção de falo ganha novas dimensões. Lacan (1960-1961/1992a) vai apontar o falo como o significante que "representa alguma coisa para alguém" (p. 258), mas não só, o significante não faz somente signo para alguém, faz "signo de alguém” (p. 258). Assim, Pollo (2016) reitera o postulado de Lacan, segundo o qual o falo é o significante que "pode se tornar idêntico ao sujeito, e é por isso que o sujeito é inconsciente" (Lacan, 19601961/1992 citado por Pollo, 2016, p. 85).

Outras definições a respeito do falo ganham contorno a partir da dialética dos dois gozos que Lacan dá início em 1960 (citado por André, 1998) e que ganhará o seu desdobramento no seminário Mais, Ainda (1972-1973/2008b). Nesse sentido, segundo Lacan (1960 citado por André, 1998), o significante do falo inaugura uma divisão do gozo e assume uma dupla função: de um lado, proíbe o gozo, e, de outro, o permite. A partir dessa concepção, o primado do falo pressupõe a impossibilidade da relação entre ambos os sexos, de um "ser macho" a um "ser fêmea", só sendo possível a relação a partir do registro do semblante.

Com isso, o significante do falo impossibilita que se possa tratar, no ser humano, de um instinto sexual, ou seja, a ideia de uma atração automática de todo homem por toda mulher e vice-versa. Eis a inovação trazida por Freud, a de que a falta de tal instinto possibilita que a sexualidade humana tenha uma relevância inusitada. Em outras palavras, em oposição à unificação da noção de sexualidade, há uma disseminação de uma série de pulsões parciais, sendo nenhuma delas, por essência, genital (André, 1998). 


\subsection{1 \\ O corpo histérico e a questão fálica}

A partir da discussão sobre o falo descrita acima, propomos uma reflexão sobre a problemática da histeria.

Retomaremos um dos primeiros escritos de Freud sobre esse tema, a saber, o artigo Observações adicionais sobre as neuropsicoses de defesa (1896/1996), no qual ele descreve a seguinte equação: recalcado = sexual (representações sexuais). Podemos observar que, já nesse momento inicial, e a respeito da neurose histérica, Freud percebe que o processo significante do recalque aponta para um processo de sexualização do real. Em outras palavras, Freud inscreve o real em uma linha de significação, a qual, com o avanço de seus trabalhos, vai desembocar na noção de significação fálica (André, 1998).

Abordamos este ponto mais profundamente no primeiro capítulo e, no tópico anterior, observamos como essa sexualização que se opera a partir do recalque vai ser desenvolvida, ao longo da obra de Freud, na noção de significação fálica. A partir destas teorizações, podemos refletir sobre a problemática do Édipo feminino, segundo a qual há uma questão estrutural na constituição da mulher, uma vez que esta não encontra no pai o apoio necessário para assentar sua identidade feminina. Posto isso, a histeria constrói uma demanda ao pai, que põe em causa essa falta radical, ou seja, o fato de encontrar em seu pai o falo, sempre insuficiente, um pai estruturalmente impotente.

De acordo com André (1998), a demanda da histérica ao pai, que aponta para uma falta inteiramente radical, traz em seu bojo algo a mais do que um fracasso do recalque, traz efetivamente uma impossibilidade de recalcar. Para o autor, esta problemática advém do fato do representante que deveria ser recalcado estar ausente, $\mathrm{d}$ o fato de não haver no Outro o significante do sexo feminino.

Esta questão se entrelaça com a problemática corporal na histeria. André (1998) aponta que a falta de ponto de apoio para uma identificação especificamente feminina, ou seja, outra que não a fálica, tem como consequência que a imagem corporal da mulher não possa revestir e erotizar inteiramente o real do corpo. A saída que a histérica encontra é fazer-se "toda fálica", que ela "se faça de homem”. Por outro lado, isso não significa que a histérica vá adquirir uma 
aparência masculina, em vez disso, ela aborda a sexualidade à maneira do homem, através de uma ostentação fálica.

Em outras palavras, a mulher histérica se faz de homem, se faz "toda fálica" e, com isso, o seu lado feminino é abandonado. No entanto, adiante da questão "qual é este real onde fica abandonada a parte propriamente feminina da feminilidade?” (p. 112), a histérica possui a convicção de possuir uma resposta e, assim, sente-se aprisionada pela fantasia masculina. Diante da ausência de um signo identificatório fálico, a histérica "tem um corpo feminino", no sentido de que este corpo adquire um valor simbólico como símbolo fálico (André, 1998).

Como vimos, Lacan (1958/1998e) aponta que as relações entre os sexos se refere à dialética de ser ou ter o falo. Nesse sentido, ao nível simbólico, os homens inclinam-se a ter o falo e as mulheres a sê-lo. Ao nível imaginário, contudo, ocorre o que Lacan denominou de intervenção de um parecer e, então, ambos os sexos realizam o papel de parecer deter o falo: quando ele o tem, para protegê-lo, e quando ela não o tem, para ocultar sua falta. Desse modo, ocorre o que abordamos mais acima, a saber, a mulher, na busca de ser o falo, o significante do desejo do Outro, vai rejeitar uma parte fundamental da feminilidade na mascarada. Assim, "é pelo que ela não é que ela pretende ser desejada, ao mesmo tempo que amada" (André, 1998, p. 701).

Nesse sentido, André (1998) pontua que a mulher, mais do que desejar possuir o falo do mesmo modo que o homem, busca se servir dele com o intuito de ser desejada. O autor observa então que, se a mulher "representa a comédia do falo, não é tanto porque ela o deseje possuir da mesma forma que o homem, mas antes porque se serve dele para lançar sua isca" (p. 701).

Segundo Lacan (1957-1958/1999), a histérica, por sua vez, fica às voltas com a questão de ser ou não ser o falo. Como mulher, a histérica se faz máscara a fim de, por trás da máscara, ser o falo. Eis, então, a posição da mulher na histeria: "se é preciso que o que não se é seja o que se é, resta ser o que se é e empurrar o que se é para o parecer"' (p. 392).

Além disso, Lacan (1957-1958/1999) afirma, a partir da referência a um caso clínico, que todo o comportamento da histérica manifesta-se no gesto, feito pela paciente, da mão levada ao botão, acompanhado pela frase "Não vale a pena", uma vez que o falo não será encontrado ali. Assim, Lacan retoma uma noção de Freud, segundo a qual, na histeria, há uma prevalência do ver e do saber. 
Assim, o psicanalista francês aponta como a passagem para a dimensão do significante sempre comporta algo de mortificado. Isso se apresenta sob a forma do véu e, na histeria, observa-se esse fenômeno a partir de seu corpo, do "corpete da histérica" (Lacan, 1957-1958/1999, p. 396). Essa é a posição da mulher com relação ao desejo, trata-se da noção de que por trás da combinação "não vá procurar ver", porque não há nada, exceto o significante. Na mulher, o véu encobre quase a totalidade do seu ser. Lacan aponta que a problemática de desvelamento do falo está entrelaçada com a questão do pudor, sendo que o desvelamento que não mostra nada, que só mostra uma ausência, é sentido pela mulher com horror. Essa questão está relacionada com o sexo feminino e a ideia de horror que a este está relacionada.

Assim, André (1998) afirma que o narcisismo feminino se relaciona a essa noção, segundo a qual a mulher busca suspender uma ponta da máscara, de tal forma que o mistério, e não o órgão, possa aparentar se revelar. Aqui, há uma identificação a um semblante que possui um risco, uma vez que o sujeito-mulher que se direciona para este caminho pode apenas ter esta imagem, mantendo-se sempre à distância, de forma separada da máscara que cria sobre a cena do mundo e, além disso, não possui nada a nível do Outro que lhe dê um ponto de referência. Assim, segundo André (1998),

Identificação imaginaria do corpo feminino é para uma mulher uma formação fundamentalmente frágil e precária sempre ameaçada de se romper numa hiância e sempre experimentada como algo surgido de um artificio, - falsa identidade, um substituto. (p. 116)

A histérica visa denunciar esta ausência de uma identidade feminina, a falta no Outro de um significante do sexo feminino e a falha que procede daí ao nível da identificação especular. Isso advém do fato de o pai ser insuficiente por definição e a histérica possuir uma lógica que busca um "mais que o falo", portanto, há uma fantasia histérica com relação à precariedade da identificação feminina. André (1998) afirma: “a histérica teme que sob essa máscara da falicização da imagem do corpo só haja 'isso', quer dizer, o real orgânico ao qual se reduz o corpo dessexualizado. Em resposta, ela produz um excesso de sexualização do corpo imaginário" (p. 117).

Lacan (1955-1956/1988) afirma que a realização do sexo da mulher no complexo de Édipo possui um desvio suplementar, uma vez que deve passar pela 
identificação com o objeto paterno. Essa desvantagem da mulher, no que tange ao acesso a sua identidade, que diz respeito ao seu próprio sexo e à sexualização, torna-se uma vantagem no caso da histeria, uma vez que, neste caso, há uma identificação imaginária com o pai, que lhe é acessível graças a sua posição na composição do Édipo. Na histeria, portanto, é constituída uma posição masculina, o que aponta para uma dificuldade de caráter sexual.

A questão “O que é ser uma mulher?”, feita pela histérica, relaciona-se com o corpo feminino. Lacan (1955-1956/1988) traz esse ponto no Seminário 3, afirmando que a fantasia de um corpo despedaçado e a fantasia inconsciente de gravidez são características da histeria.

Costa e Ferreira (2019) destacam que a histérica atua por se perguntar o que é ser mulher. Essa atuação pode se tornar teatral ou excessiva, e tem a função de fazer semblante do que considera ser uma mulher. Não possuindo o suporte fálico, a histérica faliciza seu próprio corpo, ou seja, não possuindo o falo, ela se torna o falo. A histérica atua para o Outro e, assim, seu corpo todo, identificado ao falo, faz-se de falo para o olhar do Outro.

A histérica se reveste de adereços, joias, gestos e vestes, sugerindo, através da mascarada, que há algo a mais ali, que não pode ser visto, um segredo a se revelar. Com isso, há um apontamento para um lugar além da aparência, da máscara, que não pode ser alcançado (Costa \& Ferreira, 2019).

Diante dessas questões, a histérica busca encontrar a feminilidade em outra mulher. Lacan (1957/1998d) afirma que é através de um sujeito de seu próprio sexo, nesse para-além, que a histérica é capaz de invocar o que pode lhe dar corpo, uma vez que não foi possível saber como ganhar corpo aquém dele. Isso ocorre devido à ausência de resposta desse outro, e ela permanece diante de um substituto do outro imaginário, não em alienação, mas em suspenso. Nesse sentido, a histérica "experimenta a si mesma nas homenagens dirigidas a uma outra, e oferece a mulher, em quem adora seu próprio mistério ao homem cujo papel ela assume, sem dele poder usufruir" (p. 453).

Nasio (1991) afirma que a conversão histérica consiste em um fenômeno de falicização do corpo não-genital e, ao mesmo tempo, de retirada do interesse do corpo genital. $\mathrm{O}$ autor aponta que, tanto na histeria feminina quanto na masculina, o histérico permanece petrificado na fantasia de castração. Sente-se uma angústia de perder o que julga ser o essencial de si, seu falo, e perde-se na questão de saber 
se é homem ou mulher. É em torno do universo fálico que se encontra a angústia do sujeito histérico. O grau de indeterminação da identidade sexual do sujeito histérico determina o quanto ele se apega ao seu falo, ampliando assim sua angústia, que se manifesta em sintoma e sofrimento.

Sabe-se desde Freud, contudo, que na histeria há um duplo movimento: por um lado, encontra-se uma excitação que abala o corpo de forma global e, por outro, uma inibição que influencia a região genital estritamente. Nasio (1991) assinala que isso ocorre uma vez que, ao nível inconsciente, há uma redução do corpo para ser apenas o falo, ao passo que o corpo real do histérico é invadido pelo fenômeno da falicização. Desse modo, "o corpo real torna-se um corpo que sofre por ser um imenso falo" (p. 57-58)

Com isso, a zona genital permanece esvaziada e desinvestida e o corpo não-genital é excitado e organizado como um falo potente, que assume um lugar de adoração narcísica, objeto de seduções, embora também fonte de intensos sofrimentos. Assim, o corpo histérico torna-se o falo e o histérico compreende que ter o falo é, na verdade, sê-lo (Nasio, 1991).

Nesse sentido, Nasio (1991) afirma que, como o objeto que falta para a histérica é o falo, ela produz esse excesso de narcisismo, esse falicismo difundido na totalidade de seu corpo. E, assim, ao mesmo tempo em que esse narcisismo lhe traz um sentimento de existir, têm-se o preço do sofrimento e sensação de estar sendo submetida às solicitações do mundo externo.

O importante é destacar o caráter da histérica de um corpo-falo afetado por um excesso de narcisismo, em consonância com uma genitalidade zero. Com isso, sua sexualidade é vivida pela totalidade de seu corpo, com exceção do local onde deveria vivê-la. Há uma abstenção do gozo da penetração e da sexualidade genital (Nasio, 1991).

Torna-se importante destacar que Lacan vai introduzir um novo modelo com a noção de gozo, que designa que uma parte da sexualidade humana responde à castração, a partir das insígnias identificatórias, ao passo que outra parte não responde a essa lógica. Trata-se de um gozo suplementar ao gozo sexual e, assim, não se vincularia a um órgão, situando a posição feminina para além da função paterna, não totalmente inscrita no Nome-do-Pai, e, assim, esse gozo jamais seria completamente simbolizável (Silva \& Santos, 2017). 
Não aprofundaremos este postulado da fórmula da sexuação cunhado por Lacan, apenas apontaremos que, a partir dessa noção, podemos pensar, de acordo com André (1998), como a imagem corporal na mulher se constitui como algo problemático. Nesse sentido, do lado da mulher, o sujeito é "não-todo" representado pela função do falo, assim, a mascarada feminina possui o estatuto de uma máscara designada a fazer ex-sistir como mistério um ser feminino hipotético, um mistério referido à lógica do signo, como algo insignificável. Nesse sentido, a imagem do corpo possui uma função problemática para a mulher, uma vez que esta deve, ao mesmo tempo, recobrir o real por onde o corpo se vincula ao órgão e ao objeto da fantasia masculina, e indicar a presença, para além do véu, de uma feminilidade misteriosa.

Por fim, no caso da histeria, percebe-se uma contradição em seu interior, que lhe causa sofrimento. A histérica busca positivar a feminilidade e denunciar o semblante da máscara fálica. Ela padece, contudo, do fato de que, com esse movimento, ela consegue alguma coisa, mas não justamente o que ela queria. Ao tirar a máscara, ela deixa de obter a função pela qual ela aparentava possuir uma enigmática presença feminina e se depara, na verdade, com o real assexuado do corpo - nos termos lacanianos, com o objeto a, tornando imprescindível o recurso à máscara novamente (André, 1998).

Podemos perceber que esse movimento gera, para a histérica, um aprisionamento. Apesar de seu intuito de positivar a feminilidade, ela ainda está sob a lógica fálica, o que a conduz a um aprisionamento, não podendo se ver fora desta lógica, a qual ela busca denunciar e se deslocar. 


\section{5 Considerações finais}

Propusemo-nos, nesta dissertação, pensar sobre a estrutura clínica da histeria e sua relação com o corpo, pontuando os aspectos fundamentais do entrelaçamento entre este quadro clínico e a corporeidade. Consideramos como essencial o fato de que a presença do corpo não se apresenta apenas na formação de sintomas, sendo presente na origem da constituição da neurose e, mais fundamentalmente, considerando o pressuposto de que não há sujeito, não há inconsciente, sem corpo.

Assim, primeiramente, a partir dos textos iniciais da teoria freudiana, abordamos principalmente dois eixos para uma compreensão da neurose histérica: um que considera o conflito entre representações incompatíveis e outro que aborda o excedente, a excitação, a intensidade, que se referem à noção de traumático. Paralelamente a isso, observamos dois vieses de compreensão dos sintomas histéricos: um que se refere aos sintomas de conversão, paralisias e ataques histéricos que apontam para uma determinação simbólica, realização de uma sexualidade autoerótica e substituição de uma fantasia inconsciente; e, por outro lado, sintomas de susto, repulsa e lacunas de discurso que apontam para uma queda do erótico, que têm como consequência irromper a função orgânica do corpo, repugnando a histérica. Consideramos que estes primeiros escritos trazem pontos preciosos para a compreensão de fenômenos corporais da histeria.

Assim, no capítulo seguinte, utilizamo-nos dos conceitos de sexualidade perverso-polimorfa, identificação e narcisismo, a fim de desdobrar a importância da pulsão sexual na neurose histérica, o caráter oral dos sintomas corporais de Dora, a questão identificatória da mesma e a problemática relacionada à imagem corporal da histeria.

No último capítulo, trouxemos um enfoque na temática da feminilidade, uma vez que existem pontos de encontro entre o feminino e a neurose histérica, sendo esta última constituída com base na pergunta “O que é uma mulher?". Além disso, o corpo, enquanto marcado pelo sexual e pelo falo, foi investigado a fim de compreender como se estrutura a imagem corporal da mulher quando esta não possui o suporte fálico para assentar sua identidade feminina. Diante disso, vimos 
que a histérica possui a convicção de possuir uma resposta, e acaba permanecendo aprisionada na fantasia masculina, uma vez que, não tendo o falo, ela busca sê-lo, identificando seu corpo todo ao falo.

Percebemos assim que a histeria, apesar de denunciar a máscara fálica e buscar positivar a feminilidade, constitui-se em uma posição geradora de sofrimento, uma vez que esta reivindicação fálica gera sintomas corporais que buscam obstruir qualquer possível falta ou imperfeição. Há uma dificuldade da histérica com a feminilidade (Naves, 2007).

Com isso, partindo do sonho da injeção de Irma, observamos o confronto de Freud com esse algo de inominável que surge na imagem aterradora da garganta de Irma. Esse avesso da carne, esse algo de inominável e irrepresentável é o que atesta a histérica por meio de sintomas como repulsa, lacuna no discurso e susto. A partir do caso Dora, percebemos que esse inominável aparece na figura da Sra. K., de quem a jovem possui um fascínio que não consegue descrever ou nomear. No terceiro capítulo, por sua vez, observamos que, para nomear esse vazio, a histérica necessita de um saber fálico e tem a convicção de que é o pai que detém esse saber e pode nomear este algo de inominável.

Sendo assim, podemos retomar a epígrafe escolhida para a dissertação. Sabemos que a música “Ain't got no - I got life” de Nina Simone pode ser lida a partir de diferentes aportes teóricos, sobretudo, pelo ativismo político da artista e pelo contexto no qual foi escrita, de movimento pelos direitos civis dos negros nos Estados Unidos. Contudo, propusemo-nos fazer uma leitura com base nos eixos teóricos da psicanálise discutidos na dissertação, ou seja, o feminino, a corporeidade e a histeria. Observamos na letra a descrição de como o eu lírico aborda esse negativo que habita todo sujeito, do que não se é. Ela não tem nada, contudo, ela tem alguma coisa da qual pode dizer, ela tem seus traços, seus ideais, que vão cercando o que ela é, mas que não são propriedades dela.

A guisa de conclusão, a presente pesquisa buscou circunscrever os postulados freudianos e lacanianos a respeito da estrutura clínica da histeria e os fenômenos corporais desta, a fim de permitir um aprimoramento da escuta desses casos na clínica. Consideramos que a riqueza das referências teóricas sobre a histeria contribui para o desenvolvimento de uma escuta mais sensível e fundada a partir dos pilares da psicanálise. 
Como afirmamos anteriormente, a estrutura da histeria permanece até os dias atuais, fazendo-se presente na clínica. Os sintomas, contudo, já não são os mesmos daqueles que se evidenciavam no período de Freud. Assim, por fim, perguntamo-nos: de que modo os sintomas corporais se apresentam atualmente na clínica? Alguns estudiosos deste tema apontam para novas formas de expressão sintomática da histeria atualmente. Portanto, testemunhamos hoje como os sintomas histéricos ou, conforme nos diz Lacan, os "envelopes formais" que se manifestam na clínica hoje, possuem o corpo como território de expressão. $\mathrm{Na}$ presente dissertação, nosso foco se guiou para entender a circunscrição da histeria, tendo como referência Freud e Lacan. Visualizar os modos e as roupagens que a histeria tem na clínica contemporânea pode ser uma temática a ser desenvolvida posteriormente. 


\section{6 \\ Referências bibliográficas}

André, S. (1998). O que quer uma mulher? Rio de Janeiro: Jorge Zahar.

Alonso, S. L. \& Fuks, M. P. (2012). Histeria. São Paulo: Casa do Psicólogo.

Bertin, C. (1989). A última Bonaparte. Rio de Janeiro: Paz e Terra.

Bassols, M. (2016). O Inconsciente, feminino, e a ciência. Lacan 21, 1. Recuperado de http://www.lacan21.com/sitio/2016/04/16/o-inconscientefeminino-e-a-ciencia/?lang=pt-br

Breuer, J. \& Freud, S. (1996). Estudos sobre a Histeria (1893-1895)(Edição standard das obras psicológicas completas de Sigmund Freud, v. 2). Rio de Janeiro: Imago. (Trabalho original publicado entre 1893 e 1895).

Bursztyn, D. C. (2008). O tratamento da histeria nas instituições psiquiátricas: um desafio para a psicanálise. Estudos e Pesquisas em Psicologia, 8(1): 126-135. Recuperado de http://pepsic.bvsalud.org/pdf/epp/v8n1/v8n1a14.pdf

Chemama, R. (1995). Dicionário de psicanálise. Porto Alegre: Artes Médicas Sul.

Costa, M. L. \& Ferreira, R. (2019). Não há neurose sem corpo: um estudo sobre o lugar do corpo na histeria e na neurose obsessiva. Ágora, 22(2): 254-261. http://dx.doi.org/10.1590/1809-44142019002013

Cukiert, M. \& Priszkulnik, L. (2002). Considerações sobre o eu e o corpo em Lacan. Estudos de Psicologia, 7(1): 143-149. Recuperado de https://www.scielo.br/j/epsic/a/B6bDhRYBMtzmhTs6m4tW4rd

David-Ménard, M. (2000). A histérica entre Freud e Lacan. São Paulo: Escuta.

Elia, L. (1995). Corpo e sexualidade em Freud e Lacan. Rio de Janeiro: Uapê.

Fortes, M. I. A. (2008). Adolescência e o corpo: considerações sobre a anorexia. In M. R. Cardoso \& F. Marty (Orgs.), Destinos da adolescência (pp. 139151). Rio de Janeiro: 7letras.

Freud, S. (1996a). Algumas considerações para um estudo comparativo das paralisias motoras orgânicas e histéricas. In S. Freud, Publicações prépsicanalíticas e esboços inéditos (1886-1889)(Edição standard brasileira das obras psicológicas completas de Sigmund Freud, v. 1, pp. 197-216). Rio de Janeiro: Imago. (Trabalho original publicado em 1893).

Freud, S. (1996b). Extratos dos documentos dirigidos a Fliess - Rascunho K. As neuroses de defesa (Um conto de fadas natalino)( $1^{\circ}$ de janeiro de 1896). In S. Freud, Publicações pré-psicanalíticas e esboços inéditos (1886-1889)(Edição 
standard brasileira das obras psicológicas completas de Sigmund Freud, v. 1, pp. 267-276). Rio de Janeiro: Imago. (Trabalho original escrito em 1896 e publicado em 1950).

Freud, S. (1996c). Extratos dos documentos dirigidos a Fliess - Carta 52 (6 de dezembro de 1896). In S. Freud, Publicações pré-psicanalíticas e esboços inéditos (1886-1889)(Edição standard brasileira das obras psicológicas completas de Sigmund Freud, v. 1, pp. 281-287). Rio de Janeiro: Imago. (Trabalho original escrito em 1896 e publicado em 1950).

Freud, S. (1996d). Extratos dos documentos dirigidos a Fliess - Carta 59 (6 de abril de 1897). In S. Freud, Publicações pré-psicanalíticas e esboços inéditos (1886-1889)(Edição standard brasileira das obras psicológicas completas de Sigmund Freud, v. 1, p. 293). Rio de Janeiro: Imago. (Trabalho original escrito em 1897 e publicado em 1950).

Freud, S. (1996e). Extratos dos documentos dirigidos a Fliess - Rascunho L. Notas I (2 de maio de 1897). In S. Freud, Publicações pré-psicanalíticas e esboços inéditos (1886-1889)(Edição standard brasileira das obras psicológicas completas de Sigmund Freud, v. 1, pp. 297-300). Rio de Janeiro: Imago. (Trabalho original escrito em 1897 e publicado em 1950).

Freud, S. (1996f). Extratos dos documentos dirigidos a Fliess - Carta 69 (21 de setembro de 1897). In S. Freud, Publicações pré-psicanalíticas e esboços inéditos (1886-1889)(Edição standard brasileira das obras psicológicas completas de Sigmund Freud, v. 1, pp. 309-311). Rio de Janeiro: Imago. (Trabalho original escrito em 1897 e publicado em 1950).

Freud, S. (1996g). Extratos dos documentos dirigidos a Fliess - Carta 71 (15 de outubro de 1897). In S. Freud, Publicações pré-psicanalíticas e esboços inéditos (1886-1889)(Edição standard brasileira das obras psicológicas completas de Sigmund Freud, v. 1, pp. 314-317). Rio de Janeiro: Imago. (Trabalho original escrito em 1897 e publicado em 1950).

Freud, S. (1996h). Projeto para uma psicologia científica. In S. Freud, Publicações pré-psicanalíticas e esboços inéditos (1886-1889)(Edição standard brasileira das obras psicológicas completas de Sigmund Freud, v. 1, pp. 385-529). Rio de Janeiro: Imago. (Trabalho original escrito em 1895 e publicado em 1950).

Freud, S. (1996i). As neuropsicoses de defesa. In S. Freud, Primeiras publicações psicanalíticas (1893-1899)(Edição standard brasileira das obras psicológicas completas de Sigmund Freud, v. 3, pp. 49-72). Rio de Janeiro: Imago. (Trabalho original publicado em 1894).

Freud, S. (1996j). A hereditariedade e a etiologia das neuroses. In S. Freud, Primeiras publicações psicanalíticas (1893-1899)(Edição standard brasileira das obras psicológicas completas de Sigmund Freud, v. 3, pp. 139-155). Rio de Janeiro: Imago. (Trabalho original publicado em 1896). 
Freud, S. (1996k). Observações adicionais sobre as neuropsicoses de defesa. In S. Freud, Primeiras publicações psicanalíticas (1893-1899)(Edição standard brasileira das obras psicológicas completas de Sigmund Freud, v. 3, pp. 157183). Rio de Janeiro: Imago. (Trabalho original publicado em 1896).

Freud, S. (19961). A interpretação dos sonhos (I)(1900)(Edição standard brasileira das obras psicológicas completas de Sigmund Freud, v. 4). Rio de Janeiro: Imago. (Trabalho original publicado em 1900).

Freud, S. (1996m). Três ensaios sobre a teoria da sexualidade. In S. Freud, Um caso de histeria, três ensaios sobre sexualidade e outros trabalhos (19011905)(Edição standard brasileira das obras psicológicas completas de Sigmund Freud, v. 7, pp. 117-231). Rio de Janeiro: Imago. (Trabalho original publicado em 1905).

Freud, S. (1996n). Fantasias histéricas e sua relação com a bissexualidade. In S. Freud, "Gradiva" de Jensen e outros trabalhos (1906-1908)(Edição standard brasileira das obras psicológicas completas de Sigmund Freud, v. 9, pp. 145154). Rio de Janeiro: Imago. (Trabalho original publicado em 1908).

Freud, S. (1996o). Algumas observações gerais sobre ataques histéricos. In S. Freud, "Gradiva" de Jensen e outros trabalhos (1906-1908)(Edição standard brasileira das obras psicológicas completas de Sigmund Freud, v. 9, pp. 205213). Rio de Janeiro: Imago. (Trabalho original escrito em 1908 e publicado em 1909).

Freud, S. (1996p). A história do movimento psicanalítico. In S. Freud, A história do movimento psicanalítico, artigos sobre metapsicologia e outros trabalhos (1914-1916)(Edição standard brasileira das obras psicológicas completas de Sigmund Freud, v. 14, pp. 13-73). Rio de Janeiro: Imago. (Trabalho original publicado em 1914).

Freud, S. (1996q). Esboço de psicanálise. In S. Freud, Moisés e o monoteísmo, esboço de psicanálise e outros trabalhos (1937-1939)(Edição standard brasileira das obras psicológicas completas de Sigmund Freud, v. 23, pp. 151221). Rio de Janeiro: Imago. (Trabalho original escrito em 1938 e publicado em 1940).

Freud, S. (2010a). Introdução ao narcisismo. In S. Freud, Introdução ao narcisismo, ensaios de metapsicologia e outros textos (1914-1916)(Obras completas, P. C. Souza, trad., v. 12, pp. 13-50). São Paulo: Companhia das Letras. (Trabalho original publicado em 1914).

Freud, S. (2010b). Os instintos e seus destinos. In S. Freud, Introdução ao narcisismo: ensaios de metapsicologia e outros textos (1914-1916)(Obras completas, P. C. Souza, trad., v. 12, pp. 51-81). São Paulo: Companhia das Letras. (Trabalho original publicado em 1915)

Freud, S. (2010c). Novas conferências introdutórias à psicanálise: 33. A feminilidade. In S. Freud, O mal-estar na civilização, novas conferências 
introdutórias à psicanálise e outros textos (1930-1936)(Obras completas, P. C. Souza, trad., v. 18, pp. 263-293). São Paulo: Companhia das Letras. (Trabalho original publicado em 1933).

Freud, S. (2010d). Sobre a sexualidade feminina. In S. Freud, O mal-estar na civilização, novas conferências introdutórias à psicanálise e outros textos (1930-1936)(Obras completas, P. C. Souza, trad., v. 18, pp. 371-398). São Paulo: Companhia das Letras. (Trabalho original publicado em 1931).

Freud, S. (2011a). Sobre a psicogênese de um caso de homossexualidade feminina. In S. Freud, Psicologia das massas e análise do eu e outros textos (1920-1923)(Obras completas, P. C. Souza, trad., v. 15, pp. 114-149). São Paulo: Companhia das Letras. (Trabalho original publicado em 1920).

Freud, S. (2011b). Uma neurose do século XVII envolvendo o demônio. In S. Freud, Psicologia das massas e análise do eu e outros textos (19201923)(Obras completas, P. C. Souza, trad., v. 15, pp. 225-272). São Paulo: Companhia das Letras. (Trabalho original publicado em 1923).

Freud, S. (2011c). O eu e o id. In S. Freud, O eu e o id, "autobiografia" e outros textos (1923-1925)(Obras completas, P. C. Souza, trad., v. 16, pp. 13-74). São Paulo: Companhia das Letras. (Trabalho original publicado em 1923).

Freud, S. (2011d). A organização genital infantil. In S. Freud, $O$ eu $e o i d$, "autobiografia" e outros textos (1923-1925)(Obras completas, P. C. Souza, trad., v. 16, pp. 168-175). São Paulo: Companhia das Letras. (Trabalho original publicado em 1923).

Freud, S. (2011e). A dissolução do complexo de Édipo. In S. Freud, O eu e o id, "autobiografia" e outros textos (1923-1925)(Obras completas, P. C. Souza, trad., v. 16, pp. 203-213). São Paulo: Companhia das Letras. (Trabalho original publicado em 1924).

Freud, S. (2011f). Algumas consequências psíquicas da diferença anatômica entre os sexos. In S. Freud, O eu e o id, "autobiografia" e outros textos (19231925)(Obras completas, P. C. Souza, trad., v. 16, pp. 283-299). São Paulo: Companhia das Letras. (Trabalho original publicado em 1925).

Freud, S. (2013). Concepção psicanalítica da perturbação psicogênica da visão. In S. Freud, Observações sobre um caso de neurose obsessiva ["O homem dos ratos"], uma recordação de infância de Leonardo da Vinci e outros textos (1909-1910)(Obras completas, P. C. Souza, trad., v. 9, pp. 313-323). São Paulo: Companhia das Letras. (Trabalho original publicado em 1910)

Freud, S. (2014). A questão da análise leiga: diálogo com um interlocutor imparcial. In S. Freud, Inibição, sintoma e angústia, o futuro de uma ilusão e outros textos (1926-1929)(Obras completas, P. C. Souza, trad., v. 17, pp. 124230). São Paulo: Companhia das Letras. (Trabalho original publicado em 1926) 
Freud, S. (2016). Análise fragmentária de uma histeria ("O caso Dora”). In S. Freud, Três ensaios sobre a teoria da sexualidade, análise fragmentária de uma histeria ("O caso Dora") e outros textos (1901-1905)(Obras completas, P. C. Souza, trad., v. 6, pp. 173-320). São Paulo: Companhia das Letras. (Trabalho original escrito em 1901 e publicado em 1905)

Freud, S. (2018). Análise terminável e interminável. In S. Freud, Moisés e o monoteísmo, compêndio de psicanálise e outros textos (1937-1939)(Obras completas, P. C. Souza, trad., v. 19, pp. 274-326). São Paulo: Companhia das Letras. (Trabalho original publicado em 1937).

Galesi, Z. A. (2012). De Freud a Lacan: um passo de saber sobre as mulheres! Opção lacaniana online, 3(8): 1-9. Recuperado de http://www.opcaolacaniana.com.br/pdf/numero_8/De_Freud_Lacan.pdf

Garcia-Roza, L. A. (1985). Freud e o inconsciente. Rio de Janeiro: Zahar.

Garcia-Roza, L. A. (2008). Introdução à metapsicologia freudiana 3: artigos de metapsicologia. Rio de Janeiro: Jorge Zahar.

Holanda, C. B. \& Lobo, E. (1983). Beatriz. O grande circo místico. Rio de Janeiro: Som Livre.

Jorge, M. A. C. (2005). As bases conceituais (Fundamentos da psicanálise de Freud a Lacan, v. 1). Rio de Janeiro: Zahar.

Kaufmann, P. (1996). Dicionário enciclopédico de psicanálise: o legado de Freud e Lacan. Rio de Janeiro: Zahar.

Kehl, M. R. (1998). Deslocamentos do feminino: a mulher freudiana na passagem para a modernidade. Rio de Janeiro: Imago.

Lacan, J. (1988). As psicoses (O seminário, v. 3). Rio de Janeiro: Zahar. (Trabalho original publicado em 1955 e 1956).

Lacan, J. (1992a). A transferência (O seminário, v. 8). Rio de Janeiro: Zahar. (Trabalho original publicado em 1960 e 1961).

Lacan, J. (1992b). O avesso da psicanálise (O seminário, v. 17). Rio de Janeiro: Zahar. (Trabalho original publicado em 1969 e 1970).

Lacan, J. (1995). A relação de objeto (O seminário, v. 4). Rio de Janeiro: Zahar. (Trabalho original publicado em 1956 e 1957).

Lacan, J. (1998a). O estádio do espelho como formador da função do eu tal como nos é revelado na experiência psicanalítica. In J. Lacan, Escritos (pp. 96-103). Rio de Janeiro: Jorge Zahar. (Trabalho original publicado em 1949).

Lacan, J. (1998b). Intervenção sobre a transferência. In J. Lacan, Escritos (pp. 214-225). Rio de Janeiro: Jorge Zahar. (Trabalho original publicado em 1951). 
Lacan, J. (1998c). Função e campo da fala e da linguagem em psicanálise. In J. Lacan, Escritos (pp. 238-324). Rio de Janeiro: Jorge Zahar. (Trabalho original publicado em 1953).

Lacan, J. (1998d). A psicanálise e seu ensino. In J. Lacan, Escritos (pp. 438-460). Rio de Janeiro: Jorge Zahar. (Trabalho original publicado em 1957).

Lacan, J. (1998e). A significação do falo. In J. Lacan, Escritos (pp. 692-703). Rio de Janeiro: Jorge Zahar. (Trabalho original publicado em 1958).

Lacan, J. (1999). As formações do inconsciente (O seminário, v. 5). Rio de Janeiro: Zahar. (Trabalho original publicado em 1957 e 1958).

Lacan, J. (2002). O desejo e sua interpretação (O seminário, v. 6). Rio Grande do Sul: Associação Psicanalítica de Porto Alegre. (Trabalho original publicado em 1958 e 1959).

Lacan, J. (2007). O sinthoma (O seminário, v. 23). Rio de Janeiro: Zahar. (Trabalho original publicado em 1975 e 1976).

Lacan, J. (2008a). Os quatro conceitos fundamentais da psicanálise (O seminário, v. 11). Rio de Janeiro: Zahar. (Trabalho original publicado em 1964).

Lacan, J. (2008b). Mais, ainda (O seminário, v. 20). Rio de Janeiro: Zahar. (Trabalho original publicado em 1972 e 1973).

Lacan, J. (2010). O eu na teoria de Freud e na técnica da psicanálise (O seminário, v. 2). Rio de Janeiro: Zahar. (Trabalho original publicado em $1954 \mathrm{e}$ 1955).

Laplanche, J. \& Pontalis, J.-B. (1992). Vocabulário de Psicanálise. São Paulo: Martins Fontes. (Trabalho original publicado em 1967).

Laznik, M.-C. (2008). Breve relato das ideias de Lacan sobre a histeria. Reverso, 30(55): 15-34. Recuperado de http://pepsic.bvsalud.org/pdf/reverso/v30n55/v30n55a02.pdf

Lazzarini, E. \& Viana, T. C. (2006). O corpo em psicanálise. Psicologia: teoria e pesquisa, 22(2): 241-250. Recuperado de http://www.scielo.br/pdf/ptp/v22n2/a14v22n2.pdf

Lispector, C. (1998). Água viva. Rio de Janeiro: Rocco. (Trabalho original publicado em 1973)

Nasio, J.-D. (1991). A histeria: teoria e clínica psicanalítica. Rio de Janeiro: Jorge Zahar.

Naves, E. (2007). Para além do desejo: um estudo sobre histeria e pulsão de morte. (Tese de Doutorado). Universidade de Brasília, Brasília, DF. 
Pollo, V. (2016). Mulheres histéricas. Rio de Janeiro: Contra Capa.

Prado, I. B. B. (2000). Contornos originais do corpo. Escola Letra Freudiana, 27, 61-64.

Quinet, A. (2005). A lição de Charcot. Rio de Janeiro: Jorge Zahar.

Rilke, R. M. (1966). Torso arcaico de Apolo ["Archaïscher Torso Apollos"]. In M. Bandeira, Estrela da vida inteira. Rio de Janeiro: José Olympio. (Trabalho original publicado em 1926)

Riviere, J. (2005). A feminilidade como máscara. Psychê, 9(16): 13-24. (Trabalho original publicado em 1929). Recuperado de http://pepsic.bvsalud.org/pdf/psyche/v9n16/v9n16a02.pdf

Rudge, A. M. (1998). Pulsão e linguagem: esboço de uma concepção psicanalítica do ato. Rio de Janeiro: Jorge Zahar.

Rudge, A. M. (2009). Trauma. Rio de Janeiro: Jorge Zahar.

Salgado, M. (2008). Mulher: dor ou delícia de ser o que é? Acto falho. Recuperado de http://www.sedes.org.br/Departamentos/Formacao_Psicanalise/site/wpcontent/uploads/2015/01/10-ACTO-FALHO-MAIO-20082.pdf

Saggese, E. (2001). Adolescência e psicose: transformações sociais e os desafios da clínica. Rio de Janeiro: Companhia de Freud.

Silva, A. \& Santos, K. (2017). O feminino e a perspectiva lacaniana de superação da lógica fálica. Reverso, 39(74): 39-46. Recuperado de http://pepsic.bvsalud.org/pdf/reverso/v39n74/v39n74a05.pdf

Silva, D. Q. \& Folberg, M. N. (2008). De Freud a Lacan: as ideias sobre a feminilidade e a sexualidade feminina. Estudos de Psicanálise, 31: 50-58. Recuperado de http://pepsic.bvsalud.org/pdf/ep/n31/n31a07.pdf

Silva, H. C. \& Rey, S. (2011). A beleza e a feminilidade: um olhar psicanalítico. Psicologia: ciência e profissão, 31(3): p. 554-567. doi: 10.1590/S141498932011000300009

Simone, N. (1968). Ain't got no, I got life. 'Nuff Said! [CD]. Nova York: RCA Victor.

Teixeira, A. (2010). O sonho da dessuposição de Fliess. $O$ almanaque online, 6. Recuperado de http://almanaquepsicanalise.com.br/wpcontent/uploads/2015/09/antonio.pdf

Tolipan, E. (1992). Dora e a questão da mulher. In C. S. Katz (Org.), A histeria, o caso Dora: Freud, Melanie Klein, Lacan (pp. 185-195). Rio de Janeiro: Imago. 
Valdivia, O. (1997). Psicanálise e feminilidade: algumas considerações. Psicologia: Ciência e Profissão, 17(3): 1-10. doi: 10.1590/S141498931997000300004

Winograd, M. \& Mendes, L. (2009). Qual corpo para a psicanálise? Breve ensaio sobre o problema do corpo na obra de Freud. Psicologia: teoria e prática, 11(2): 211-223. Recuperado de http://pepsic.bvsalud.org/pdf/ptp/v11n2/v11n2a15.pdf

Zalcberg, M. (2012). A evastação: uma singularidade feminina. Tempo psicanalítico, 44(2): 469-475. $\quad$ Recuperado de http://pepsic.bvsalud.org/pdf/tpsi/v44n2/v44n2a13.pdf 